\title{
AÇÃO DA COBERTURA COM LEGUMINOSAS SOBRE O SOLO E O SERINGAL EM FORMAÇÃO
}

MILENE MOREIRA DA SILVA ROSA DE SOUZA

- Engenheira Agrônoma -

Orientador: Prof. Dr. JOSÉ DIAS COSTA

Dissertação apresentada à Escola Superior de Agricultura "Luiz de Queiroz", da Universidade de São Paulo, para obtenção do Título de Mestre em Agronomia, Área de Concentração: Fitotecnia.

PIRACICABA

Estado de São Paulo - Brasil

Julho de 1996 
Dados Internacionais de Catalogação na Publicação (CIP) DIVISÃO DE BIBLIOTECA E DOCUMENTAÇÃO - Campus "Luiz de Queiroz"/USP

Souza, Milene Moreira da Silva Rosa de

Ação da cobertura com leguminosas sobre o solo e o seringal em forma ção / Milene Moreira da Silva Rosa. - - Piracicaba, 1996.

88p. : il.

Dissertação (mestrado) - Escola Superior de Agricultura Luiz de Queiroz, 1996.

Bibliografia.

1. Cobertura morta 2. Leguminosa como cobertura - Efeito 3. Nitrogêno em seringueira - Teor 4. Seringueira - Adubação verde. I. Titulo.

CDD 633.895 


\section{AÇÃO DA COBERTURA COM LEGUMINOSAS SOBRE O SOLO E O SERINGAL EM FORMAÇÃO}

Milene Moreira da Silva Rosa de Souza

Aprovada em: 28 / 08 / 96.

Comissão julgadora:

Prof. Dr. José Dias Costa ESALQ / USP

Prof. Dr. Salim Simão ESALQ / USP

Prof. Dra . Siu Miu Tsai CENA / USP

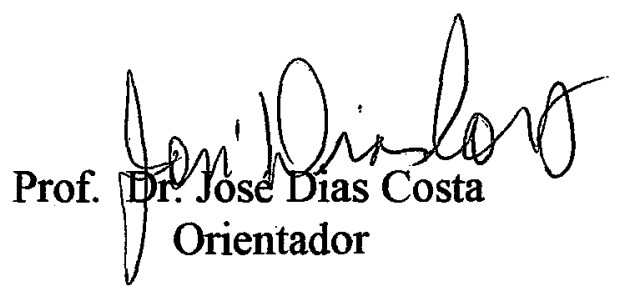




\section{AGRADEÇO}

A DEUS, por estar sempre presente em minha vida;

Aos meus avós, especialmente ao meu avô Antônio (in memorian)

e avó Maria por me ensinarem a amar e respeitar a natureza;

Aos meus pais, Carlos (in memorian) e Iraci por minha

formação moral e profissional.

\section{DEDICO}

Ao meu marido José pelo incentivo constante e a minha filha Giovanna pela sua presença e alegria a qual me deram forças para vencer mais essa importante etapa. 


\section{AGRADECIMENTOS}

Ao orientador Prof. Dr. José Dias Costa pelo constante incentivo, orientação e amizade e a quem devo este trabalho;

A Prof. Dra Siu Miu Tsai, do CENA pelo apoio e sugestões;

Ao Prof. Dr. Salim Simão pela amizade e apoio principalmente nos momentos difíceis;

Ao Prof. Dr. Luiz Roberto Angelocci pelo valioso empréstimo dos geotermomêtros;

Ao Dr. Paulo de Souza Gonçalves, IAC e Prof. Dr. Antônio Natal Gonçalves (Dept ${ }^{\circ}$ de Ciências Florestais da ESALQ) pelas sugestões e valiosa contribuição em materiais bibliográficos;

Ao Eng ${ }^{\circ}$. Agr ${ }^{\circ}$. Clineu Domingos Di Pietro, pelo seu profissionalismo, amizade e incentivo durante toda a minha formação profissional;

Ao Prof. Dr. Roberto Antônio Arévalo, IAC pelo apoio constante e amizade;

Ao Conselho Nacional de Desenvolvimento Científico e Tecnológico $(\mathrm{CNPq})$, pela concessão da bolsa de estudos;

A Sementes Piraí , pela doação das sementes de mucuna-preta;

A todos funcionários e estagiários de departamento de Agricultura da ESALQ, especialmente ao Sr. Celestino Alves Ferreira, Wilson Góes da Silva e ao Técnico Agrícola Marcelo Valente Batista, pelo empenho nos trabalhos de campo; 
Aos funcionários Francisco Carlos Montrazi e Odair Bastos de Almeida (in memorian) do Laboratório de Microbiologia do CENA, pelo apoio na realização das análises de nitrogênio;

Aos colegas de pós-graduação: Alcebíades São José, Adriana Novais Martins, Elir de Oliveira, Elaine Bahia Wutke , Gaspar de Los Reyes Gonzalez e Luiz A. Biasi;

Ao CCIN- "Centro de Convivência Infantil" pelo cuidado, carinho e grande contribuição na formação e educação da minha filha Giovanna;

A todos aqueles que direta ou indiretamente contribuíram para a realização deste trabalho. 


\section{SUMÁRIO}

Página

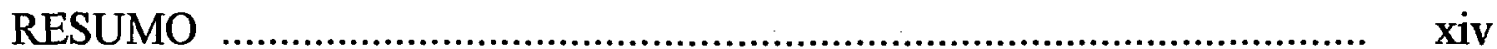

SUMMARY …............................................................................. xvi

1. INTRODUÇÃO …............................................................ 1

2. REVISÃO DE LITERATURA ........................................... 2

2.1. Origem e distribuição da seringueira (........................... 2

2.2. ..História, situação atual e perspectivas ........................ 3

2.3. Os fatores climáticos ….......................................... $\quad 5$

2.4. O uso de cobertura vegetal ........................................ 6

2.5. Disponibilidade e fixação de nitrogênio pelas leguminosas.

2.6. Influência da temperatura ......................................... 12

3. MATERIAL E MÉTODOS

3.1. Cultivar de seringueira

3.2. Éspécies de leguminosas

3.3. Solo e análise química e física..................................... 20

3.4. Instalação e condução do experimento ………............... 21

3.5. Análise estatística .................................................. 24

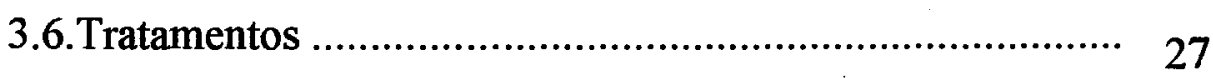

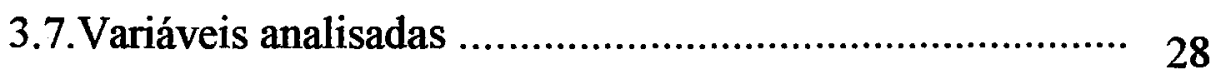


3.7.1. Temperatura do solo.............................................. 28

3.7.2. Nitrogênio mineral do solo e planta ........................ 30

3.7.2.1. Determinação do nitrogênio mineral ...................... 30

3.7.2.2. Análise do $\mathrm{N}-$ mineral do solo e planta .................. $\quad 30$

3.7.3. Determinação da umidade do solo ............................ 32

4. RESULTADOS E DISCUSSÃO ........................................ 33

4.1.Teor de nitrogênio mineral do solo .............................. 33

4.2. Teor da umidade no solo.......................................... 41

4.3. Teor de nitrogênio nas plantas de seringueira ............... 47

4.4. Temperatura mínima e máxima do solo ....................... 49

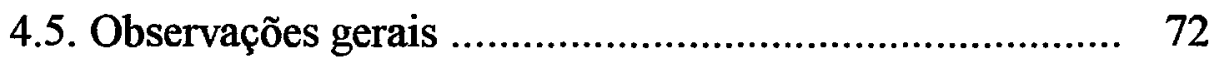

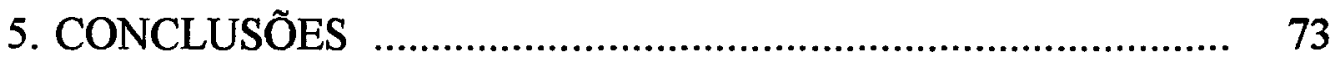

REFERÊNCIAS BIBLIOGRÁFICAS ................................... 74 


\section{LISTA DE TABELAS}

Tabela 1. Quantidade total de nutrientes retornados ao solo através de diferentes coberturas vegetais, durante cinco anos de imaturidade do seringal

Tabela 2. Temperatura do solo registrada as $15 \mathrm{hs}$ de $25 / 12 / 90$ (IAPAR-Palotina).

Tabela 3. Dados climáticos (médias mensais) da região de Piracicaba, SP

Tabela 4. Resultados da análise química do solo da área do experimento.......

Tabela 5. Características físicas do solo da área experimental

Tabela 6. Resultados da análise química das plantas de seringueira (inicial)

Tabela 7. Estrutura da análise da variância

Tabela 8. Notação dos tratamentos.

Tabela 9. Notação das épocas de coletas de dados

Tabela 10. Análise da variância e teste $\mathrm{F}$ para os dados teor de $\mathbf{n}$ mineral do solo.

Tabela 11. Comparação de médias de nitrogênio no solo em relação aos tratamentos

Tabela 12. Médias do efeito do nitrogênio em relação a profundidade, por um período de 8 meses 
Tabela 13. Comparação das médias de nitrogênio do solo segundo épocas ...

Tabela 14. Análise da variância e teste $\mathrm{F}$ para os dados de determinação .da \% de umidade no solo

Tabela 15. Comparação das médias da \% de umidade do solo segundo os tratamentos

Tabela 16. Comparação da médias da \% de umidade do solo segundo profundidades

Tabela 17. Comparação das médias da umidade do solo segundo épocas.

Tabela 18. Análise da variância para o teor de nitrogênio inicial da planta de seringueira

Tabela 19. Comparação de médias do nitrogênio inicial da plantas de seringueira

Tabela 20. Análise da variância para o nitrogênio final das plantas da seringueira

Tabela 21. Comparação das médias do teor de nitrogênio das plantas de seringueira

Tabela 22. Análise da variância e teste $\mathrm{F}$ para os dados de temperatura mínima do solo

Tabela 23. Comparação de médias da temperatura mínima do solo segundo os tratamentos 
segundo as profundidade.

Tabela 25. Comparação das médias da temperatura mínima do solo em relação as épocas

Tabela 26. Análise da variância e teste $\mathrm{F}$ para os dados de temperatura máxima do solo.

Tabela 27. Comparação de médias de temperatura máxima do solo segundo os tratamentos

Tabela 28. Comparação de médias das temperaturas máximas do solo segundo as profundidades

Tabela 29. Comparação das médias da temperatura máxima do solo em relação aos tratamentos segundo as épocas

Tabela 30. Dados da temperatura mínima e máxima do solo para o tratamento guandu ( cobertura permanente), durante os 8 períodos

Tabela 31. Dados da temperatura mínima e máxima do solo para o tratamento testemunha (solo $\mathrm{nu}$ ), durante os $\mathbf{8}$ períodos

Tabela 32. Dados da temperatura mínima e máxima do solo para o tratamento CMG (cobertura morta de guandu),durante os 8 períodos

Tabela 33. Dados da temperatura mínima e máxima do solo para o tratamento CMM (cobertura morta de Mucuna-preta),durante os 8 períodos 


\section{LISTA DE FIGURAS}

Figura 1. Aspectos gerais do experimento

Figura 2. Evolução das médias do nitrogênio mineral do solo, nos tratamentos. Médias dos 8 períodos

Figura 3. Disponibilidade do nitrogênio mineral do solo nos tratamentos em relação a profundidades Médias dos 8 períodos

Figura 4. Disponibilidade do nitrogênio mineral nos tratamentos em relação as épocas de amostragens. Médias dos 8 períodos

Figura.5. Evolução das médias da \% de umidade segundo os tratamentos.....

Figura 6. Evolução das médias da \% de umidade nos tratamentos segundo as profundidades

Figura 7. Evolução das médias da \% de umidade do solo nos tratamentos. segundo as épocas

Figura 8. Evolução das médias da temperatura mínima do solo segundo os .tratamento

Figura 9. Evolução das médias da temperatura mínima do solo segundo as profundidades

Figura 10. Evolução das médias da temperatura mínima do solo segundo interação tratamento $\mathrm{x}$ profundidade

Figura 11. Comparação das médias da temperatura mínima do solo segundo interação profundidade $\mathrm{x}$ época.

Figura 12. Evolução das médias das temperatura máximas do solo em 
relação aos tratamentos

Figura 13. Evolução das médias das temperaturas máximas do solo em relação aos tratamentos segundo as diferentes profundidades

Figura 14. Evolução das médias da temperaturas máximas do solo em relação aos tratamentos segundo as épocas

Figura 15. Evolução das médias da temperaturas máximas do solo em relação as profundidades segundo as épocas

Figura 16 Evolução das temperaturas mínimas do solo nas diferentes profundidades para o tratamento guandu (guandu permanente), durante os 8 períodos

Figura 17. Evolução das temperaturas máximas do solo nas diferentes profundidades para o tratamento guandu (guandu permanente), durante os 8 períodos

Figura 18. Evolução das temperaturas mínimas do solo nas diferentes profundidades para o tratamento Testemunha (solo nu), durante os 8 períodos

Figura 19. Evolução das temperaturas máximas do solo nas diferentes profundidades para o tratamento Testemunha (solo nu), durante os 8 períodos

Figura 20. Evolução das temperaturas mínimas do solo nas diferentes profundidades para o tratamento $\mathrm{CMG}$ (cobertura morta de guandu), durante os 8 períodos

Figura 21. Evolução das temperaturas máximas do solo nas diferentes profundidades para o tratamento $\mathrm{CMG}$ (cobertura morta de 
guandu), durante os 8 períodos

68

Figura 2. Evolução das temperaturas mínima do solo nas diferentes profundidades para o tratamento $\mathrm{CMM}$ (cobertura morta de mucuna-preta),durante os $\mathbf{8}$ períodos 70

Figura 23. Evolução das temperaturas máximas do solo nas diferentes profundidades para o tratamento CMM(cobertura morta de mucuna-preta), durante os 8 períodos 


\title{
AÇÃO DA COBERTURA COM LEGUMINOSAS SOBRE O SOLO E O SERINGAL EM FORMAÇÃO
}

\author{
Autor: Milene Moreira da Silva Rosa de Souza \\ Orientador: Prof. Dr. José Dias Costa
}

\section{Resumo}

Com o objetivo de conhecer o efeito da cobertura do solo dentro de um seringal em formação foram utilizadas duas leguminosas o guandu (Cajanus cajan (L) Millps ) e a mucuna-preta (Mucuna aterrima Merr.), como cobertura permanente e cobertura morta, determinando-se a temperatura, o teor de umidade e o nitrogênio do solo e o teor de nitrogênio nas plantas de seringueira. $O$ experimento foi conduzido durante o período de fevereiro de 1995 a fevereiro de 1996. O delineamento experimental empregado foi de parcelas subdivididas, utilizando 4 tratamentos e 4 repetições, para obtenção de dados referentes ao teor de nitrogênio e umidade do solo, teor de nitrogênio nas plantas de seringueira, temperatura mínima e máxima do solo. Os tratamentos foram os seguintes: guandu (cobertura permanente), guandu (cobertura morta), mucuna-preta (cobertura morta) e testemunha (solo $\mathrm{nu}$ ).Com base nos resultados obtidos, concluímos: $\mathrm{O}$ emprego da cobertura permanente de guandu evita a erosão e o aquecimento excessivo do solo. $\mathrm{O}$ emprego da cobertura permanente de guandu reduz o nitrogênio mineral e o teor de água a $10 \mathrm{~cm}$ de profundidade do solo. A cobertura morta de mucuna-preta mantém o mesmo valor de nitrogênio mineral no 
solo, evita a erosão e o aquecimento excessivo do solo. A cobertura morta de mucuna-preta reduz o teor de umidade nas duas profundidades do solo (10 e a 30 $\mathrm{cm})$. 


\section{EFFECT OF LEGUMINOSAE CROP AND MULCHING ON THE SOIL PROPERTIES AND ON THE PERFORMANCE OF YOUNG RUBBER TREES.}

Author: Milene Moreira da Silva Rosa de Souza

Adviser: Prof. Dr. José Dias Costa

\section{SUMMARY}

The present study had the objective of determining the effect of the soil cover by two leguminosae species, used as cover crop or mulching, on the growth and performance of young rubber trees (Hevea brasiliensis) in southern Brazil (Piracicaba, São Paulo State).

The experiment was carried out from February 1995 through February 1996. The statistical design selected for the study was the split-plot, with 4 treatments and 4 replications. The data collected included soil moisture, maximum and minimum soil temperatures, soil and foliar $\mathrm{N}$ contents.

The treatments were the following: guandu (Cajanus cajan (L) Millsp) (crop), guandu (mulching), mucuna-preta (Mucuna aterrima Merr.) (mulching), and control ( uncovered soil).

The results allowed the followin conclusions: 1. Guandu used as a crop reduced soil temperature and protectedit against erosion. 2. Guandu used as a crop reduced soil mineral $\mathrm{N}$ and reduced soil moisture at the depth of $10 \mathrm{~cm}$. 
3. Mucuna-preta used as mulching kept the same concentration of mineral $\mathrm{N}$ in the soil and avoided high soil temperatures. 4. Mucuna-preta used as mulching reduced soil moisture at both soil depths ( 10 and $30 \mathrm{~cm}$ ) as well as soil erosion. 


\section{INTRODUÇÃo}

A seringueira ( Hevea brasiliensis Muell. Arg. ), pertence à família Euphorbiaceae, sua ocorrência natural vai da latitude $3^{\circ} \mathrm{N}$ a $15^{\circ} \mathrm{S}$ ( mais de 4 milhões de $\mathrm{Km}^{2}$ ), mas, comercialmente, as regiões de produção vão desde a latitude $24^{\circ} \mathrm{N}$ na China até $25^{\circ} \mathrm{S}$ no litoral do Estado de São Paulo, conforme Ortolani ( 1986).

O Planalto Paulista, segundo Cardoso (1973), Medrado \& Costa (1990), é viável para heveicultura comercial.

E graças aos esforços desenvolvidos por empresários, instituições de pesquisa e extensão rural, a cultura da seringueira se expandiu rapidamente pelo Estado de São Paulo, destacando a década dos anos 80 como a mais importante em termos de expansão de área plantada. Sendo hoje o Estado de São Paulo o maior produtor de borracha natural do País.

A cultura da seringueira pode promover a recuperação dos solos degradados desde que convenientemente manejados além de fixar o homem à terra, cumprindo desta forma, finalidades sociais, ecológicas e econômicas. Ressalta-se que a cultura da seringueira é viável para grandes, médias e pequenas empresas. 
A adubação verde possibilita recuperar a fertilidade do solo proporcionando aumento de matéria orgânica, CTC e disponibilidade de micronutrientes; formação e estabilização de agregados; melhoria das condições para infiltração de água e aeração; diminuição da amplitude de variação térmica; controle de nematóides e, fornecimento de nitrogênio obtido da fixação biológica, (Igue, 1984).

O presente trabalho tem por objetivo avaliar o efeito da cobertura do solo na temperatura, umidade, teor de nitrogênio no solo e na planta da seringueira.

\section{REVISÃO DE LITERATURA}

\subsection{Origem e distribuição da seringueira}

O gênero Hevea pertence à família Euphorbiaceae, onde encontramos 10 espécies, sendo que a Hevea brasiliensis é a mais plantada comercialmente, objetivando a produção de borracha natural.

Segundo Wycherley ${ }^{1}$ citado por Colombo et al.,(1989), e Conforto (1995), o centro primário de diversidade genética do gênero é a região do Rio Negro, na confluência com o Rio Amazonas, onde são encontradas sete espécies ( $H$. benthamiana Muell. Arg.; H. guianensis Aub.; H. microphylla Ule; H. nitida

1 Wycherley, P.R. Rubber. In: SIMMONDS, N.W., ed. Evolution of crop plants. Edinburg: Congman, 1976. P. 77-81. 
Mart. ex. Muell. Arg.; H. pauciflora (Spr ex Bth) Muell. Arg.; H. rigidifolia ( Spr ex Bth) Muell. Arg. e H. spruceana (Bth) Muell. Arg.), existindo um centro secundário abrangendo uma vasta área nas proximidades do município do Borba, no Baixo Rio Madeira, onde se encontram cinco espécies naturais, dentre as quais H. brasiliensis ( Willd ex A. Juss.) Muell. Arg.

A importância dessa planta para o homem determinou sua expansão geográfica, abrangendo outras latitudes com agroclimas bem diferenciados das áreas de origem.

Atualmente a heveicultura comercial está compreendida entre latitudes de $22^{\circ} \mathrm{N}$ na China e $25^{\circ} \mathrm{S}$ no Brasil, onde a periodicidade e a amplitude dos fatores térmicos e hídricos alteram o comportamento fenológico dessa planta, e exigem como premissa básica, o desenvolvimento e adaptação de novas tecnologias de produção ( Ortolani, 1987).

\subsection{História, situação atual e perspectivas}

No final do século passado e no início desse século, o Brasil ocupava um lugar de destaque no mercado mundial da borracha, sendo responsável por cerca de $98 \%$ da produção (Bernardes et al., 1990). Atualmente o país produz menos que $1 \%$ da produção mundial e importa aproximadamente $71 \%$ do que consome (Anuário Estatístico do Mercado da Borracha, 1995).

A produção de borracha natural no Brasil, basicamente dependeu dos seringais nativos da floresta amazônica, somente a partir de 1990, os seringais de cultivo passaram a predominar com o aumento da quantidade de seringais formados, principalmente em São Paulo, Mato Grosso, Bahia e Espírito Santo, 
plantados na sua maioria através de investimentos privados. Em 1975, cerca de $88 \%$ da produção nacional de borracha natural era originária de seringais nativos. Esta participação que chegou a atingir $91 \%$ em 1977. A partir de 1986, começou a declinar de forma irreversível, caindo em 1992 para cerca de $35 \%$, enquanto a produção dos seringais cultivados alcançou $65 \%$.

Em 1992, São Paulo surge como principal produtor nacional com $27 \%$ de participação, seguido pela Bahia e Mato Grosso com $15 \%$ cada um. No período de 1985-93, o número de pés plantados e a área cultivada com seringueira em SP, cresceram $171 \%$, apresentando uma taxa média de crescimento de $13 \%$ ao ano. $\mathrm{O}$ aumento do número de pés em produção que era de $4 \%$ em 1985 , evolui para $29 \%$ em 1993, sendo este o fator principal que explica a evolução do estado para a posição de primeiro produtor nacional de borracha natural .

As perspectivas são favoráveis para o aumento da produção brasileira de borracha, uma vez que somente cerca de $50 \%$ dos seringais brasileiros estão em fase produtiva, além disso, o Brasil é um dos poucos países que dispõe de grandes áreas com condições ambientais favoráveis para expansão do seus plantios.

As áreas de cultivo no Planalto Paulista vem crescendo e tem-se observado que cerca de $90 \%$ das áreas de seringais jovens são deixados desprotegidos durante o período de formação, até que a copa das arvores se encontrem cobrindo desta forma toda área . È importante que seja dada alguma forma de proteção ao solo para evitar os efeitos deletéricos de chuvas torrenciais, temperaturas elevadas, etc., que contribuem para a degradação do solo.

O manejo inadequado do solo pode levar, com o passar do tempo, a sérias consequências, exaurindo-o de baixa fertilidade . Nos solos tropicais, susceptíveis a esse fenômeno, torna-se necessário o emprego de práticas que visem minimizar o problema (Mello \& Brasil Sobrinho, 1960). 


\subsection{Os fatores climáticos}

Zong Dao \& Xueqin ${ }^{2}$, citado por Ortolani (1987), relatam a influência da temperatura ambiente no crescimento da seringueira. Dois valores extremos para o desenvolvimento da seringueira são: sob temperatura de $40^{\circ} \mathrm{C}$, a taxa de respiração é maior que a taxa de fotossíntese e, à $10^{\circ} \mathrm{C}$, a fotossíntese é praticamente nula, podendo ser utilizada como ponto zero de crescimento.

Os mesmos autores citam que as temperaturas entre 27 a $30^{\circ} \mathrm{C}$ são mais favoráveis à fotossíntese. É possível que a faixa ótima de temperatura abranja o intervalo de 25 a $27^{\circ} \mathrm{C}$. Isso poderia explicar as elevadas taxas de crescimento observadas no Planalto Paulista, atingindo a idade de explotação entre o quinto e o sexto ano.

O crescimento da seringueira jovem é normalmente afetado por estresses, como: secas prolongadas, baixas temperaturas no inverno, alta temperatura e baixa umidade relativa, no verão, e alta altitude são fatores que afetam desfavoravelmente o crescimento segundo Sethuraj (1985).

Variações significativas quanto à resposta de clones à seca tem sido observadas . Irrigação e o sombreamento parcial das plantas jovens pode aliviar os efeitos adversos do estresse de umidade do solo e altas temperaturas, podendo ainda acelerar o seu desenvolvimento.

2 Zong Dao, H. \& Xueqin, Z. Rubber cultivation in China. In: Planter's Conference. Kuala Lumpur, 1983. Persidangan. 1983. 15p. 
Após o pleno desenvolvimento do sistema radicular, mesmo na juvenilidade, a seringueira demonstra boas condições de tolerância a períodos prolongados de estiagem. Em sua maturidade, com o aprofundamento das raízes, essa tolerância é mais elevada, como foi observado durante as secas de 1961, 1963 e 1985 no estado de São Paulo.

Em 1985, com deficiência hídrica anual de $400 \mathrm{~mm}$, uma das maiores ocorridas no século, foram verificadas pequenos decréscimos temporários de produção, irregularidade não significativa no reenfolhamento e necessidade de irrigação, para os seringais com idade de até um ano de campo (Ortolani, 1986).

Em 1994, houve duas geadas em junho e julho, seguidas por um longo período de seca. Esta situação se refletiu em todas as árvores do seringal da ESALQ $\backslash$ USP, em Piracicaba, SP, acarretando queda significativa na produção no ano agrícola de 1994\95. Ocorreram também secamento de alguns ramos dos ponteiros em muitas árvores ( Martins, 1995).

\section{4. $O$ uso de cobertura vegetal}

$O$ uso de cobertura vegetal nos seringais em formação, tem grande importância não só na manutenção da fertilidade, mas também na conservação do solo e recuperação dos solos. Nas duas últimas décadas, surgiram trabalhos sobre o efeito de diferentes coberturas vegetais no desenvolvimento e produção do seringal, destacando-se entre estes Watson et al.,(1964); Mainstone (1969); Pushparajah \& Chellapah (1969); Soong \& Yap(1976); Yogaratnam et al., (1977); Salgado et al.,(1984); Cardoso et al.,( 1988). Os resultados são animadores 
entretanto existe a necessidade de pesquisas nas regiões em expansão da cultura onde prevalecem condições climáticas diferentes das regiões tradicionais onde o número de pesquisas é razoável.

Quanto à reciclagem, tem-se observado incorporação no solo de quantidades relativamente altas de nutrientes através do uso de cobertura com leguminosas comparada com gramíneas ou vegetação nativa. Segundo Dolmat (1980), uma cobertura com leguminosas em pleno vigor nos cinco primeiros anos de plantio pode incorporar ao solo de 226 a $353 \mathrm{~kg}$ ha de nitrogênio, 18 a 27 kglha de fósforo, 85 a $131 \mathrm{~kg}$ ไha de potássio e 15 a $27 \mathrm{~kg}$ ha de magnésio, enquanto a cobertura vegetal de gramíneas ou vegetação nativa incorpora quantidades bem inferiores em relação à cobertura com leguminosas (Tabela 1).

Tabela 1. Quantidade total de nutrientes retornados ao solo através de diferentes coberturas vegetais, durante cinco anos de imaturidade do seringal.

\begin{tabular}{lrrrr}
\hline Plantas de cobertura & Nitrogênio & Fósforo & Potássio & Magnésio \\
& & & & \\
& & Kgไha & - & \\
\hline Leguminosas & $226-353$ & $18-27$ & $85-131$ & $15-27$ \\
Gramíneas & $24-65$ & $8-16$ & $31-86$ & $9-15$ \\
Vegetação nativa & $13-117$ & $3-10$ & $46-140$ & $3-18$ \\
\hline
\end{tabular}

Fonte: Dolmat (1980).

A maior disponibilidade desses nutrientes incorporados ao solo pela cobertura de leguminosas resultou em um crescimento mais rápido, contribuindo 
para uma maturidade precoce do seringal. Pushparajah \& Chellapah (1969), mostraram que, com a cobertura vegetal de leguminosas o período de imaturidade de um seringal poderá ser reduzido em dois anos comparado com a cobertura vegetal nativa. Segundo Chandapillay (1968), a concentração do crescimento das raízes nas camadas superiores do solo promove a competição com a seringueira por nutrientes. $\mathrm{O}$ autor informa todavia que estudos do "Rubber Research Institute of Malaysia" (1967), mostraram que com a aplicação adicional de fertilizantes compensa-se a competição.

$\mathrm{Na}$ realidade somente a partir do terceiro ano a diferença a favor da cobertura com leguminosas começa a aparecer, devido à decomposição e consequentemente liberação de nutrientes.

Haridas (1979) diz que a leguminosa deve retornar ao solo entre o terceiro e o quinto ano após o estabelecimento, o total de $300 \mathrm{~kg} / \mathrm{ha}$ de nitrogênio, equivalente a $1.500 \mathrm{~kg} / \mathrm{ha}$ de sulfato de amônio, isto excede segundo o autor o requerimento da seringueira e portanto onde houver nódulos desenvolvidos e fixando, a aplicação de nitrogenados deve ser reduzida ou dispensada entre o terceiro e o quinto ano.

Conforme o artigo "Cycle of nutrients in rubber plantation"(1972), a presença ou não de plantas cultivadas entre as linhas de plantio, durante os primeiros anos de cultivo da seringueira, contribui muito para impedir processos erosivos, auxiliando na ciclagem de nutrientes, assim como muitas vezes, poderiam servir como uma cultura economicamente viável, que cobriria os investimentos durante a fase improdutiva. Quando a cultura intercalar for uma leguminosa, o maior retorno nutricional na ciclagem, principalmente em relação ao nitrogênio, resultará na aceleração do crescimento da árvore, antecipando a maturidade. 
Com a utilização de cobertura vegetal do solo, há um aumento do teor de matéria orgânica do solo, que consiste em resíduos de plantas e de animais em diferentes fases de decomposição. A adição de matéria orgânica beneficia o solo de várias formas :

a) melhora as condições físicas;

b) aumenta a retenção de água;

c) melhora o solo para o preparo;

d) diminue as perdas por erosão e fornece nutrientes para as plantas.

A maioria dos benefícios ocorre em função dos produtos liberados à medida que os resíduos orgânicos são decompostos no solo. A matéria orgânica contém quantidades significativas de elementos minerais, como o nitrogênio, fósforo, potássio, magnésio, cálcio, enxofre e micronutrientes. Essa matéria orgânica, à medida que se decompõe, libera os nutrientes, tornando-os disponíveis às plantas segundo Lopes (1989).

\subsection{Disponibilidade e fixação de nitrogênio pelas leguminosas}

O suprimento adequado de nitrogênio é indispensável para o pleno desenvolvimento da seringueira . A adubação nitrogenada via de regra é feita com o uso das fontes tradicionais de nitrogênio como uréia, sulfato de amônio ou nitrocálcio e tem um custo relativamente alto segundo Medrado \& Costa (1990).

Entretanto, o fornecimento de nitrogênio para as plantas é possível através da adoção de alternativas oferecidas pela própria natureza. Dentre os vários 
sistemas biológicos capazes de fixar nitrogênio atmosférico a simbiose entre leguminosas e Rhizobium parece ser a que mais contribui com nitrogênio para o ecossistema ( Franco, 1978).

O processo de fixação biológica de nitrogênio atmosférico promove a redução de $\mathrm{N}_{2}$ para $\mathrm{NH}_{3}$, usando materiais energéticos fornecidos pela fotossíntese da planta direta ou indiretamente (Döbereiner, 1978).

A grande maioria das leguminosas vivem em simbiose com bactérias fixadoras de nitrogênio livre do ar, sendo mais comum as do gênero Rhizobium que se alimentam das substâncias açucaradas produzidas pelas leguminosas durante o processo de fotossíntese.

As leguminosas porém, só podem fixar quando desenvolvem associação altamente especializada com a bactéria específica. Sem o Rhizobium a leguminosa pode crescer mas não usar o nitrogênio atmosférico. Por outro lado o Rhizobium pode também permanecer livremente no solo mas não fixar nitrogênio. Os dois organismos podem viver, crescer, independentemente mas só podem fixar o nitrogênio quando em simbiose (Loneragan, 1960).

Durante a fase imatura da seringueira, em que as leguminosas crescem bem mais rápido, o nitrogênio atmosférico é fixado por bactérias simbióticas nos nódulos das plantas de cobertura proporcionando desta forma mais rápido desenvolvimento da seringueira ( Pushparajah \& Chellapah,1969).

Segundo Franco \& Souto (1984), as leguminosas comumente usadas em adubação verde fixam, em média, $180 \mathrm{~kg}$ de N/ha/ano que é adicionado ao solo, podendo assim contribuir na economia de nitrogênio. Com essa prática pode-se recuperar, em parte ou no todo, a fertilidade do solo perdida devido ao manejo inadequado ou adoção de monocultivo, fornecendo nitrogênio à cultura seguinte 
evitando, assim adubos altamente solúveis que podem poluir o ambiente ( Kohl et al.,1971).

Entretanto , para obter um excelente resultado com a adubação verde é necessário que haja compatibilidade do cultivo da leguminosa com a cultura beneficiada, assim como, otimizar os demais fatores de produção. Os benefícios resultantes da adubação verde podem ser incrementados pela inoculação com bactérias dos gêneros Rhizobium e Bradyrhizobium mais eficientes, associação com fungos micorrízicos, aplicações mais elevadas de fosfatos naturais e a inclusão de micronutrientes como, molibdênio e cobalto, o que justifica a intensificação dos trabalhos de pesquisa e experimentação em todo país (Franco \& Souto, 1984).

A prática de uso de adubos verdes ainda continua restrita a um número reduzido de agricultores. A grande limitação do uso de leguminosas para adubação verde está na compatibilização do cultivo da cultura na mesma área segundo Franco \& Souto (1984), na perda de área de cultivo da cultura comercial (Miyasaka, 1984) e a dificuldade de determinar com precisão a real contribuição do adubo verde na nutrição das plantas cultivadas (Muraoka, 1984).

Segundo Bulisani et al., (1987), há vários sistemas de cultivo, incluindo a utilização de leguminosas como cobertura de solo, no outono-inverno, que têm apresentado resultados satisfatórios, tanto na obtenção de renda extra no período da entressafra de culturas de verão quanto em termos de produção e melhoria do solo, com efeitos benéficos na cultura subsequente.

$\mathrm{O}$ potencial das leguminosas como adubo verde em fornecer nitrogênio às plantas, além dos fatores do meio, depende de sua capacidade de fixar nitrogênio. Franco \& Souto, (1984), determinaram o potencial de fixação de nitrogênio da mucuna-preta ( $\left.157 \mathrm{~kg} \mathrm{~N} \mathrm{ha}^{-1} / \mathrm{ano}^{-1}\right)$ e do guandu (41 a $280 \mathrm{~kg} \mathrm{~N} \mathrm{~kg}^{-1}$ ano $\left.{ }^{-1}\right)$. 
Ladd \& Jackon (1983), verificaram em ensaios de campo que o aproveitamento por culturas, do nitrogênio do adubo verde, foi maior em solo mais rico em nitrogênio obtendo $28 \%$ contra $20 \%$ de recuperação (aproveitamento) no solo mais pobre em N. Os autores observaram uma rápida estabilização do $\mathrm{N}$ de leguminosas com baixa relação $\mathrm{C} / \mathrm{N}$ e este fenômeno durou aproximadamente 6 meses. Tal fato pode influir no efeito residual do segundo plantio realizado após a incorporação do resíduo de leguminosas. Ladd \& Jackon, (1983) encontraram, também, valores menores que 5\% de recuperação do $\mathrm{N}$ de leguminosas no segundo cultivo.

Stanford \& Epstein (1974) afirmam que existe uma grande correlação entre temperatura e umidade do solo para a realização da mineralização do $\mathrm{N}$ no solo, e mostram que houve um pico máximo em todos os tratamentos para $\mathrm{NNO}^{-3}$ aos 60 e 75 dias de incubação. Freitas, (1984), observou que os maiores valores encontrados para a umidade do solo estavam entre 30 e 45 dias, diminuindo logo em seguida, e o fator umidade favoreceu uma maior nitrificação do $\mathrm{N}$ aos 60 dias.

Myers et al.,(1982), trabalhando com cinco solos diferentes e duas profundidades, observaram que à medida que se aumentavam a umidade do solo, a taxa de mineralização do $\mathrm{N}$ aumentava. Em média , esta correlação era observada até $35-55 \%$ de umidade no solo.

\subsection{Influência da temperatura}

Um dos fatores ambientais, que afeta praticamente todos os processos fisiológicos das plantas é a temperatura. Afeta a germinação, a respiração, a 
transpiração, a atividade fotossintética e membranas celulares, a absorção de água e de nutrientes, a velocidade das reações químicas nas plantas e, portanto, influi sobre todos os processos metabólicos. Existe uma faixa de temperatura favorável ao crescimento das plantas, a qual pode ser diferente para cada órgão ou fase de desenvolvimento da planta. Os estudos nesse sentido mostram que existem a temperatura mínima ( limite inferior para realização do crescimento); a temperatura máxima ( limite superior para a realização do processo) e a temperatura ótima (nível apropriado para o crescimento de máxima intensidade). O aumento da temperatura até um determinado ponto acelera os processos, mas a partir dele em função da fase de crescimento e da espécie, o metabolismo das plantas passa a ser prejudicado, ocorrendo em situações extremas desnaturação de proteínas, inativação do material enzimático e desidratação de células. Influi, dessa forma, na sequência normal do crescimento e pode, inclusive, tornar-se letal à planta.

Nos solos cobertos as variações térmicas são pequenas, o teor de umidade é maior, enquanto no solo nu a temperatura tem maior amplitude de variação, podendo atingir valores muito altos, inadequados para as raízes. A cobertura do solo, evitando o aquecimento excessivo das primeiras camadas do solo é um fator muito importante para a preservação da matéria orgânica presente no solo, podendo determinar ao longo dos anos, acréscimos no teor de matéria orgânica do solo, através da dupla ação da cobertura, protegendo os solo e incorporando progressivamente o material vegetal segundo Medrado \& Costa ( 1990).

Estudos realizados por Derpsch et al., (1983), demonstram que a cobertura vegetal com leguminosas promoveu a redução da temperatura do solo, ativando a vida biológica, o que, como consequências, favorece a transformação da palha em matéria orgânica, além de contribuir para maior aeração do terreno. Este estudo 
demonstrou também o aumento do teor de umidade, o que na época de estiagem pode representar acréscimo de até $100 \%$ na produção final.

Medcalf (1956) observou que aplicações de cobertura vegetal morta em cafeeiros causa uma diminuição acentuada na temperatura do solo. De acordo com Bavel (1972) e Haynes (1980), temperaturas baixas do solo podem ser benéficas para o desenvolvimento das plantas durante o verão ou prejudiciais para as culturas perenes durante $o$ inverno.

Do ponto de vista agronômico, a importância da temperatura do solo está na influência que exerce principalmente no crescimento radicular segundo Nye \& Tinker (1977), absorção de íons e água (Epstein, 1972), e nas atividades microbiológicas do solo ( Voss \& Sidiras, 1985).

Sidiras \& Pavan (1986), mostram que as menores temperaturas do solo a $3 \mathrm{~cm}$ de profundidade, proporcionadas pelo plantio direto foram atribuídas à influência de resíduos vegetais na superfície, atuando como isolante térmico e, consequentemente, reduzindo a quantidade de calor armazenada no solo. Ainda relatam que ocorrem menores variações horárias na temperatura do solo no referido sistema de cultivo.

Entre as principais vantagens da cobertura da superfície, tem-se a redução das perdas de água por evaporação ( Lal, 1974), e diminuição das temperaturas máximas do solo em períodos quentes e secos, chegando a reduções de $13^{\circ} \mathrm{C}$ a 5 $\mathrm{cm}$ de profundidade do solo, em comparação com o solo descoberto (Derpsch et al., 1983).

Derpsch et al., (1985), determinaram num experimento na região de Londrina (PR), em solo descoberto, período de temperaturas superiores a $40^{\circ} \mathrm{C}$ em novembro e dezembro e de até $50^{\circ} \mathrm{C}$ em janeiro a $3 \mathrm{~cm}$ de profundidade. Da mesma forma, Lal (1974), na Nigéria, observou temperaturas de $38^{\circ} \mathrm{C}$ a $42^{\circ} \mathrm{C}$ a 5 
cm de profundidade e Costa \& Godoy (1962) em solo de terra-roxa observaram temperaturas superiores a $48^{\circ} \mathrm{C}$ na superfície do solo. A seguir apresentamos dados obtidos na Estação Experimental do IAPAR (Oliveira) ${ }^{3}$ em dezembro de 1990 (Tabela 2).

Tabela 2. Temperatura do solo registrada as 15 horas de 25/12/90

\begin{tabular}{llll}
\hline Profundidade & Solo nu & Solo c/palha & Solo c/grama verde
\end{tabular}

$\begin{array}{llll}2 & 60 & 29.3 & 33.0 \\ 5 & 42 & 27.7 & 31.0 \\ 10 & 38 & 27.4 & 29.4 \\ 20 & 33 & 26.4 & 28.6\end{array}$

Fonte. IAPAR - Estação Experimental de Palotina- PR

A manutenção da resteva na superfície do solo vem sendo amplamente utilizada como alternativa para diminuir as variações de temperatura do solo, reduzindo-lhe as perdas por erosão, retendo maior quantidade de água no solo e promovendo maiores rendimentos dos cultivos agrícolas de acordo com Bragagnolo \& Mielniczuk, (1990), Unger \& McCalla, (1980).

Segundo Döbereiner \& Aronovich (1966) temperaturas do solo acima de $30^{\circ} \mathrm{C}$ prejudicam a nodulação, a fixação de nitrogênio e também Sichmann (1977) afirma que temperatura acima de $33^{\circ} \mathrm{C}$, prejudica a formação de nódulos em raízes de soja . Também Dart \& Mercer, (1965); Dart et al. 1976, afirmam que temperaturas de $42^{\circ} \mathrm{C}$ e $45^{\circ} \mathrm{C}$ estão bem acima daquelas toleradas pelos nódulos da maioria das leguminosas tropicais.

\footnotetext{
3 OLIVEIRA, E. de; ( INTITUTO AGRONÔMICO do PARANÁ, Palotina ), Comunicação pessoal. 1995.
} 
Todavia Primavesi, (1992), relata que num solo descoberto a temperatura pode chegar a $76^{\circ} \mathrm{C}$ no verão, sendo que as plantas não absorvem água a partir de $32^{\circ} \mathrm{C}$, e somente o algodoeiro pode absorver água até $39^{\circ} \mathrm{C}$. Franco, (1958) submeteu o sistema radicular do cafeeiro a diferentes temperaturas e obteve a transpiração máxima quando a temperatura atingiu $33^{\circ} \mathrm{C}$, abaixo de $28^{\circ} \mathrm{C}$ e acima de $33^{\circ} \mathrm{C}$ houve um decréscimo e ainda Franco, (1961) observa o aparecimento de lesões no colo de mudas de cafeeiros quando estas foram submetidas à temperaturas de 44 a $51^{\circ} \mathrm{C}$. Os mesmos efeitos foram verificados por Carnauba \& Ortolani (1966), no ponto de enxertia de mudas de abacateiro. 


\section{MATERIAL E MÉTOdOS}

O experimento foi conduzido na Escola Superior de Agricultura "Luiz de Queiroz", localizada no Município de Piracicaba, Estado de São Paulo, cujas as coordenadas são $22^{\circ} 42^{\prime}$ de latitude Sul e $47^{\circ} 38^{\prime}$ de longitude Oeste; com altitude de 546m ; o clima é do tipo tropical continental, com temperatura média do ar: $21,1^{\circ} \mathrm{C}$, temperatura média máxima: $27,8^{\circ} \mathrm{C}$, temperatura média mínima: $14,3^{\circ} \mathrm{C}$; precipitação média: $1257 \mathrm{~mm}$. ano $^{-1}$; umidade relativa média: $74 \%$; insolação média: $6,6 \mathrm{~h} \cdot \mathrm{dia}^{-1}$; radiação solar: $436 \mathrm{cal} \cdot \mathrm{cm}^{-2} \cdot \mathrm{d}^{-1}$.

O ensaio de campo teve a duração de 12 meses, sendo seu início em fevereiro de 1995 e término em fevereiro de 1996. Os dados climáticos (médias mensais) da região de Piracicaba, estão na tabela 3.

\subsection{Cultivar de seringueira}

O cultivar estudado foi o GT 1. È um cultivar primário, originário de Java. de acordo com IRCA ( 1985), apresenta folhas em tons verde escuro e brilhante, tronco ereto com poucas saliências, ramificação equilibrada, o que diminui a suscetibilidade à quebras por ventos. 
Tabela 3. Dados climáticos (médias mensais) da região de Piracicaba, SP.

\begin{tabular}{lccccccc}
\hline Mês & $\begin{array}{l}\text { Insol. } \\
(\mathrm{h} / \mathrm{d})\end{array}$ & $\begin{array}{l}\text { Precip. } \\
(\mathrm{mm})\end{array}$ & $\begin{array}{l}\text { UR } \\
(\%)\end{array}$ & $\begin{array}{l}\text { Vento } \\
\text { médio } \\
(\mathrm{Km} / \mathrm{h})\end{array}$ & $\begin{array}{l}\text { Temp. } \\
\text { máx. }\left({ }^{\circ} \mathrm{C}\right)\end{array}$ & $\begin{array}{l}\text { Temp. } \\
\text { mín. }\left({ }^{\circ} \mathrm{C}\right)\end{array}$ & $\begin{array}{l}\text { Temp. } \\
\text { méd. }\left({ }^{\circ} \mathrm{C}\right)\end{array}$ \\
\hline fev/95 & 4.58 & 415.6 & 88.2 & 6.89 & 29.94 & 20.01 & 24.97 \\
mar/95 & 5.43 & 194.6 & 83.5 & 7.38 & 30.44 & 18.84 & 24.46 \\
abr/95 & 7.82 & 85.7 & 81.4 & 6.59 & 29.21 & 15.96 & 22.59 \\
mai/95 & 6.3 & 64.2 & 84.6 & 5.89 & 25.94 & 13.7 & 19.82 \\
jun/95 & 7.09 & 23.5 & 79.8 & 7.56 & 25.96 & 11.37 & 18.66 \\
jul/95 & 6.59 & 59.1 & 77.39 & 7.22 & 26.78 & 12.87 & 19.83 \\
ago/95 & 9.00 & 1.2 & 68.06 & 8.32 & 30.35 & 13.05 & 21.7 \\
set/95 & 6.66 & 37.6 & 71.63 & 10.45 & 28.85 & 14.05 & 21.45 \\
out/95 & 6.43 & 190.2 & 76.16 & 9.65 & 28.34 & 15.79 & 22.06 \\
nov/95 & 8.13 & 156.3 & 72.07 & 9.55 & 30.08 & 17.28 & 23.68 \\
dez/95 & 6.72 & 222.2 & 77.65 & 9.15 & 30.09 & 18.81 & 24.45 \\
jan/96 & 6.6 & 314.8 & 80.71 & 6.79 & 31.19 & 20.3 & 25.74 \\
fev/96 & 6.23 & 258.3 & 84.34 & 7.71 & 31.84 & 20.11 & 25.98 \\
\hline
\end{tabular}

Fonte: Posto Meteorológico da Escola Superior de Agricultura "Luiz de Queiroz"Piracicaba, SP.

É um cultivar de importância a nível mundial. No Estado de São Paulo passou a ser recomendado para plantio a partir da década de 80 , como estratégia para diversificação dos clones, sendo recomendado a partir de então juntamente com os clones PB 235, RRIM 600 e IAN 873 (Medrado \& Costa, 1990). 


\subsection{Espécies de leguminosas}

Foram utilizadas as leguminosas: mucuna-preta (Mucuna aterrima Merr.) e guandu ( Cajanus cajan (L) Millsp), cujas características são apresentadas a seguir.

A mucuna-preta é planta de crescimento rasteiro e vigoroso, de ciclo anual ou semi-perene e de ampla adaptação, recomendada, sobretudo, para adubação verde. Apresenta comprovada eficiência no controle da população de nematóides formadores de galhas, e sua produção de matéria seca pode alcançara 10 t.ha $^{-1}$. $\mathrm{O}$ ciclo, do plantio a colheita das vagens pode chegar a 240 dias, mas para fins de adubação verde, recomenda-se o corte na época de florescimento, por volta de 120 dias ( Bulisani \& Braga, 1987).

As características agronômicas de alta produtividade e grande capacidade de fixação biológica do nitrogênio (FBN), comprovado controle de nematóides, e a grande aceitação e utilização em grande escala para fins de adubação verde, segundo Mascarenhas et al (1994).

O guandu é uma planta semi-perene, arbustiva, está adaptada a latitudes variando de $30^{\circ} \mathrm{N}$ a $30^{\circ} \mathrm{S}$. È considerada o "zebu" das leguminosas, dada a sua rusticidade. Mantém-se verde durante todo o ano. Seu desenvolvimento inicial é lento e seu ciclo até a colheita é de 240 a 270 dias. Desenvolve-se melhor na faixa de temperatura de $18^{\circ}$ a $30^{\circ} \mathrm{C}$, não estando adaptada a condições de frio, geadas e encharcamento de solo.

Planta de múltiplos usos, pode ser utilizada na adubação verde; na alimentação, tanto humana quanto animal. Seu sistema radicular é vigoroso e bem desenvolvido em profundidade, conferindo-lhe resistência a períodos prolongados 
de estiagem e efeitos físico-químicos do solo e apresenta também uma elevada produção de biomassa segundo Calegari (1995), e Wutke ( 1987).

É uma espécie considerada mobilizadora de nutrientes e recuperadora de solos depauperados, devendo, nesse caso, ocupá-los por três ou quatro anos.

Utilizado com vantagem na rotação com milho ( aumentos de $21 \%$ ), arroz, soja, feijão( aumentos de 52\%), cana-de-açúcar, trigo, algodão, culturas perenes (frutíferas, café), em faixas (pastos, mandioca), etc., segundo Wutke (1993).

Essas características colaboraram para a escolha e utilização das duas espécies de leguminosas presente neste trabalho.

\subsection{Solo e análise química e física}

O seringal está situado em área de Latossolo Roxo; é um seringal jovem com árvores de quatro anos de idade. Foi realizada uma coleta de solo, janeiro de 1995, com uso de trado holandês. Foram coletados 10 amostras simples, as quais foram homogeneizadas, formando a amostra composta. As coletas foram realizadas nas profundidades de $0-20 \mathrm{~cm}$ e $20-40 \mathrm{~cm}$. As amostras compostas foram enviadas ao Departamento de Ciência do Solo da ESALQ/USP, para análise química e física do solo. Os valores são dados na tabela 4 e 5 .

Quanto a seringueira foram coletadas folhas do último lançamento maduro de vinte árvores ao acaso, coletando folhas no sentido leste, oeste, norte e sul, e estas formaram duas amostras compostas, a seguir foram enviadas ao Departamento de Ciência do Solo da ESALQ \USP, para análise química. Essa coleta foi realizada na mesma data da coleta de solo. Os valores encontrados estão na tabela 6. 
Tabela 4. Resultados da análise química do solo da área do experimento.

\begin{tabular}{lcc}
\hline & Profundidade & Profundidade \\
& $0-20 \mathrm{~cm}$ & $20-40 \mathrm{~cm}$ \\
\hline P. resina & 58 & 44 \\
Matéria orgânica (\%) & 2.5 & 2.1 \\
$\mathrm{pH} \mathrm{CaCl} 2$ & 5.3 & 5.4 \\
$\mathrm{~K}\left(\mathrm{meq} / 100 \mathrm{~cm}^{3}\right)$ & 0.51 & 0.37 \\
$\mathrm{Ca}\left(\mathrm{meq} / 100 \mathrm{~cm}^{3}\right)$ & 5.15 & 4.5 \\
$\mathrm{Mg}\left(\mathrm{meq} / 100 \mathrm{~cm}^{3}\right)$ & 1.95 & 1.33 \\
$\mathrm{H}+\mathrm{Al}\left(\mathrm{meq} / 100 \mathrm{~cm}^{3}\right)$ & 3.05 & 3.73 \\
$\mathrm{~S}\left(\mathrm{meq} / 100 \mathrm{~cm}^{3}\right)$ & 7.6 & 6.2 \\
$\mathrm{CTC}\left(\mathrm{meq} / 100 \mathrm{~cm}^{3}\right)$ & 10.65 & 9.96 \\
$\mathrm{Saturação} \mathrm{em} \mathrm{bases}(\%)$ & 71.25 & 62.6 \\
\hline
\end{tabular}

\subsection{Instalação e condução do experimento}

O seringal onde foi realizado o experimento foi plantado em 1991, totalizando 144 árvores úteis. O espaçamento de plantio foi de $8,00 \times 2,50 \mathrm{~m}$, ou 
seja, $20 \mathrm{~m}^{2}$ por planta. A área total do experimento foi de 0,28 ha. Cada parcela têm uma área útil de $180 \mathrm{~m}^{2}$, com um total de 16 parcelas, dentro de cada parcela têm 9 árvores úteis.

Tabela 5 . Características físicas do solo da área experimental

\begin{tabular}{lccccc}
\hline Profundidade & \multicolumn{4}{c}{ Textura (\%) } & Classificação \\
\cline { 2 - 5 } & A G. & A F. & Silte & Argila & Textural $\left({ }^{*}\right)$ \\
\hline $0-20 \mathrm{~cm}$ & 7 & 25 & 16 & 53 & argilosa \\
$20-40 \mathrm{~cm}$ & 6 & 23 & 14 & 58 & argilosa \\
\hline
\end{tabular}

Método do densímetro .

(*)Segundo a Sociedade Brasileira de Ciência do Solo.

A bordadura é constituída por 16 plantas. Os tratos culturais constaram basicamente do controle do mato nas linhas da seringueira e nas parcelas testemunhas, feito com herbicidas e capinas manuais e controle de formigas.

$\mathrm{O}$ preparo do solo, nas entrelinhas da seringueira constou de uma aração $\mathrm{e}$ duas gradagens. Foi respeitado uma faixa lateral de $2,50 \mathrm{~m}$ da seringueira $\mathrm{e}$ estabelecidas 7 linhas para a semeadura das leguminosas. A semeadura foi feita no espaçamento de $0,50 \mathrm{~cm}$ entrelinhas e $0,20 \mathrm{~cm}$ entre plantas.

Foi realizado um teste de germinação nas sementes, onde as duas espécies apresentaram um excelente índice de germinação, o que também dispensou qualquer tipo de escarificação da semente de mucuna-preta. Foi plantada média 8 
sementes de leguminosas por metro linear para mucuna-preta e 20 sementes para o guandu.

Tabela 6. Resultados das análises de plantas inicial

\begin{tabular}{ccccccc}
\hline Amostras & $\mathrm{N}$ & $\mathrm{P}$ & $\mathrm{K}$ & $\mathrm{Ca}$ & $\mathrm{Mg}$ & $\mathrm{S}$ \\
& & & $(\%)$ & & & \\
\hline 1 & 3.75 & 0.26 & 1.50 & 1.51 & 0.30 & 0.29 \\
2 & 3.70 & 0.25 & 1.48 & 1.60 & 0.30 & 0.29 \\
\hline
\end{tabular}

Detalhe da parcela

\begin{tabular}{|ccccc|}
\hline 0 & 0 & 0 & 0 & 0 \\
0 & $\mathbf{x}$ & $\mathbf{x}$ & $\mathbf{x}$ & 0 \\
0 & $\mathbf{x}$ & $\mathbf{x}$ & $\mathbf{x}$ & 0 \\
0 & $\mathbf{x}$ & $\mathbf{x}$ & $\mathbf{x}$ & 0 \\
0 & 0 & 0 & 0 & 0 \\
\hline
\end{tabular}

$$
0=\text { bordadura } \quad \mathrm{x}=\text { planta útil }
$$




\subsection{Análise estatística}

Foi adotado um delineamento experimental em parcelas subdivididas, 0 objetivo desse tipo de experimento é estudar o efeito global dos níveis dos tratamentos ao longo do período definido, e a variação desses níveis ao longo do tempo. As parcelas estão dispostas inteiramente casualizadas.

A análise estatística foi realizada com o uso da Análise da Variância e do Teste F. Para a comparação das médias dos tratamentos foi utilizado o Teste de Tukey para todas as variáveis. o programa estatístico utilizado para as análises foi o SAS (Statistical Análysis System, (1989).

\subsubsection{Modelo estatístico}

Adotou-se neste trabalho a análise estatística tomando-se como base o delineamento de parcelas subdivididas, Obteve-se então o seguinte modelo matemático:

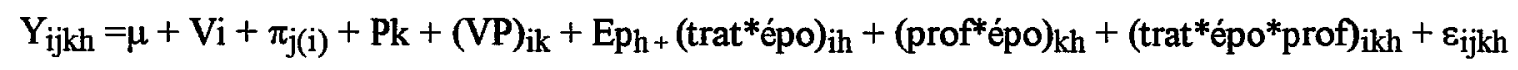

onde:

$$
\begin{aligned}
\mu & =\text { constante (média) } \\
V_{i} & =o \text { efeito da i-ésima tratamento }
\end{aligned}
$$


$\pi \mathrm{j}(\mathrm{i})=\mathrm{o}$ efeito da repetição $\mathrm{j}$ dentro do i-ésimo tratamento, sendo utilizado como resíduo (A),

$P_{k}=o$ efeito da profundidade

$E p_{h}=o$ efeito da época

$(V p)_{i k}=o$ efeito da interação trat $x$ prof

(trat $\mathrm{x}$ épo)ih $=0$ efeito da interação trat $\mathrm{x}$ época

(Prof $x$ época) $k h=0$ efeito da interação prof $x$ época

(trat $\mathrm{x}$ épo $\mathrm{x}$ prof $)_{\mathrm{ikh}}=\mathrm{o}$ efeito da interação trat $\mathrm{x}$ época $\mathrm{x}$ prof

$\varepsilon_{\mathrm{ijkh}}=$ é o erro experimental da sub-sub parcela

Hipóteses a serem testadas :

1) Ho : V1=V2=V3=V4, não existe diferença nos efeitos dos tratamentos $\mathrm{Ha}: \mathrm{Vi} \neq 0$, para algum $\mathrm{i}$

2) Ho : P1=P2, para todo $k$

3) Ho : Ep1= ep2=ep3=ep4=ep5=ep6=ep7=ep8 
Tabela 7. Estrutura da análise da variância .

\begin{tabular}{llll}
\hline C.V. & GL & QM & F \\
\hline tratamento & $(\mathrm{a}-1)$ & QM t & QMv/QM(a) \\
resíduo (A) & $(\mathrm{r}-1) \mathrm{a}$ & $\mathrm{QMr}(\mathrm{a})$ & \\
\hline Parcelas & & & \\
\hline Profundidade & $(\mathrm{b}-1)$ & QM prof & QMpro/QMr(b) \\
Trat x Prof & $(\mathrm{a}-1)(\mathrm{b}-1)$ & QMtratxpro & QMtratxpro/QMr(b) \\
resíduo (B) & $(\mathrm{r}-1) \mathrm{a}(\mathrm{b}-1)$ & $\mathrm{QM}$ r(b) & \\
\hline sub-parcela & & & \\
\hline Época & $(\mathrm{c}-1)$ & QMépoca & QMép/QM r(c) \\
Trat x época & $(\mathrm{a}-1)(\mathrm{c}-1)$ & QM tratxép & QMtratxep/QMr(c) \\
Prof x época & $(\mathrm{b}-1)(\mathrm{c}-1)$ & QMprofxép & QMproxep/QMr(c) \\
trat x prof x épo & $(\mathrm{a}-1)(\mathrm{b}-1)(\mathrm{c}-1)$ & QMtratxproxep & QMtrxprxep/QMr(c) \\
resíduo ( C) & $(\mathrm{r}-1)(\mathrm{c}-1) \mathrm{a}+(\mathrm{r}-1)(\mathrm{b}-1)(\mathrm{c}-) \mathrm{a}$ & $\mathrm{QMr}(\mathrm{c})$ & \\
\hline sub-sub-parcela & & & \\
\hline Total & & &
\end{tabular}

Total 


\section{6. Tratamentos}

O trabalho é constituído pelos seguintes tratamentos: quatro parcelas de mucuna-preta (CMM) e quatro parcelas do guandu (CMG) foram cortadas no florescimento avaliadas como cobertura morta. Outras quatro parcelas de guandu (Guandu) permaneceram vegetando, e quatro parcelas de solo nu totalmente limpo através de uso de herbicidas ou capinas ( testemunha) (tabela 8). Um aspecto geral do experimento apresentado na figura 1. Nas parcelas de cobertura morta as leguminosas foram cortadas em 01 de julho de 1995 e partir daí começaram as coletas de solo para determinação do N-mineral e umidade e também as leituras de temperatura do solo nas diferentes coberturas (tabela 9).

Tabela 8. Notação dos tratamentos

Número

1

2

3

4
Tratamento

CMG (Cobertura morta de guandu)

CMM (Cobertura morta de mucuna-preta)

Guandu (Guandu permanente)

Testemunha (Solo nu) 
Tabela 9. Notação das épocas de coletas

\begin{tabular}{cc}
\hline Números & Épocas de coletas \\
\hline 1 & julho de 1995 \\
2 & agosto de 1995 \\
3 & setembro de 1995 \\
4 & outubro de 1995 \\
5 & novembro de 1995 \\
6 & dezembro de 1995 \\
7 & janeiro de 1996 \\
8 & fevereiro de 1996 \\
\hline
\end{tabular}

\subsection{Variáveis analisadas:}

Foram avaliados em cada tratamento, as seguintes variáveis

\subsubsection{Temperatura do solo}

Foram instalados geotermomêtros nos diferentes tratamentos a 2, 5, 10, 20 e $30 \mathrm{~cm}$ de profundidade do solo. 

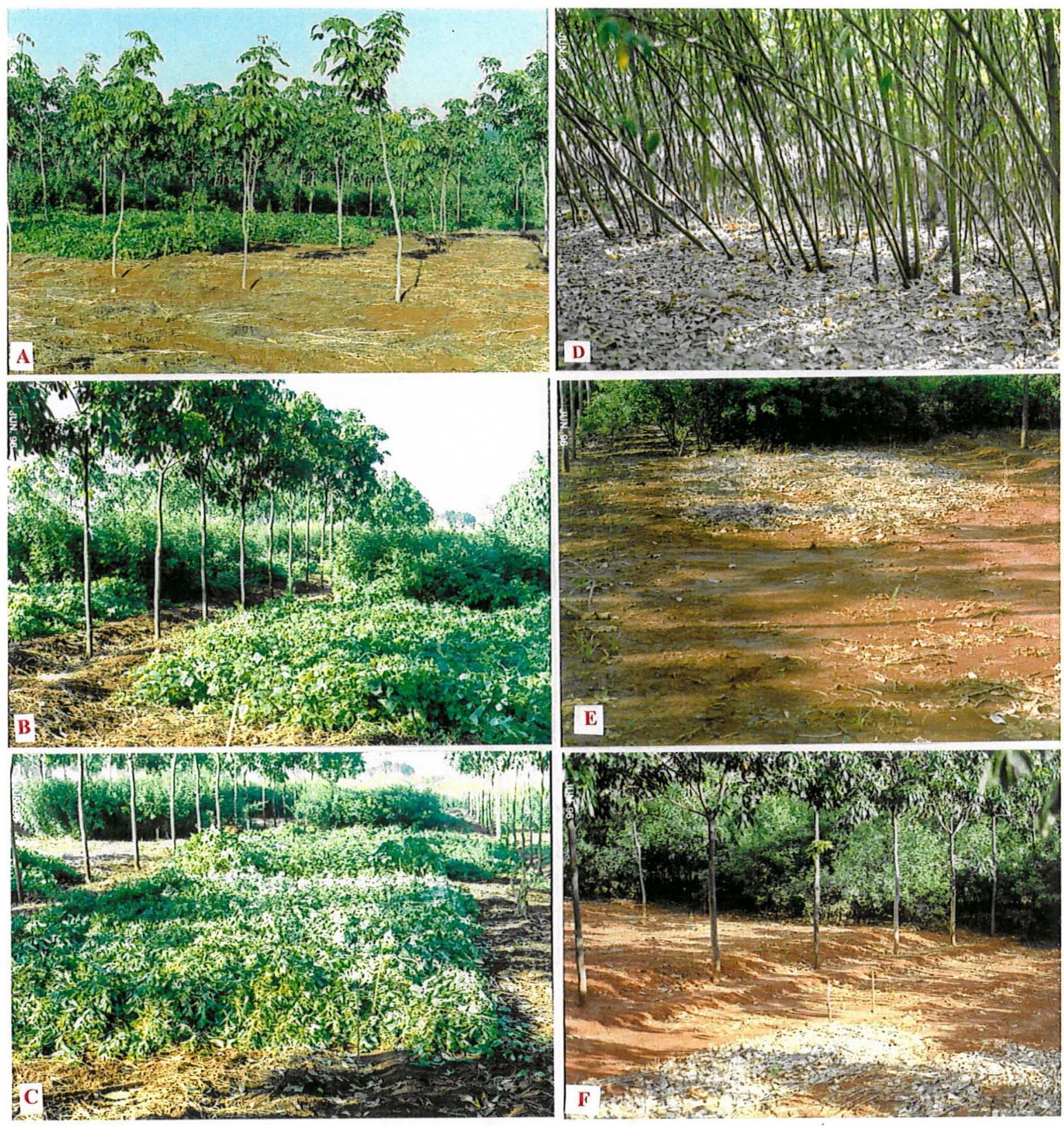

Figura 1 . Aspectos gerais do experimento: a) Aspectos das parcelas antes do corte da cobertura morta; b) parcela de mucuna-preta e outra de guandu antes do corte; c) parcelas de guandu cortado e guandu permanente; d) palhada em baixo do guandu permanente; e) aspectos do solo nu comparado com guandu permanente; f) deslocamento superficial de partículas do solo da parcela testemunha. Piracicaba - SP. ESALQ/USP. 1995/96. 
Esses geotermomêtros foram instalados em 01 julho de 95 e permaneceram ao solo até final de fevereiro de 96. As leituras aconteceram durante duas ou três vezes por semana, duas vezes ao dia, no período da manhã sempre às 7:00 horas e sempre às 14:00 horas da tarde, para acompanhar os valores no período de mínima e máxima temperatura diária. Isso tudo para as diferentes coberturas. Os dados obtidos são em ${ }^{\circ} \mathrm{C}$.

\subsubsection{Nitrogênio mineral do solo e planta}

O nitrogênio mineral no solo e na planta foram determinados pela importância que eles representam, para a vida das plantas.

\subsubsection{1 . Determinação do nitrogênio mineral}

O método utilizado para análise de nitrogênio em solos e folhas foi o semimicro com modificações do macro-Kjedahl descrito por Bremner (1965).O método envolve a extração da amostra de solo com $\mathrm{KCl} 2 \mathrm{~N}$ e posterior análise do extrato por destilação a vapor, adicionando-se, extrato de $\mathrm{MgO}$ e Liga de Devarda, para liberação de $\mathrm{NH}_{3}$ e redução de $\mathrm{NO}_{2}^{-}$e $\mathrm{NO}_{3}^{-}$a $\mathrm{NH}_{3}$, respectivamente.

3.7.2.2. Análise do $\mathrm{N}$-mineral $\left(\mathrm{NH}^{+}{ }_{4}, \mathrm{NH}_{3}^{-}\right)$do solo e planta

Foram coletadas amostras de solos mensalmente a partir de junho de 1995,

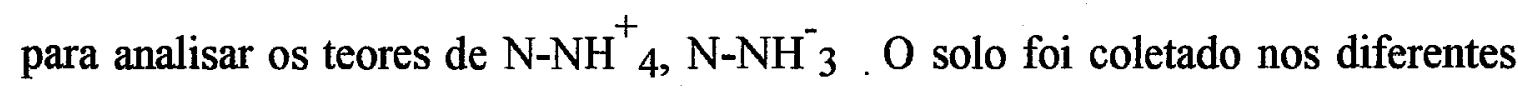


tratamentos e em todas as repetições, com auxílio de trado de sonda, a duas profundidades ( $0-10$ e $10-30 \mathrm{~cm}$ ), em nove locais diferente dentro de cada parcela, originando uma amostra composta por parcela, representando cada amostra 300 gramas de solo.

a) Teores de nitrato e amônio

A partir da amostra coletada foi pesada aliquota de $100 \mathrm{~g}$ do solo e adicionando-se $150 \mathrm{ml}$ de $\mathrm{KCl} 2 \mathrm{~N}$, agitando-se por quatro horas em agitador. Imediatamente após este período, o solo foi centrifugado a $400 \mathrm{x}$ g por 15 minutos. O sobrenadante foi recolhido, anotado seu volume e destilado em destilador Kejdahl na presença de $\mathrm{MgO}$, para liberação de amônia e posteriormente Liga de Devarda para redução do nitrato remanescente à amônia, de acordo com Bremner (1965). O destilado foi recebido em ácido bórico, sendo titulado com $\mathrm{H}_{2} \mathrm{SO}_{4}$ a $0,01 \mathrm{~N}$, após foram determinados os valores .

Quanto a determinação do N-mineral da planta, procedeu-se da seguinte maneira. Coletou-se folhas da seringueira, em julho de 1995 e em fevereiro de 1996; dentro de cada parcela escolheu-se três árvores e coletou-se quatro folhas do ultimo lançamento maduro de cada árvore, após a coleta essas doze folhas formaram uma amostra composta. Foram enviadas imediatamente ao Laboratório de Microbiologia do CENA, onde foram colocadas em estufa à $60^{\circ} \mathrm{C}$ por 48 horas após foram moídas e pesadas $0,2 \mathrm{~g}$, colocadas em tubos, adicionando-se $6 \mathrm{ml}$ de mistura digestora e levados para digestão por 6 horas a $360^{\circ} \mathrm{C}$, após o resfriamento procedeu-se a destilação em aparelho de Kjedahl (semi-micro), com $\mathrm{NaOH} 10 \mathrm{~N}$, recebido em ácido bórico e titulado com $\mathrm{H}_{2} \mathrm{SO}_{4} 0,01 \mathrm{~N}$, de acordo com Bremner (1965). 


\subsubsection{Determinação da umidade do solo}

Em cada amostragem de solo realizada mensalmente nos diferentes tratamentos foram retiradas e homogeneizadas amostras de solo das profundidades de 10 e $30 \mathrm{~cm}$, e pesando-se $10 \mathrm{~g}$ de solo úmido e levando a estufa de $105^{\circ} \mathrm{C}$ por 48 horas, após foram pesadas novamente determinando-se o peso do solo seco e posteriormente determinando-se a \% de umidade em cada tratamento. 


\section{RESULTADOS E DISCUSSÃO}

\subsection{Teor de nitrogênio mineral no solo}

Os teores de nitrogênio mineral no solo se encontra na tabela 10.

$\mathrm{Na}$ tabela 11 são apresentados teores médios (ppm) do amônio $\left(\mathrm{NH}_{4}^{+}\right)$, nitrato $\left(\mathrm{NO}_{3}^{-}\right)$, nos quatro tratamentos e analisados durante o período de amostragem em diferentes épocas e o Teste de Tukey/tratamento.

O teor de nitrogênio mineral no solo não diferiu nos tratamentos CMG (cobertura morta de guandu), CMM (cobertura morta de mucuna-preta) e na testemunha (solo nu),e diferiu do tratamento Guandu (guandu permanente) segundo o teste de Tukey ao nível de $5 \%$ de probalidade.

No guandu o teor de nitrogênio sempre se manteve abaixo dos teores do demais tratamentos, isso mostra uma provável competição entre as arvores de seringueira e a leguminosa guandu. Esses resultados foram surpreendentes, contrariando a expectativa que a leguminosa conseguisse fixar nitrogênio pelo menos para atender as suas necessidades. Os resultados mostram que houve competição por nitrogênio. 
Tabela 10. Análise da variância e Teste $\mathrm{F}$ para os dados teor de $\mathrm{N}$ mineral do solo.

\begin{tabular}{|c|c|c|c|c|}
\hline C.V. & GL & QM & $\mathbf{F}$ & $\operatorname{Pr}>F$ \\
\hline Tratamentos & 3 & 552.8611 & 13.40 & $0.0017^{*}$ \\
\hline resíduo (a) & 8 & 41.2492 & & \\
\hline Parcelas & 11 & & & \\
\hline Profundidade & 1 & 8.6402 & 0.18 & $0.8648 \mathrm{~ns}$ \\
\hline Trat $x$ Prof & 3 & 43.9418 & 0.90 & $0.4816 \mathrm{~ns}$ \\
\hline resíduo (b) & 8 & $48 \quad .7332$ & & \\
\hline sub-parcelas & 12 & & & \\
\hline Épocas & 7 & 459.4869 & 22.72 & $0.0001 *$ \\
\hline trat $x$ época & 21 & 49.0017 & 2.42 & $0.0016 *$ \\
\hline prof $x$ época & 7 & 96.2452 & 4.76 & $0.0001 * *$ \\
\hline trat x prof x ép & 21 & 39.6854 & 1.96 & $0.0131 * *$ \\
\hline resíduo (c) & 112 & 20.2242 & & \\
\hline sub-sub-parcela & 168 & & & \\
\hline Total & 191 & & & \\
\hline \multicolumn{5}{|c|}{ * : significativo à $1 \%$} \\
\hline \multicolumn{5}{|c|}{${ }^{* *}$ : significativo ao $5 \%$ e não significativo ao $1 \%$} \\
\hline ns : não signific & & & & \\
\hline
\end{tabular}


Tabela 11. Comparação de médias de nitrogênio no solo em relação aos tratamentos

Tratamentos

Médias

Teste de Tukey

CMG (cobertura morta de guandu)

17.6

a

CMM (cobertura morta de mucuna-preta )

17.2

a

Testemunha (solo nu)

17.5

$\mathbf{a}$

Guandu (Guandu permanente)

10.7

b

Médias seguidas pela mesma letra nas colunas não diferem significativamente entre si pelo método de Tukey ( $P \geq 0.05)$.

Chandapillay (1968), afirma que a concentração do crescimento das raízes nas camadas superiores do solo promove uma competição com a seringueira por nutrientes e o "Rubber Research Institute of Malaysia" (1967); Haridas (1979) e Lopes (1989), afirmam que somente a partir do terceiro ano com a cobertura vegetal a seringueira começa a evidenciar a diferença a favor da cobertura com leguminosa em comparação com o solo nu.

Nos tratamentos CMG e CMM observou-se a evolução do teor de amônio (figura 2) no período inicial até o final. No início do experimento o teor de matéria orgânica era ótimo ( tabela 4), perdas de amônia por volatilização são dificeis de se processar em solos com $\mathrm{pH}$ em torno de 5 (Broadbent \& Stojanovic, 1952; Terman, 1979); assim, uma das alternativas para se explicar a baixa concentração de $\mathrm{NH}^{+}{ }_{4}$ durante a deposição sobre o solo seria a imobilização do N. 


$$
1=\mathrm{CMG} \quad 2=\mathrm{CMM} \quad 3=\text { Testemunha } \quad 4=\mathrm{Guandu}
$$

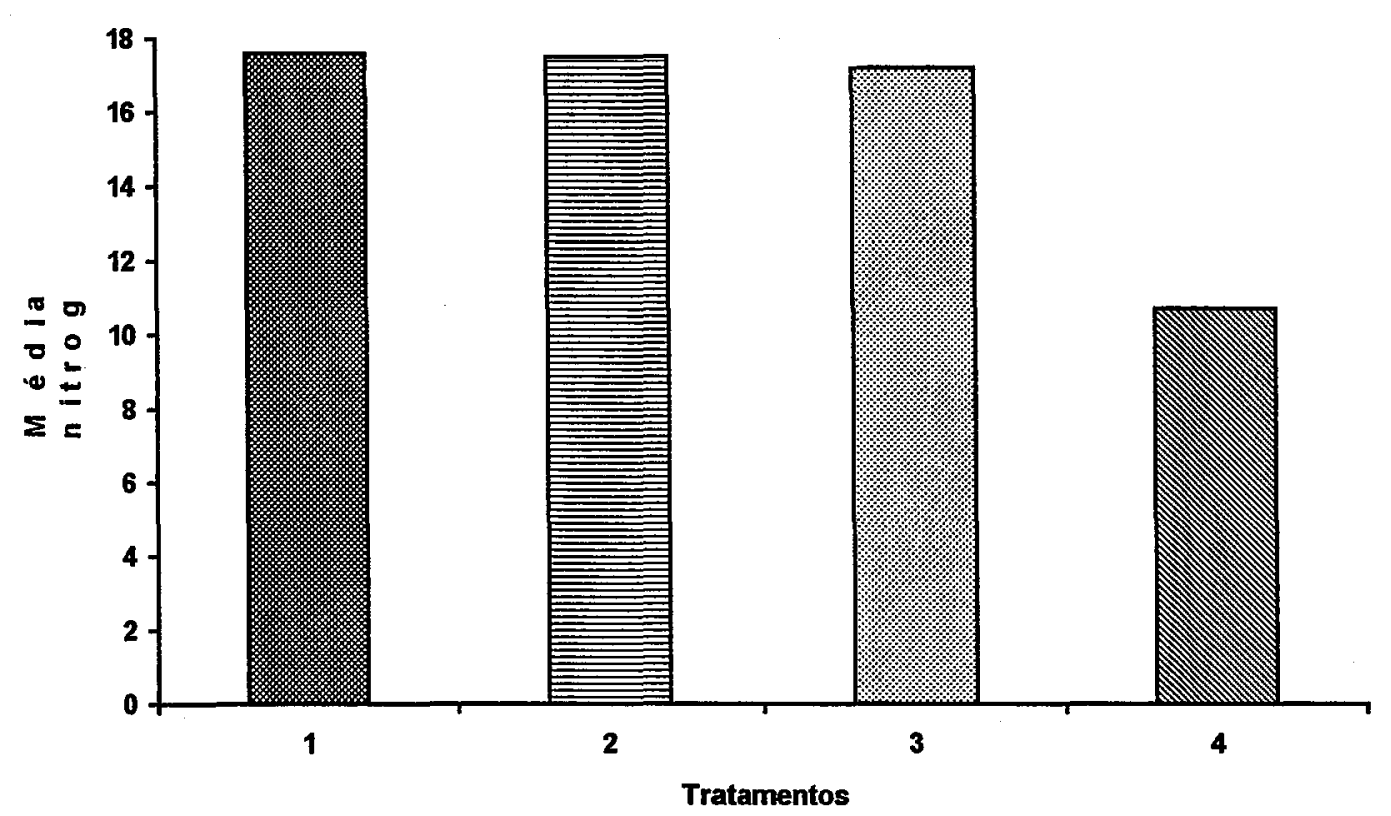

Figura 2. Evolução das médias do nitrogênio mineral do solo, nos tratamentos. Médias dos 8 períodos.

Para o CMG e o CMM o pico do teor do nitrogênio foi após 90 dias da deposição da cobertura morta (figura 4 ), assim a concentração que se manteve estável nos primeiros 60 dias se deve a imobilização do N. Após esse pico o N cai e se manteve estável novamente por mais 60 dias e aos 180 dias após a deposição da cobertura morta o $\mathrm{N}$ se elevou novamente, isso devido a altas temperaturas e chuvas intensas que ocorreram no mês de dezembro, Stanford \& Epstein (1974), Freitas (1984) e Myers et al.,(1982) confirmam essa observações que existe uma grande correlação entre temperatura e umidade do solo para a realização da mineralização do $\mathrm{N}$ no solo. Dos 180 aos 240 dias o $\mathrm{N}$ caiu e se manteve novamente, isso para todos os tratamentos (figura 4). 
Em relação a testemunha o teor de $\mathrm{N}$ foi crescente até aos 90 dias, ocorrendo uma queda por um período de mais 60 dias e subiu aos 180 dias igual ao CMG e CMM e voltou a cair até o final da observação, essa relação também está de acordo com os autores citados acima, o fator temperatura e umidade favorecem uma maior nitrificação.

A tabela 12, mostra os resultados obtidos durante os 8 meses de duração do experimento, nas diferentes profundidades do solo. Não houve diferença estatística entre as profundidades, observa-se que os teores maiores de nitrogênio mineral foi obtido no tratamento CMG na profundidade de $10 \mathrm{~cm}$ (figura 2), segundo Urquiaga (1982), a maior concentração de $\mathrm{N}$ nas camadas superficiais do solo está ligada ao fato de que há um acúmulo de matéria orgânica nestes horizontes, produtos de incorporação freqüentes de resíduos vegetais.

Tabela 12. Médias do efeito do nitrogênio do solo em relação a profundidade, por um período de 8 meses.

\begin{tabular}{ccc}
\hline Profundidade & médias & Teste Tukey \\
\hline 10 & 16.0 & $\mathrm{a}$ \\
30 & 15.5 & $\mathrm{a}$ \\
\hline
\end{tabular}

médias seguidas pela mesma letra nas colunas não diferem significativamente entre si pelo método de Tukey $(P \geq 0.05)$.

Observa-se que o CMG foi maior a $10 \mathrm{~cm}$ e caiu um pouco a $30 \mathrm{~cm}$ de profundidade. O CMM se manteve estável nas duas profundidades e todos os tratamentos foram superiores ao guandu. 
$\mathrm{O}$ guandu foi menor a $10 \mathrm{~cm}$ de profundidade e a testemunha se manteve estável nas duas profundidades. Podemos concluir que nos quatro tratamentos estudados houve uma nitrificação homogênea nesta época .

\begin{tabular}{|l|}
\hline $\mathbf{9 1 0}$ \\
\hline $\mathbf{8 3 0}$ \\
\hline
\end{tabular}

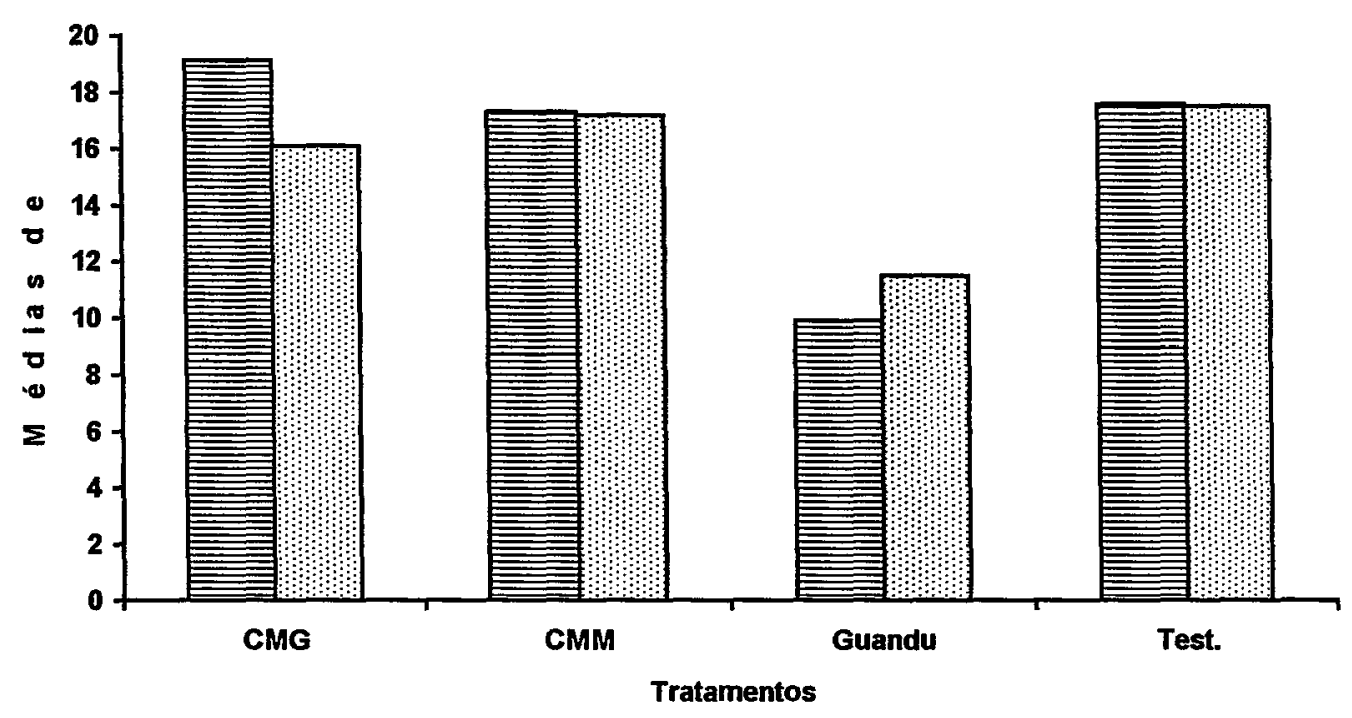

Figura 3. Disponibilidade do nitrogênio mineral do solo nos tratamentos em relação a profundidades. Médias dos 8 períodos. 
Os teores de nitrogênio no solo para as 8 épocas de amostragens estão citados na tabela 13 .

Tabela 13. Comparação das médias de nitrogênio do solo segundo épocas

\begin{tabular}{lccc}
\hline \multicolumn{1}{c}{ Época } & médias & Teste Tukey \\
\hline 1 - julho & 14.2 & a & \\
2 - agosto & 16.8 & b & c \\
3 - setembro & 23.6 & d & \\
4 - outubro & 15.4 & b & e \\
5 - novembro & 12.5 & a & e \\
6 - dezembro & 20.5 & d & c \\
7 - janeiro & 12.0 & a & e \\
8 - fevereiro & 11.1 & & a \\
\hline
\end{tabular}

médias seguidas pela mesma letra nas colunas não diferem significativamente entre si pelo método de Tukey ( $P \geq 0.05$ ).

Em relação as épocas não diferem entre si, são iguais 3 e $6 ; 2,4$ e 1; 5 , 7 e $8 ; 6$ e 3 . Sendo as melhores épocas a 3, seguida pela 6 .Está de acordo com as épocas que de maior intensidade da mineralização do nitrogênio, estas foram setembro e dezembro .

Todavia nos tratamentos o guandu sempre obteve o pior desempenho. No mês 1 e 5 o CMG foi melhor, no 2 e 3 a testemunha foi melhor, no mês $4,6,7$ e 8 foi o CMM que obteve melhor resultado (figura 4). 


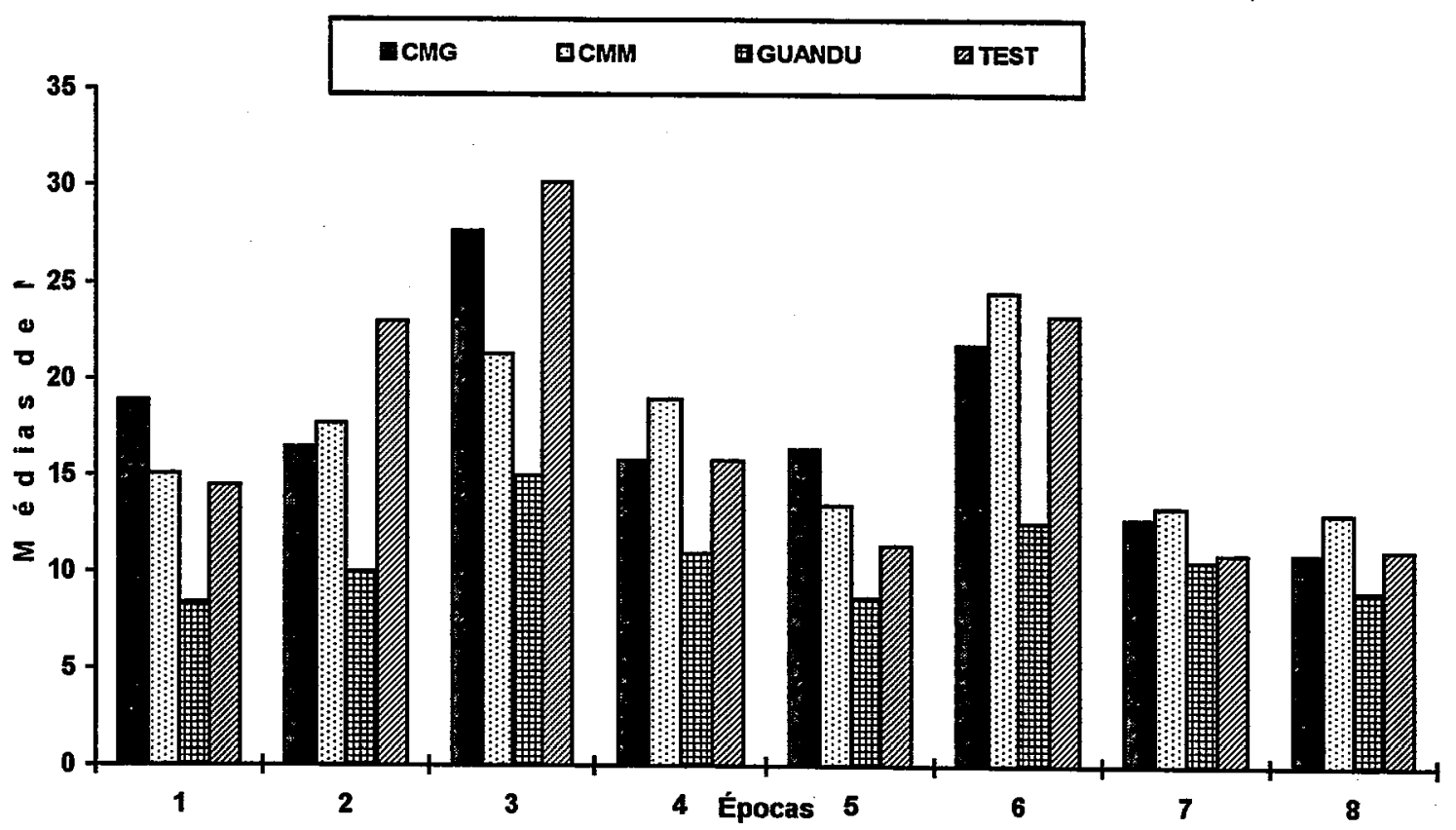

Figura 4. Disponibilidade do nitrogênio mineral nos tratamentos em relação as épocas de amostragens. Médias dos 8 períodos. 


\subsection{Teor de umidade no solo}

Os resultados das análises de teores de umidade do solo encontram-se na tabela 14.

Tabela 14. Análise da variância e teste F para os dados de \% de umidade no solo

\begin{tabular}{|c|c|c|c|c|}
\hline C.V. & GL & $\overline{\mathrm{QM}}$ & $\mathrm{F}$ & $\operatorname{Pr}>F$ \\
\hline Tratamentos & 3 & 21.7532 & 4.68 & $0.0359^{*}$ \\
\hline Resíduo (A) & 8 & 4.6432 & & \\
\hline Parcelas & 11 & & & \\
\hline Profundidade & 1 & 63.4110 & 117.46 & $0.0001^{*}$ \\
\hline Trat $x$ Prof & 3 & 4.6452 & 8.6046 & $0.0069 *$ \\
\hline Resíduo (B) & 8 & 0.5398 & & \\
\hline sub-parcelas & 12 & & & \\
\hline Época & 7 & 156.2817 & 138.53 & $0.0001^{*}$ \\
\hline Trat x Época & 21 & 2.4554 & 2.18 & $0.0049 *$ \\
\hline Prof x Época & 7 & 6.8590 & 6.08 & $0.0001 * *$ \\
\hline TratxProfxÉpo & 21 & 1.6427 & 1.46 & $0.1082 \mathrm{~ns}$ \\
\hline Resíduo (C ) & 112 & 1.1281 & & \\
\hline sub-suparc. & 168 & & & \\
\hline Total & 191 & & & \\
\hline
\end{tabular}

* : significativos ao $1 \%$

** : significativo ao $5 \%$ e não significativo ao $1 \%$

ns: não significativo 
Em relação a \% de umidade do solo podemos afirmar que houve diferença significativa entre os tratamentos ( tabela 15). Todos diferiram entre si, exceto o guandu ( guandu permanente) e a CMG (cobertura morta de guandu) que não diferiram entre si.

A testemunha é que apresenta a maior média ( $85.0 \%$ de umidade), diferindo das demais. $\mathrm{O}$ tratamento $\mathrm{CMM}$ (cobertura morta de mucuna) aparece com a menor média ( $83.4 \%$ de umidade), ver na tabela 15 .

Tabela 15. Comparação das médias do teor de umidade do solo segundo os tratamentos.

\begin{tabular}{lcc}
\hline \multicolumn{1}{c}{ Tratamentos } & Médias & Teste de Tukey \\
\hline Testemunha (solo nu) & 85.0 & $\mathrm{a}$ \\
Guandu (guandu permanente) & 84.4 & $\mathrm{~b}$ \\
CMG (cobertura morta de guandu) & 84.2 & $\mathrm{~b}$ \\
CMM (cobertura morta de mucuna-preta) & 83.4 & $\mathrm{c}$ \\
\hline
\end{tabular}

médias seguidas pela mesma letra nas colunas não diferem significativamente entre si pelo método de Tukey $(P>0.05)$.

Esses resultados discordam dos resultados obtidos por Derpsch et al.,(1983), Bragagnolo (1986), Unger \& McCalla, (1980) e Derpsch et al., (1985). Estes autores afirmam que a manutenção da resteva na superficie do solo, retém maior quantidade de água no solo.

Já em relação a umidade do solo nas diferentes profundidades houve diferença significativa ou seja as profundidades diferem entre si. 
As médias das $\%$ de umidade a $10 \mathrm{~cm}$ de profundidade sempre foram superior as médias de $30 \mathrm{~cm}$ (tabela 16). As médias da testemunha foram maiores e em segundo foi o guandu (guandu permanente) que a 10 e $30 \mathrm{~cm}$ de profundidade superou das CMG (cobertura morta de guandu) e CMM (cobertura morta de mucuna), e a $30 \mathrm{~cm}$ de profundidade se igualou a testemunha a qual sempre suas médias foram superiores (figura 6).

Ocorreu de fato o contrário do que afirma a literatura citada acima, a cobertura viva pode ter ganho por haver grande quantidade de palhada no solo e ainda as plantas promoveram uma drástica redução da temperatura do solo em relação a testemunha.

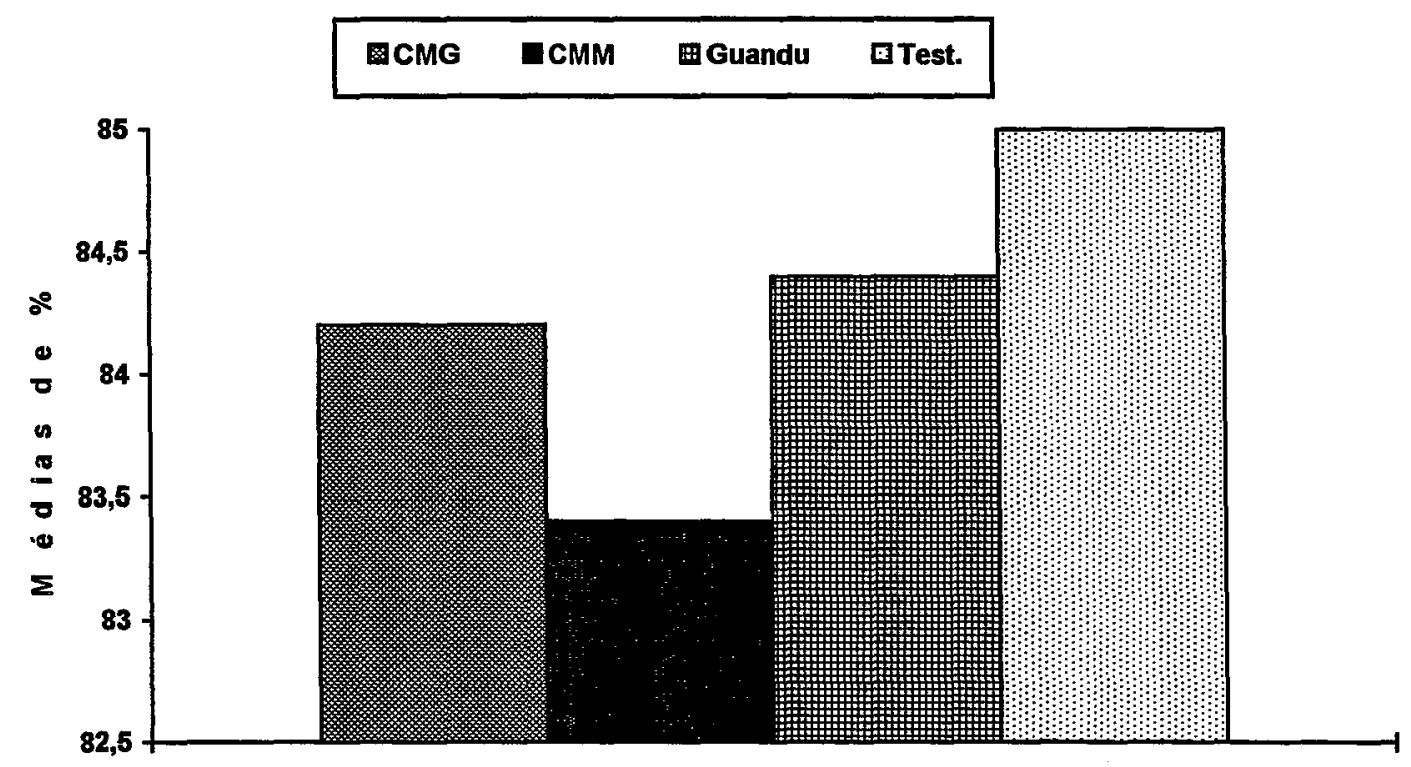

Tratamentos

Figura 5. Evolução das médias da \% de umidade segundo os tratamentos 
Tabela 16. Comparação das médias da \% umidade do solo segundo profundidade.

\begin{tabular}{ccc}
\hline Profundidade & médias & Teste de Tukey \\
\hline 10 & 84.8 & $\mathrm{a}$ \\
30 & 83.6 & $\mathrm{~b}$ \\
\hline
\end{tabular}

Médias seguidas pela mesma letra nas colunas não diferem significativamente entre si pelo método de Tukey $(P \geq 0.05)$.

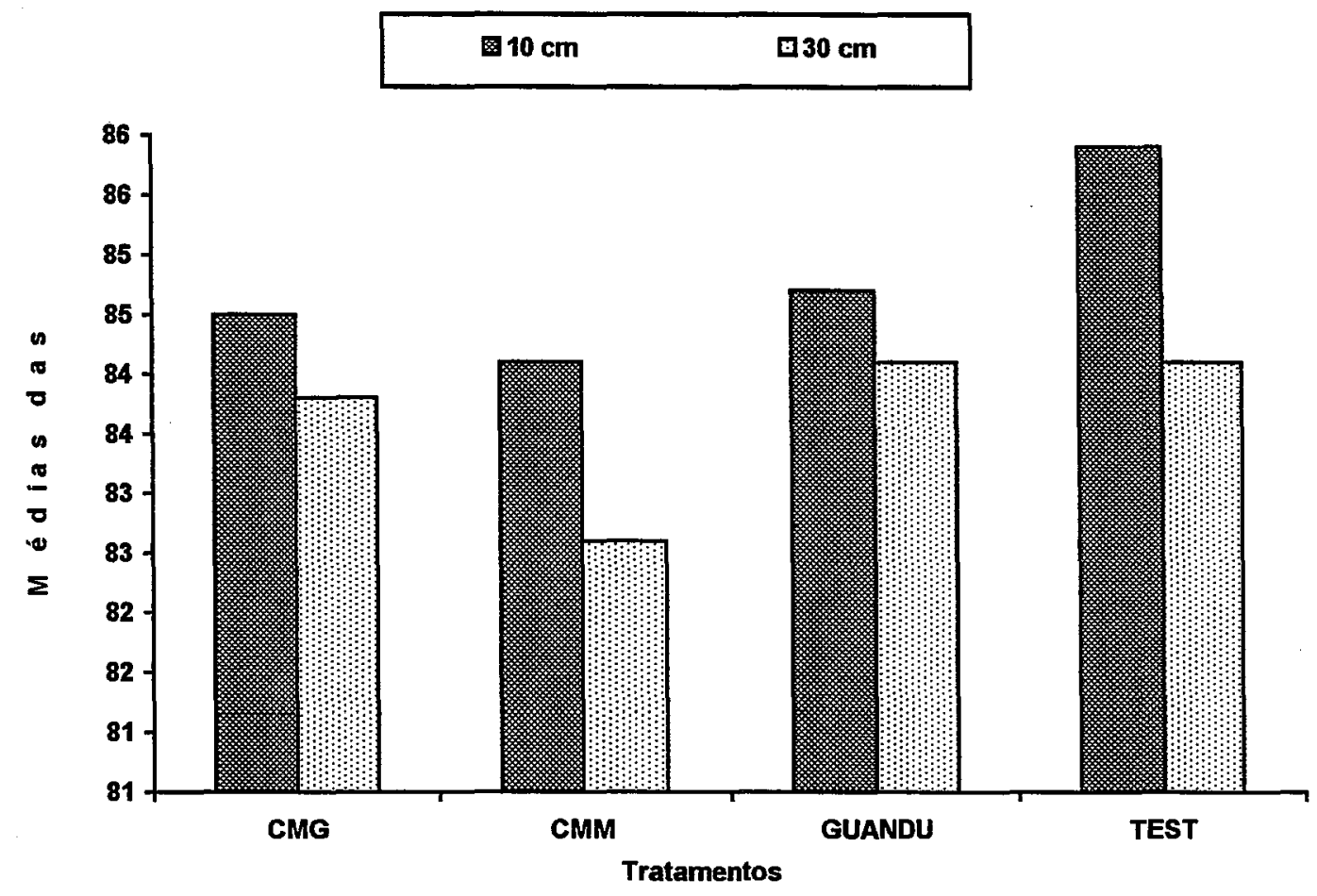

Figura 6. Evolução das médias das \% de umidade nos tratamentos segundo as profundidades. 
O estudo comparativo da umidade do solo de acordo com a época de amostragens se ilustra na tabela 17 e a evolução dos teores de umidade do solo estão na figura 7.

Tabela 17. Comparar as médias da umidade do solo segundo épocas .

\begin{tabular}{lcc}
\hline Épocas & médias & Teste Tukey \\
\hline 1 - julho & 84.5 & $\mathrm{a}$ \\
2 - agosto & 86.2 & $\mathrm{~b}$ \\
3 - setembro & 87.0 & $\mathrm{c} \mathrm{b}$ \\
4 - outubro & 83.5 & $\mathrm{~d}$ \\
5 - novembro & 83.4 & $\mathrm{~d}$ \\
6 - dezembro & 87.4 & $\mathrm{e}$ \\
7 - janeiro & 81.4 & $\mathrm{f}$ \\
8 - fevereiro & 80.4 & $\mathrm{~g}$ \\
\hline
\end{tabular}

médias seguidas pela mesma letra nas colunas não diferem significativamente entre si pelo método de Tukey ( $P \geq 0.05$ ).

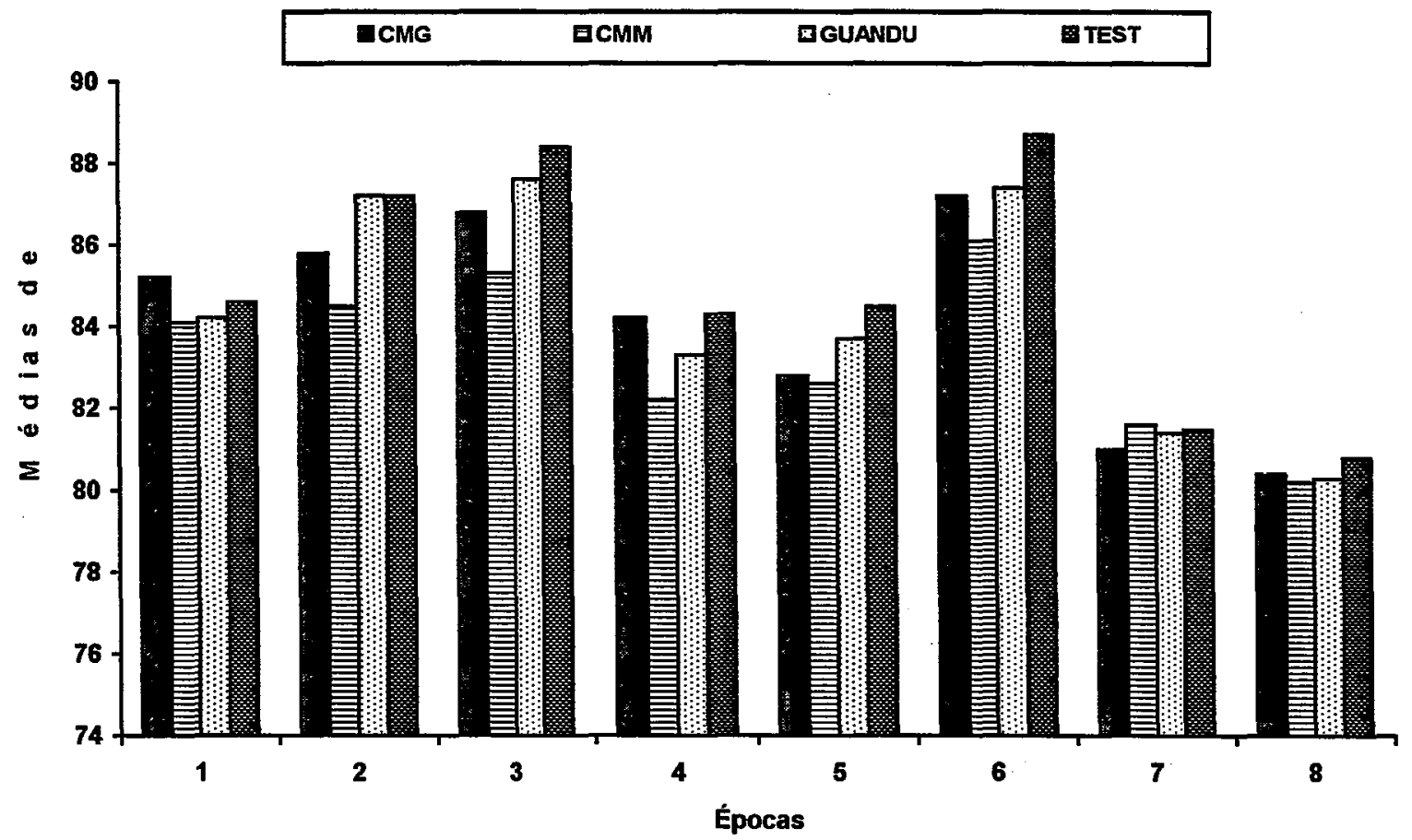

Figura 7. Evolução das médias dos teores de umidade do solo nos tratamentos segundo as épocas. 
Houve diferença significativa entre épocas, sendo a maior média na época 3 e 6, a menor na época 8 .

A testemunha apresentou maior média na épocas $3,5,6$ e 8 . O CMM (cobertura morta de mucuna) apresentou as menores médias em todas as épocas, exceto na 7 e 8.

Em todos os testes a testemunha sempre foi superior aos demais tratamentos ou seja houve maior umidade na testemunha.

Nas profundidades a $10 \mathrm{~cm}$ do solo também a testemunha superou os demais, mais a $30 \mathrm{~cm}$ de profundidade o guandu permanente se igualou a testemunha ou seja o teor de umidade foi igual, provavelmente o guandu requereu mais água na camada superficial do solo, devido a distribuição de raízes superficiais existente nessa região. Mas a $30 \mathrm{~cm}$ não ocorreu a competição por água, mas abaixo do guandu permanente existe uma grande quantidade de palha $\mathrm{e}$ a temperatura esteve sempre abaixo dos demais tratamentos, enquanto as coberturas mortas foram sempre inferior em relação á umidade isso pode ser explicado devido à menor cobertura proporcionada por seus resíduos e também por ser um solo tropical, onde a energia radiante chega até a terra com grande intensidade e os resíduos vão se decompondo rapidamente. 


\subsection{Teor de nitrogênio nas plantas de seringueira}

Os teores de nitrogênio iniciais nas plantas de seringueira estão nas tabelas 18 e 19 e o nitrogênio final das plantas se ilustram nas tabelas 20 e 21 .

Tabela 18. Análise da variância para nitrogênio inicial da folha

\begin{tabular}{lcccc}
\hline C.V. & GL & QM & F & Pr > F \\
\hline Tratamentos & 3 & 0.1879 & 0.77 & $0.5441 \mathrm{~ns}$ \\
Resíduo & 8 & 0.2451 & & \\
& & & & \\
\hline Total & 11 & & & \\
\hline
\end{tabular}

ns. não existe diferença significativa entre tratamentos

Tabela 19. Comparação de médias do nitrogênio inicial das folhas de seringueira

\begin{tabular}{lcc}
\hline \multicolumn{1}{c}{ Tratamentos } & médias & Teste de Tukey \\
\hline CMG (cobertura morta de guandu) & 3.6 & $\mathrm{a}$ \\
CMM (cobertura morta de mucuna-preta) & 3.5 & $\mathrm{a}$ \\
Guandu (guandu permanente) & 3.2 & $\mathrm{a}$ \\
Testemunha (solo nu) & 3.2 & $\mathrm{a}$ \\
\hline médias seguidas pela mesma letra não diferem significativamente entre si pelo \\
método de Tukey ( $\mathrm{P} \geq 0.05$ ).
\end{tabular}


Tabela 20. Análise da variância para nitrogênio final da folha de seringueira

\begin{tabular}{lcccc}
\hline C.V. & GL & QM & F & Pr $>$ F \\
\hline Tratamentos & 3 & 0.1454 & 0.18 & $0.9080 \mathrm{~ns}$ \\
Resíduo & 8 & 0.8148 & & \\
& & & & \\
\hline Total & 11 & & & \\
\hline
\end{tabular}

ns. não existe diferença significativa entre tratamentos

Tabela 21. Comparação das médias de nitrogênio final das folhas de seringueira

\begin{tabular}{lcc}
\hline Tratamentos & médias & Teste Tukey \\
\hline CMG (cobertura morta de guandu) & 3.6 & $\mathrm{a}$ \\
CMM (cobertura morta de mucuna-preta) & 3.5 & $\mathrm{a}$ \\
Guandu (guandu permanente) & 3.2 & $\mathrm{a}$ \\
Testemunha (solo nu) & 3.2 & $\mathrm{a}$ \\
\hline Médias seguidas pela mesmas letras não diferem & significativamente entre si pelo \\
método de Tukey à $5 \%$. & &
\end{tabular}

Não houve diferença significativa entre os tratamentos, a época inicial e final do experimento e comparação entre a época inicial e final . Mas foi observado que o teor de nitrogênio nas folhas de seringueira na instalação do experimento era de $3.70 \%$ de $\mathrm{N}$ (tabela 6), e no início da coleta de dados em julho de 1995 e final em fevereiro de 1996 o teor de $\mathrm{N}$ manteve-se estável . Na testemunha e guandu permanente o teor foi muito pouco menor $(3.20 \%)$ e não diferindo estatisticamente. Isso mostra que o guandu permanente não concorreu com o desenvolvimento da seringueira . 


\subsection{Temperaturas mínimas e máximas do solo}

Primeiramente será discutida os registros de temperatura mínima ( tabela 22 a 25 ) e posteriormente os de temperatura máxima (tabela 26 e 29).

Tabela 22. Análise da variância e Teste F para os dados de temperatura mínima do solo

\begin{tabular}{|c|c|c|c|c|}
\hline C.V & GL & $\overline{Q M}$ & F & $\operatorname{Pr}>F$ \\
\hline tratamentos & 3 & 150.3710 & 32.02 & $0.0001 *$ \\
\hline resíduo (A) & 20 & 4.6952 & & \\
\hline Parcelas & 23 & & & \\
\hline Profundidade & 4 & 378.9396 & 293.77 & $0.0001^{*}$ \\
\hline Trat $x$ Prof & 12 & 3.22057 & 2.50 & $0.0078^{*}$ \\
\hline resíduo (B) & 80 & 1.2899 & & \\
\hline sub-parcela & 96 & & & \\
\hline Época & 7 & 1020.7383 & 629.00 & $0.0001 *$ \\
\hline trat $x$ época & 21 & 10.8426 & 6.68 & $0.0001^{*}$ \\
\hline prof $x$ época & 28 & 10.27946 & 6.33 & $0.0001^{*}$ \\
\hline Trat $\mathbf{x}$ prof $\mathbf{x}$ & 84 & 2.14586 & 1.32 & 0.0347 \\
\hline épo & 700 & 1.6228 & & \\
\hline \multicolumn{5}{|l|}{ resíduo ( C ) } \\
\hline sub-sub-parcela & 840 & & & \\
\hline Total & 959 & & & \\
\hline
\end{tabular}

$(*)$ altamente significativo a $5 \%$ 
As temperaturas mínimas sempre foram registradas no tratamento de guandu permanente, e em relação as diferentes profundidades a $2 \mathrm{~cm}$ do solo também foi menor, e a época que obteve menor temperatura foi a 1 (julho ) no tratamento testemunha (solo $\mathrm{nu}$ ) onde a temperatura mais baixa registrada durante todo o período do experimento foi de $10.2^{\circ} \mathrm{C}$.

De acordo com Zong Dao \& Xuequin, citado por Ortolani (1987), dois valores extremos para o desenvolvimento da seringueira é a $10^{\circ} \mathrm{C}$ quando a fotossíntese é praticamente nula e a máxima de $40^{\circ} \mathrm{C}$ quando a taxa de respiração é maior que a taxa da fotossíntese. Esses extremos prejudicam não somente o desenvolvimento da seringueira como também de todas as outras plantas.

A mínima para o guandu a $2 \mathrm{~cm}$ de profundidade foi de $12.2^{\circ} \mathrm{C}$ em julho e o maior valor encontrado para a mínima do mesmo tratamento foi de $21.6^{\circ} \mathrm{C}$ no mês de fevereiro. Para a testemunha a mínima encontrada na profundidade de $2 \mathrm{~cm}$ foi de $10.2^{\circ} \mathrm{C}$ e e o maior valor encontrado para a mínima do mesmo tratamento foi $25.4^{\circ} \mathrm{C}$, enquanto nos tratamentos $\mathrm{CMG}$ e $\mathrm{CMM}$ a temperatura mínima não variou muito entre ambos, ficando a mínima a $2 \mathrm{~cm}$ de profundidade a $11.2^{\circ} \mathrm{C}$ em julho e a máxima da mínima foi de $23.2^{\circ} \mathrm{C}$ em janeiro na mesma profundidade.

A temperatura variou em todas as profundidades, sendo para a temperatura mínima na profundidade $2 \mathrm{~cm}$ sempre foi menor, apresentando um aumento crescente a medida que vai se aprofundando no solo. Também com a mudança da estações do ano a temperatura mínima foi se alterando.

Em relação a temperatura máxima do solo foi diferentes em todos os tratamentos, a testemunha sempre foi bem maior comparada com as demais $\left(43.8^{\circ} \mathrm{C}\right.$ em novembro de 1995 a $2 \mathrm{~cm}$ de profundidade). $O$ guandu permanente foi o tratamento que obteve sempre a menor máxima de $25.2^{\circ} \mathrm{C}$ a $2 \mathrm{~cm}$ de 
profundidade . A CMG e CMM obtiveram em média uma temperatura máxima de $24^{\circ} \mathrm{C}$.

Mesmo a $10 \mathrm{~cm}$ de profundidade do solo no tratamento testemunha foram encontrada temperatura de $34.2^{\circ} \mathrm{C}$ no mês de janeiro, o de acordo com Döbereiner \& Aronovich (1966); prejudica a nodulação das leguminosa e Sichmann (1977), diz que temperatura acima de $33^{\circ} \mathrm{C}$ prejudica na absorção de nitrogênio.

De acordo com Bragagnolo \& Mielniczuk (1990), Unger \& McCalla (1980); Derpsch et al.,(1983); Medcalf (1956); Sidiras \& Pavan (1985); Lal (1974 ); Derpsch et al., (1985); a cobertura da superfície com cobertura morta ou verde evita o aquecimento excessivo do solo, aquecimento esse que prejudica no crescimento e desenvolvimento do sistema radicular, absorção de íons e água ( Epstein, 1972) e as atividades microbiológicas do solo (Voss \& Sidiras, 1985); Dart \& Mercer (1965); Dart et al., (1976).

Foi verificado que em períodos quentes no tratamento guandu permanente houve diferença de até $18^{\circ} \mathrm{C}$ em comparação com a testemunha, fato que também foi constatado por Derpsch et al.,(1983). 
Tabela 23. Comparação de médias da temperatura mínima do solo segundo os tratamentos

\begin{tabular}{lcc}
\hline Tratamentos & médias & Teste Tukey \\
\hline CMG & 20.3 & $\mathrm{a}$ \\
CMM & 20.8 & $\mathrm{a}$ \\
Guandu & 19.5 & $\mathrm{~b}$ \\
Testemunha & 21.3 & $\mathrm{c}$
\end{tabular}

médias seguidas pela mesma letra não diferem estatisticamente entre si pelo método de Tukey a $5 \%$.

Conclusões:

1) Existe diferença significativa a $5 \%$ entre os tratamentos

- observe que a maior média é da testemunha

- as médias das temperaturas mínimas da testemunha e os outros tratamentos são diferentes

- não existe diferença significativa a $5 \%$ entre as temperaturas mínimas médias de $C M G$ e CMM.

- no guandu a temperatura mínima foi sempre menor que os demais tratamentos. 
A evolução da temperatura mínima do solo para o diferentes tratamentos são apresentados na figura 8 .

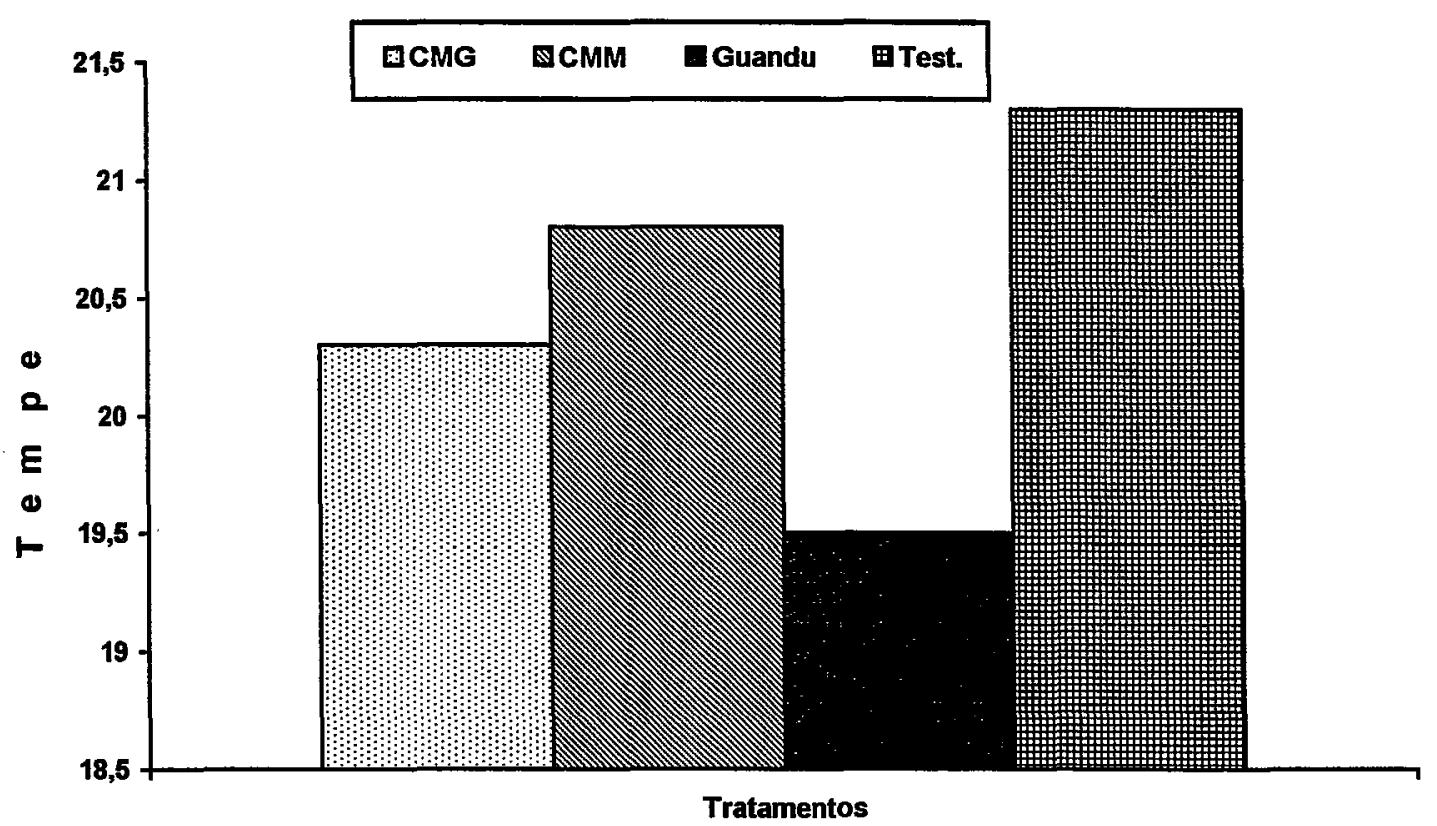

Figura 8. Evolução das médias das temperatura mínima do solo segundos os tratamentos. 
Tabela 24. Comparação das médias da temperatura mínima do solo segundo as profundidades.

\begin{tabular}{ccc}
\hline Profundidades & médias & Teste Tukey \\
\hline 2 & 18.5 & $\mathrm{a}$ \\
5 & 19.7 & $\mathrm{~b}$ \\
10 & 20.7 & $\mathrm{c}$ \\
20 & 21.5 & $\mathrm{~d}$ \\
30 & 21.9 & $\mathrm{e}$
\end{tabular}

médias seguidas pela mesma letra não diferem entre si pelo método de Tukey a $5 \%$.

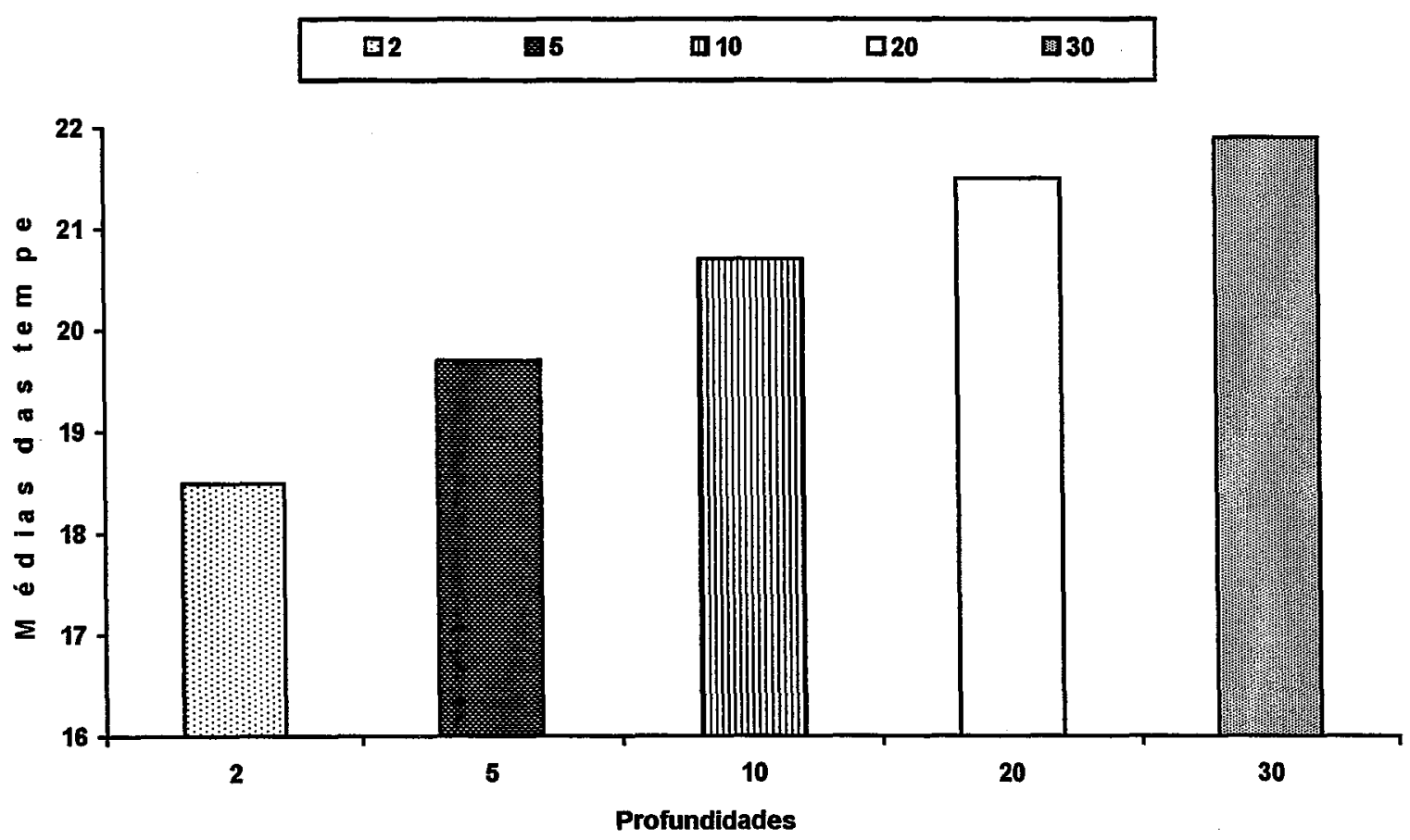

Figura 9. Evolução das médias da temperatura mínima do solo segundo as profundidades. 
Existe diferença significativa a $5 \%$ entre as profundidades ou seja o efeito das profundidades é significativamente diferente na temperatura média mínima.

A maior média foi na profundidade de $30 \mathrm{~cm}$ e a temperatura média mínima foi de $21.98^{\circ} \mathrm{C}$.

Na profundidade de $2 \mathrm{~cm}$ a temperatura média mínima foi de $18.54^{\circ} \mathrm{C}$.

Todos são significativamente diferentes entre si.

Tabela 25. Comparação das médias da temperatura mínima do solo em relação as épocas .

\begin{tabular}{ccc}
\hline Época & médias & Teste de Tukey \\
\hline 1 & 16.0 & $\mathrm{a}$ \\
2 & 17.8 & $\mathrm{~b}$ \\
3 & 19.0 & $\mathrm{c}$ \\
4 & 19.3 & $\mathrm{c}$ \\
5 & 20.6 & $\mathrm{~d}$ \\
6 & 23.4 & $\mathrm{e}$ \\
7 & 23.7 & $\mathrm{e}$ \\
8 & 23.7 & $\mathrm{e}$ \\
\hline médias seguidas pela mesma letra não diferem significativa entre si pelo método \\
de Tukey ( $\mathrm{P} \geq 0.05$ ).
\end{tabular}

Existe diferença significativa entre as épocas ou o efeito da época é significativamente diferente na temperatura média mínima. 
Existe diferença significativa entre as temperaturas médias mínimas das épocas

1 versos $2,3,4,5,6,7,8$

2 versos as outras épocas

3 versos $5,6,7,8$

Existe diferença significativa a $5 \%$ entre as épocas:

3 versos 4 ; e 6,7 e 8 .

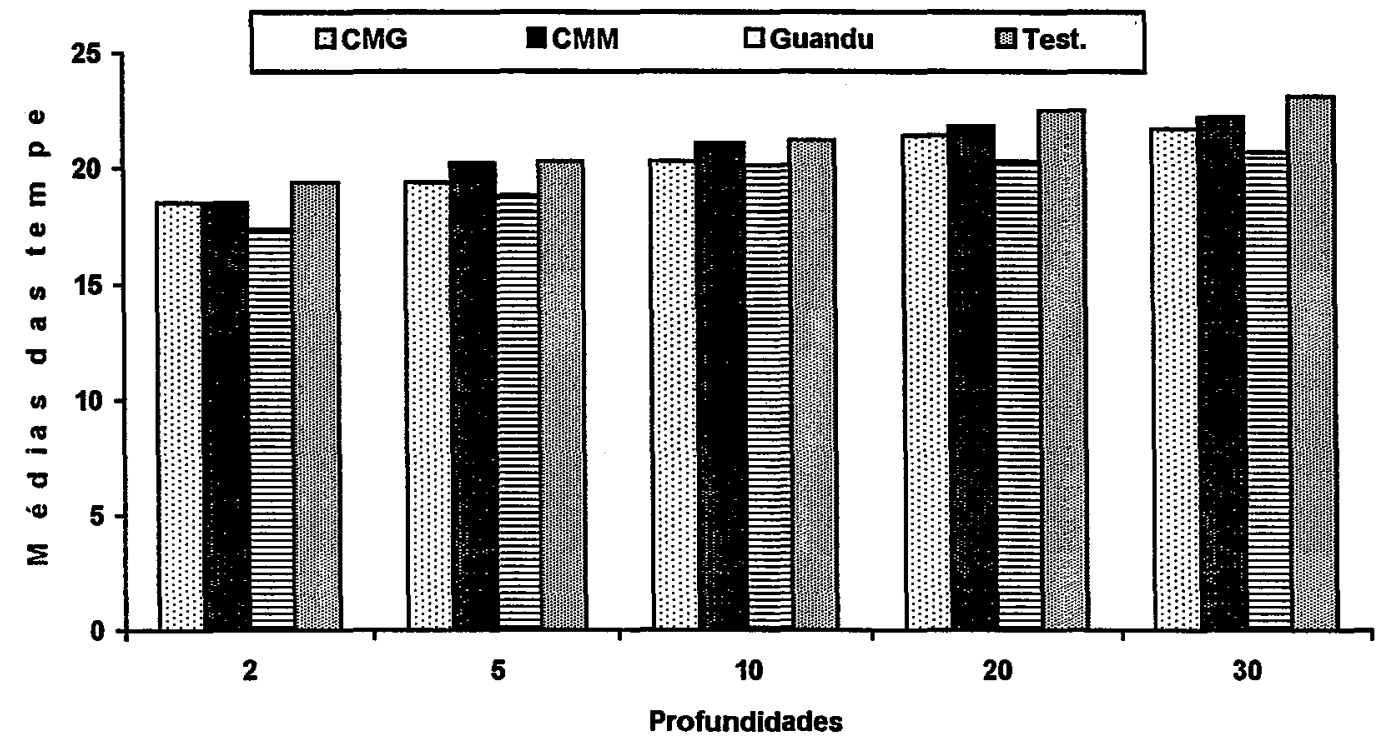

Figura 10. Evolução das médias da temperatura mínima do solo segundo interação tratamento $\mathrm{x}$ profundidade.

Existe interação entre tratamentos e profundidades. 
Nota-se que sempre o desempenho da testemunha é maior nas diferentes profundidades (figura 11).

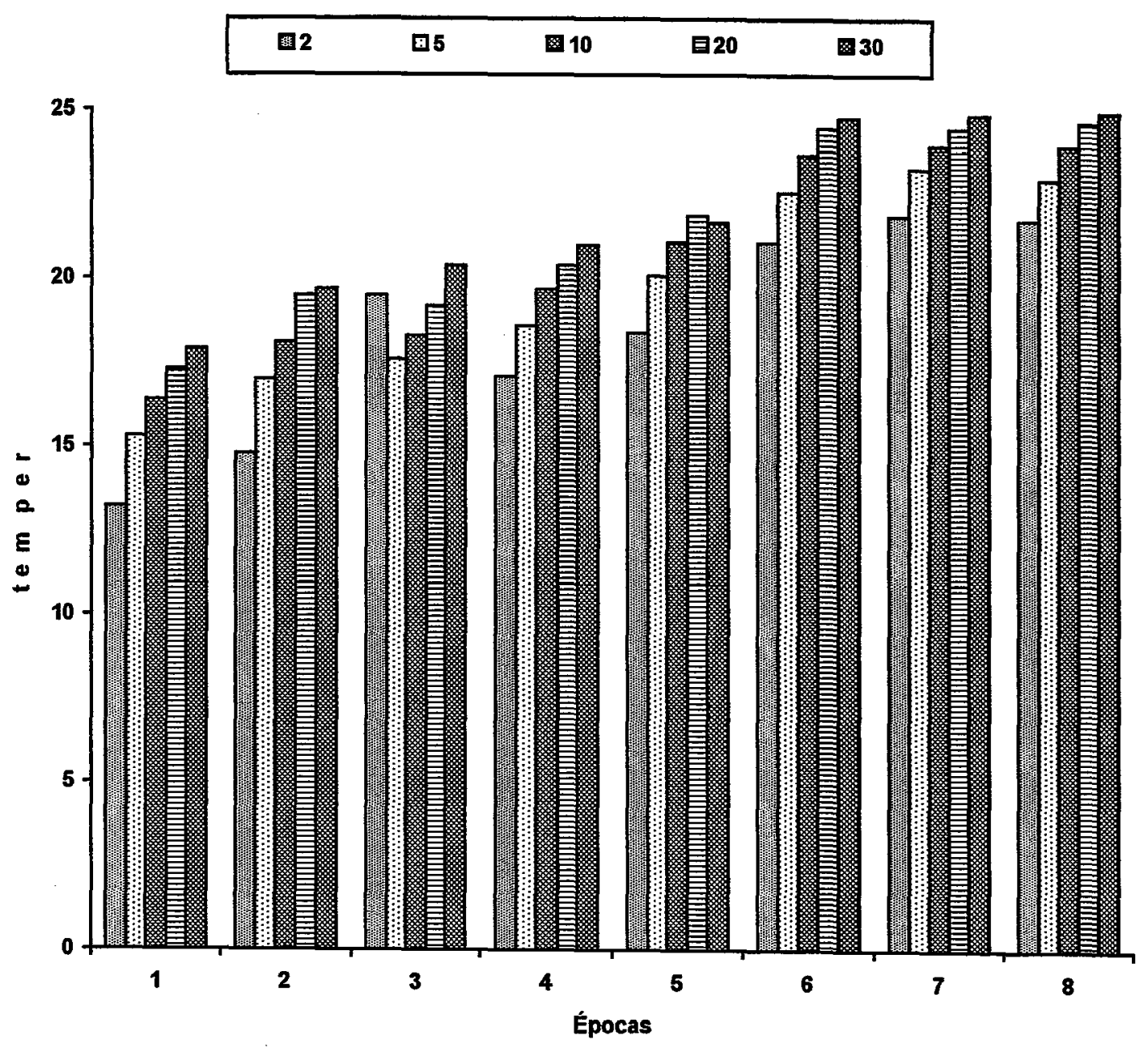

Figura 11. Comparação das médias da temperatura mínima do solo segundo interação Profundidade x Época.

Existe interação entre profundidades $\mathrm{x}$ épocas. 
Tabela 26. Análise da variância e Teste $\mathrm{F}$ para os dados de temperatura máxima do solo.

\begin{tabular}{lcccc}
\hline C.V. & GL & QM & F & Pr $>F$ \\
\hline Tratamentos & 3 & 1826.884 & 198.42 & $0.0001^{*}$ \\
resíduo (a) & 20 & 9.207 & & \\
\hline Parcelas & 23 & & & \\
\hline Profundidade & 4 & 594.1883 & 283.27 & $0.0001^{*}$ \\
trat x prof & 12 & 125.1218 & 59.65 & $0.0001^{*}$ \\
resíduo (b) & 80 & 2.0976 & & \\
\hline sub - parcela & 96 & & & $0.0001^{*}$ \\
\hline Época & 7 & 1056.443 & 225.69 & $0.0001^{*}$ \\
trat x época & 21 & 46.809 & 10.00 & $0.0001^{*}$ \\
prof x época & 28 & 41.802 & 8.93 & 0.0033 \\
trat x prof x ép & 84 & 7.0836 & 1.51 & \\
resíduo ( c ) & 700 & 4.6789 & & \\
\hline Sub-sub-parcela & 840 & & & \\
\hline Total & 956 & & & \\
\hline (*) altamente significativo a 5\%. & & & & \\
\hline
\end{tabular}

Existe diferença significativa entre os tratamentos. 
Tabela 27. Comparação de médias de temperatura máxima do solo segundo os tratamentos.

\begin{tabular}{lcc}
\hline \multicolumn{1}{c}{ Tratamentos } & Médias & Teste de Tukey \\
\hline CMG (cobertura morta de guandu) & 23.9 & a \\
CMM (cobertura morta de mucuna-preta) & 24.1 & a \\
Guandu (guandu permanente) & 20.9 & b \\
Testemunha (solo nu) & 27.6 & $\mathrm{c}$ \\
\hline médias seguidas pela mesma letra não diferem estatisticamente entre si pelo \\
método de Tukey a 5\%.
\end{tabular}

A temperatura média máxima da testemunha é a maior de todas; e é significativamente diferente das demais ao $5 \%$ de significância .

Não existe diferença significativa a $5 \%$ entre temperatura média máxima de $\mathrm{CMG}$ e CMM.

A temperatura média máxima do guandu sempre foi a menor em relação as demais. 


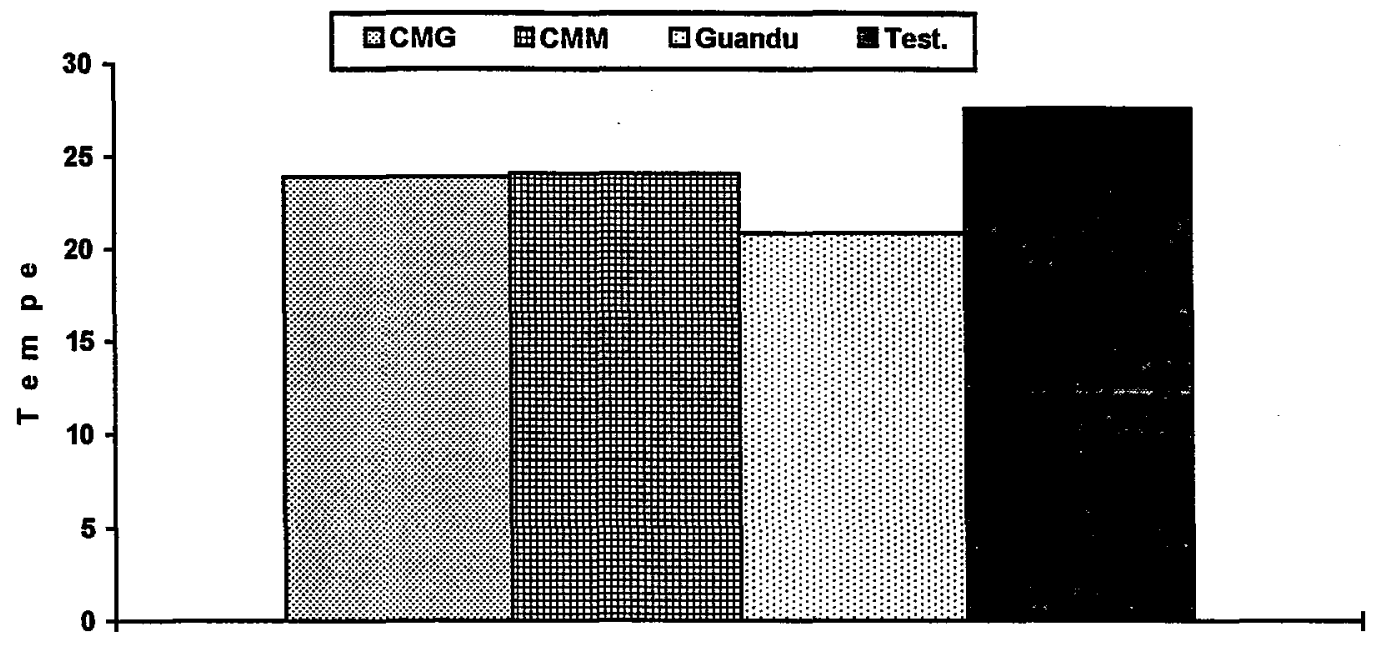

Tratamentos

Figura 12. Evolução das médias das temperaturas máximas do solo em relação aos tratamentos.

Tabela 28. Comparação de médias das temperaturas máximas do solo segundo as profundidades.

\begin{tabular}{ccc}
\hline Profundidades & Médias & Teste de Tukey \\
\hline 2 & 26.0 & a \\
5 & 25.8 & a \\
10 & 23.9 & b \\
20 & 22.6 & c \\
30 & 22.2 & c \\
\hline Médias seguidas por letras distintas diferem entre si mediante Teste de Tukey a \\
5 \% de significância.
\end{tabular}


Existe diferença significativa à $5 \%$ entre as profundidades.

São significativamente diferentes as profundidades: 2 versos 10 ;

2 vs 20 e 30; 2 e 5 não são significativamente diferentes .

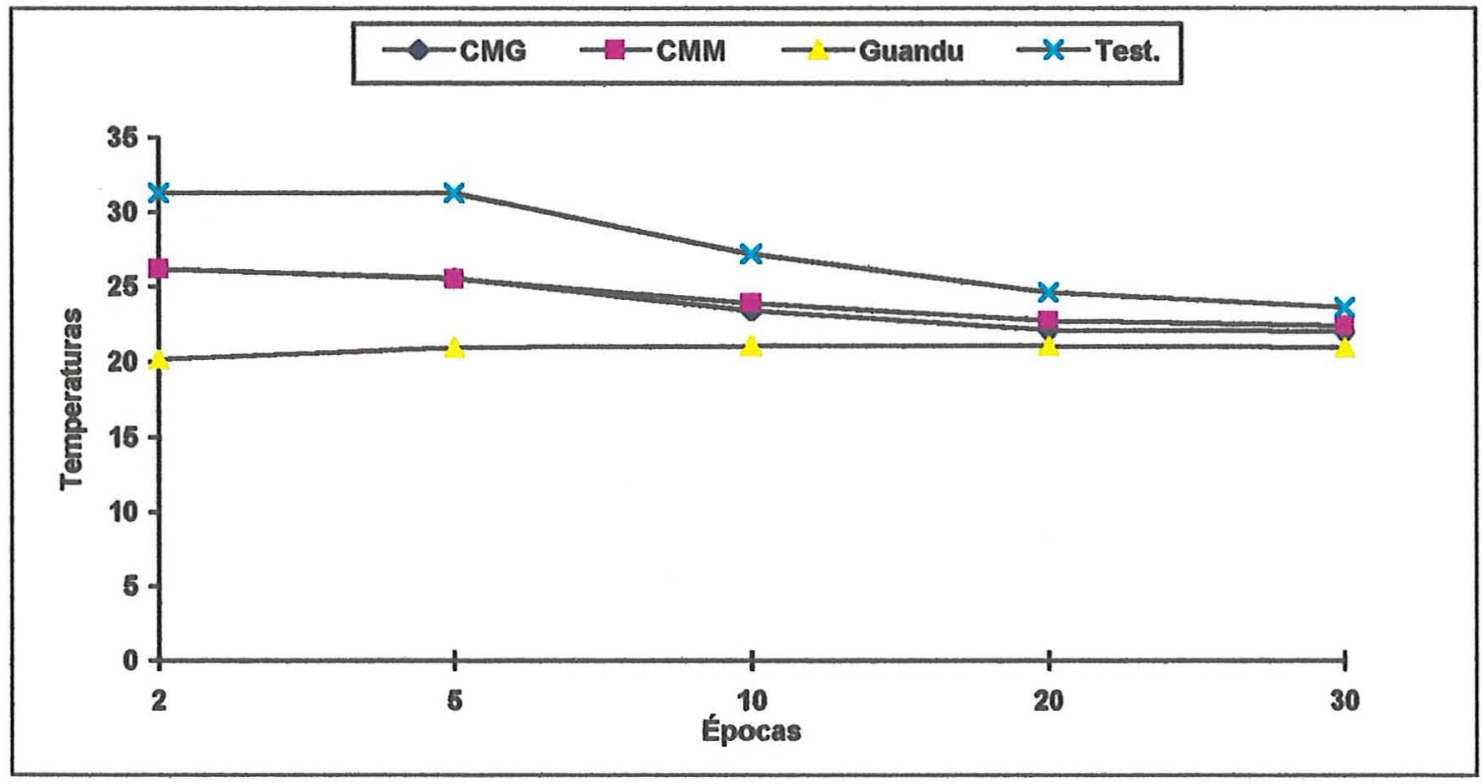

Figura 13. Evolução das médias das temperaturas máximas do solo em relação aos tratamentos segundo as diferentes profundidades. 
Tabela 29. Comparação das médias da temperatura máxima do solo em relação aos tratamentos segundo as épocas.

\begin{tabular}{ccc}
\hline Épocas & Médias & Teste de Tukey \\
\hline 1 & 19.0 & a \\
2 & 22.2 & b \\
3 & 22.0 & b \\
4 & 23.8 & c \\
5 & 24.5 & c \\
6 & 26.4 & d \\
7 & 27.4 & e \\
8 & 27.4 & e
\end{tabular}

Médias seguidas pela mesma letra não diferem significativamente entre si pelo método de Tukey a $5 \%$.

Existe diferença significativa entre épocas à $5 \%$.

A temperatura média máxima da época 1 é diferente das outras;

Não são significativamente diferentes as épocas 2 versos 3 ;

4 e $5 ; 7$ e 8

A temperatura média máxima da época 6 é diferente de todas as demais; 


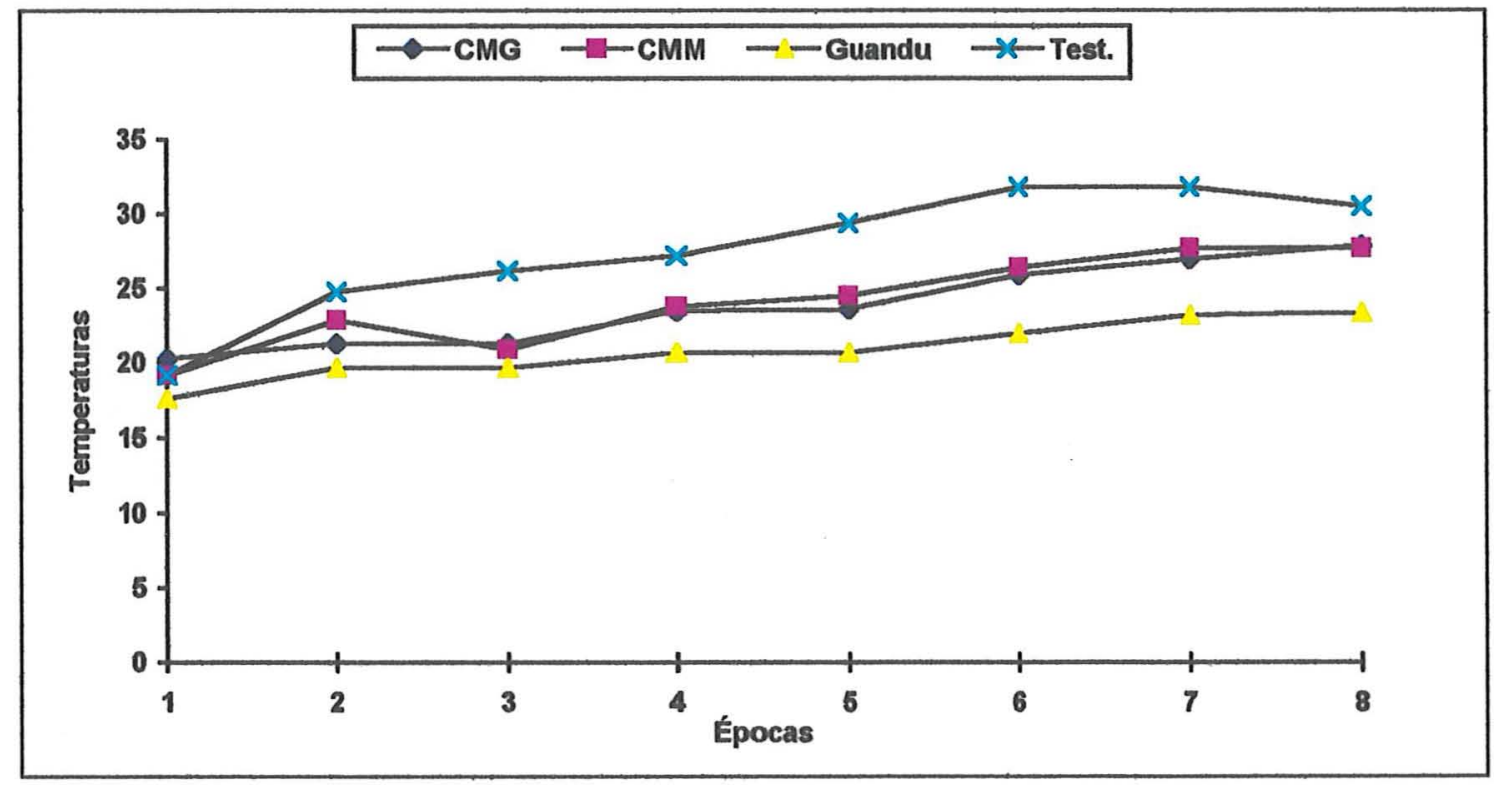

Figura 14. Evolução das médias das temperaturas máximas do solo em relação aos tratamentos segundo as épocas.

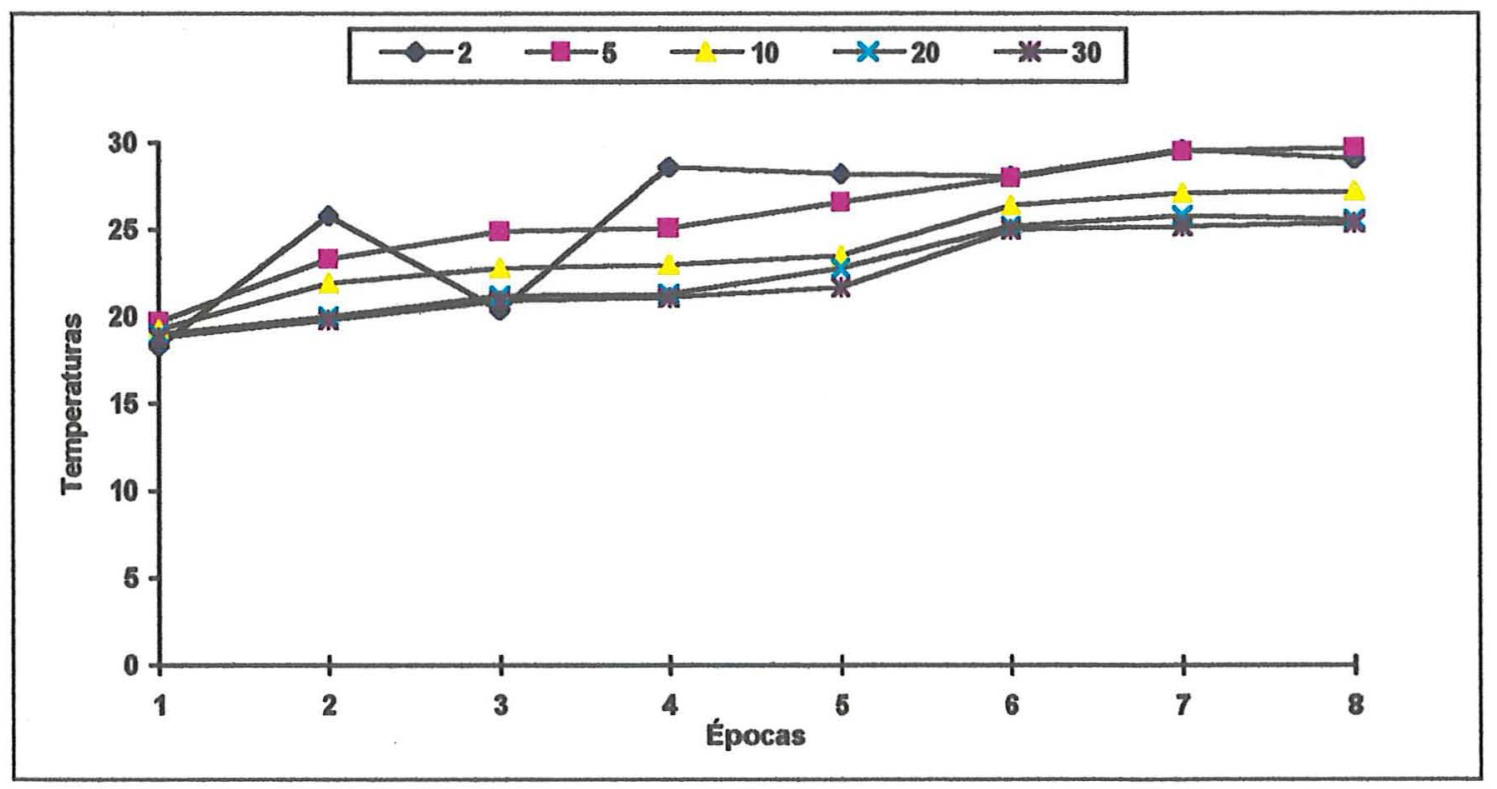

Figura 15. Evolução das médias das temperaturas máximas do solo em relação as profundidades segundo as épocas. 
As figuras e as tabelas a seguir são das temperaturas mínimas e máximas do solo obtidas durante as oito épocas.

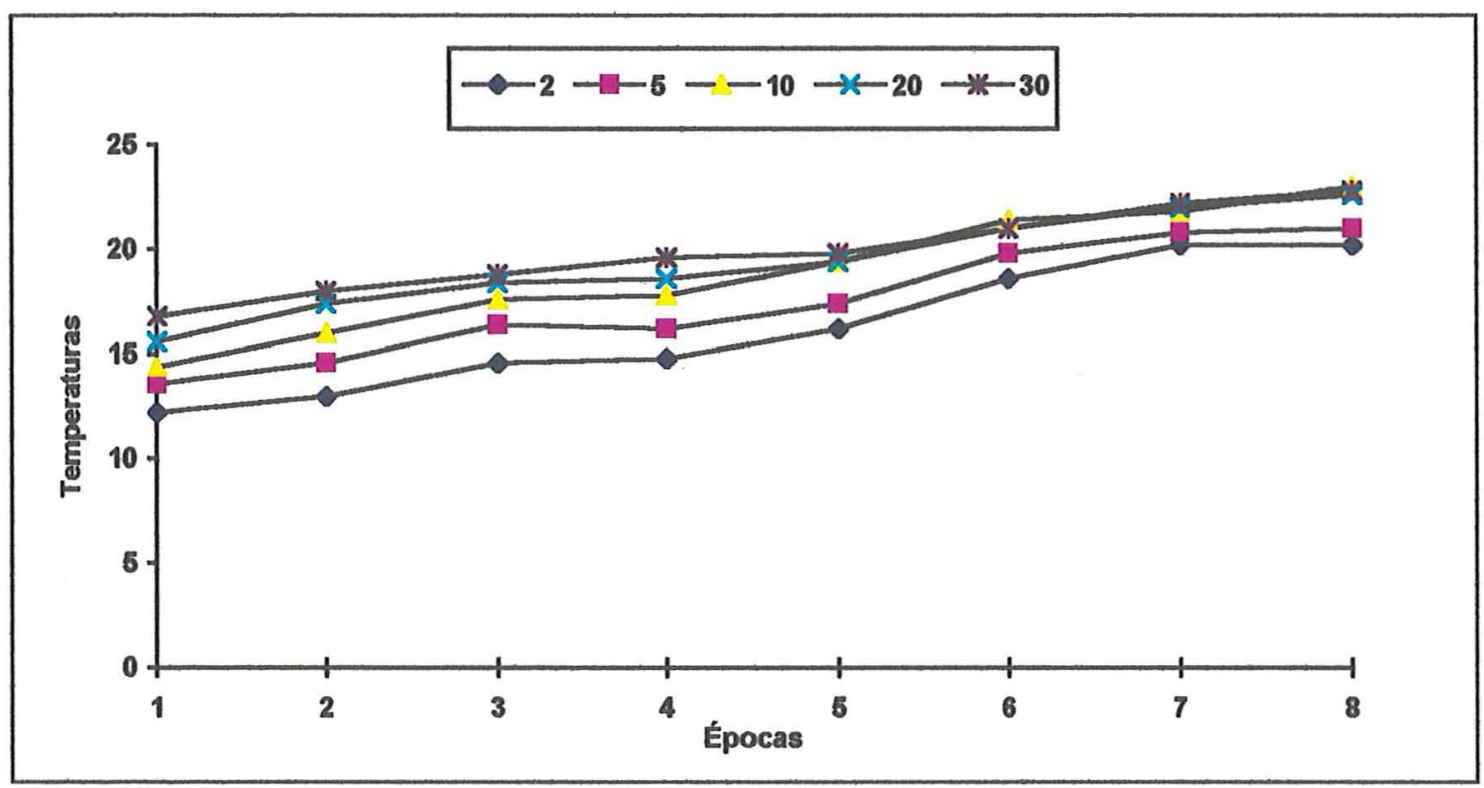

Figura 16. Evolução das temperaturas mínimas do solo nas diferentes profundidades para o tratamento guandu (guandu permanente), durante os 8 períodos.

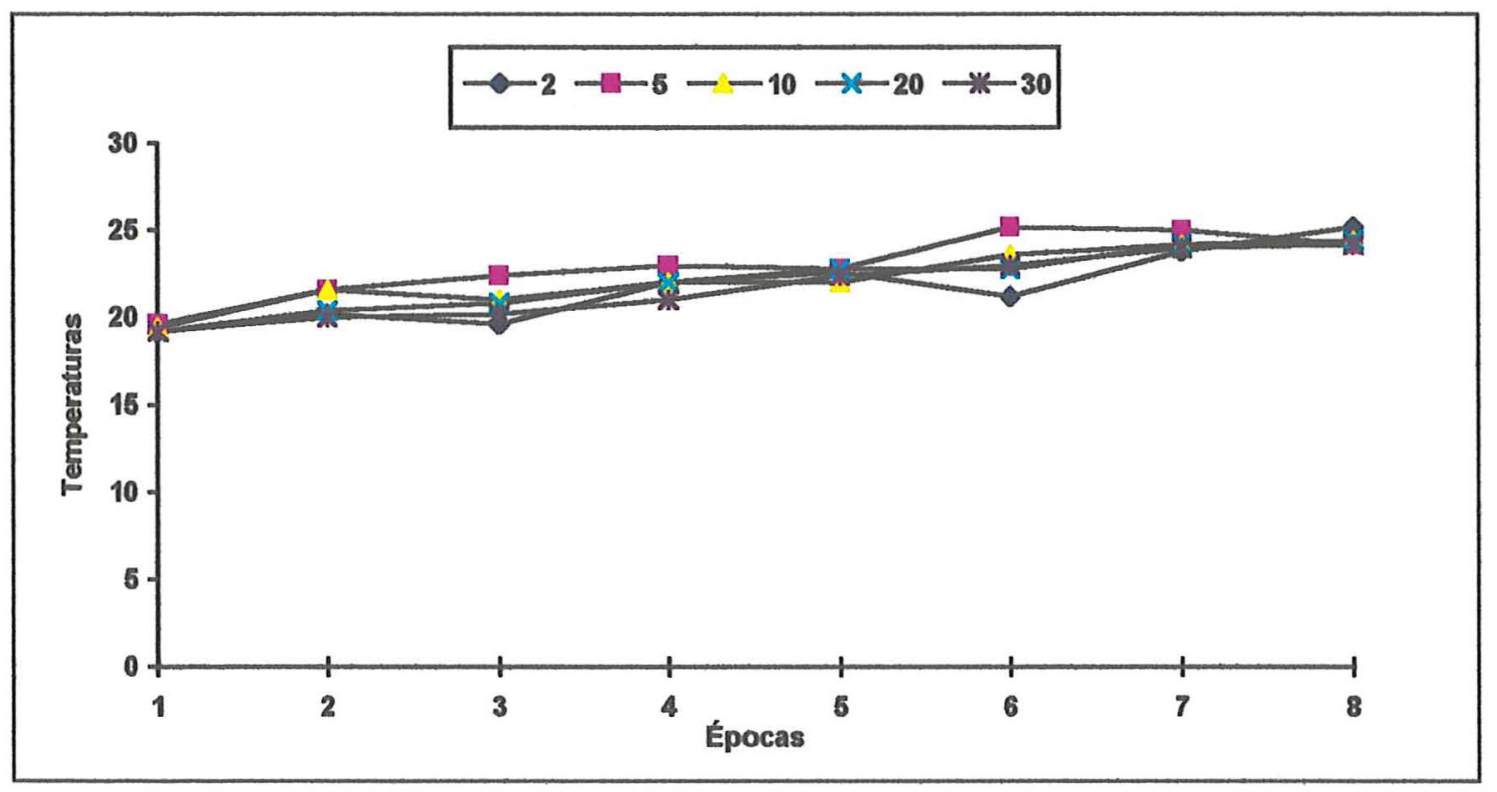

Figura 17. Evolução das temperaturas máximas do solo nas diferentes profundidades para o tratamento guandu (guandu permanente) durante os 8 períodos. 
Tabela 30. Dados da temperatura mínima e máxima do solo para o tratamento guandu (guandu permanente), durante os 8 períodos .

Temperatura mínima do solo para o tratamento guandu (guandu permanente)

\begin{tabular}{lccccccccc}
\hline tratam. & prof. & 1 & 2 & 3 & 4 & 5 & 6 & 7 & 8 \\
\hline guandu & 2 & 12.2 & 13.0 & 14.6 & 14.8 & 16.2 & 18.6 & 20.2 & 20.2 \\
guandu & 5 & 13.6 & 14.6 & 16.4 & 16.2 & 17.4 & 19.8 & 20.8 & 21.0 \\
guandu & 10 & 14.4 & 16.0 & 17.6 & 17.8 & 19.4 & 21.4 & 21.8 & 23.0 \\
guandu & 20 & 15.6 & 17.4 & 18.4 & 18.6 & 19.4 & 21.0 & 22.0 & 22.6 \\
guandu & 30 & 16.8 & 18.0 & 18.8 & 19.6 & 19.8 & 21.0 & 22.2 & 22.8 \\
\hline
\end{tabular}

Temperatura máxima do solo para o tratamento guandu (guandu permanente)

\begin{tabular}{lccccccccc}
\hline tratam. & Prof. & 1 & 2 & 3 & 4 & 5 & 6 & 7 & 8 \\
\hline guandu & 2 & 19.2 & 20.2 & 19.6 & 22.0 & 22.6 & 21.2 & 23.8 & 25.2 \\
guandu & 5 & 19.6 & 21.6 & 22.4 & 23.0 & 22.8 & 25.2 & 25.0 & 24.2 \\
guandu & 10 & 19.4 & 21.6 & 21.0 & 22.0 & 22.0 & 23.6 & 24.2 & 24.4 \\
guandu & 20 & 19.2 & 20.4 & 20.8 & 22.0 & 22.8 & 22.8 & 24.2 & 24.4 \\
guandu & 30 & 19.2 & 20.0 & 20.2 & 21.0 & 22.4 & 23.0 & 24.0 & 24.2
\end{tabular}




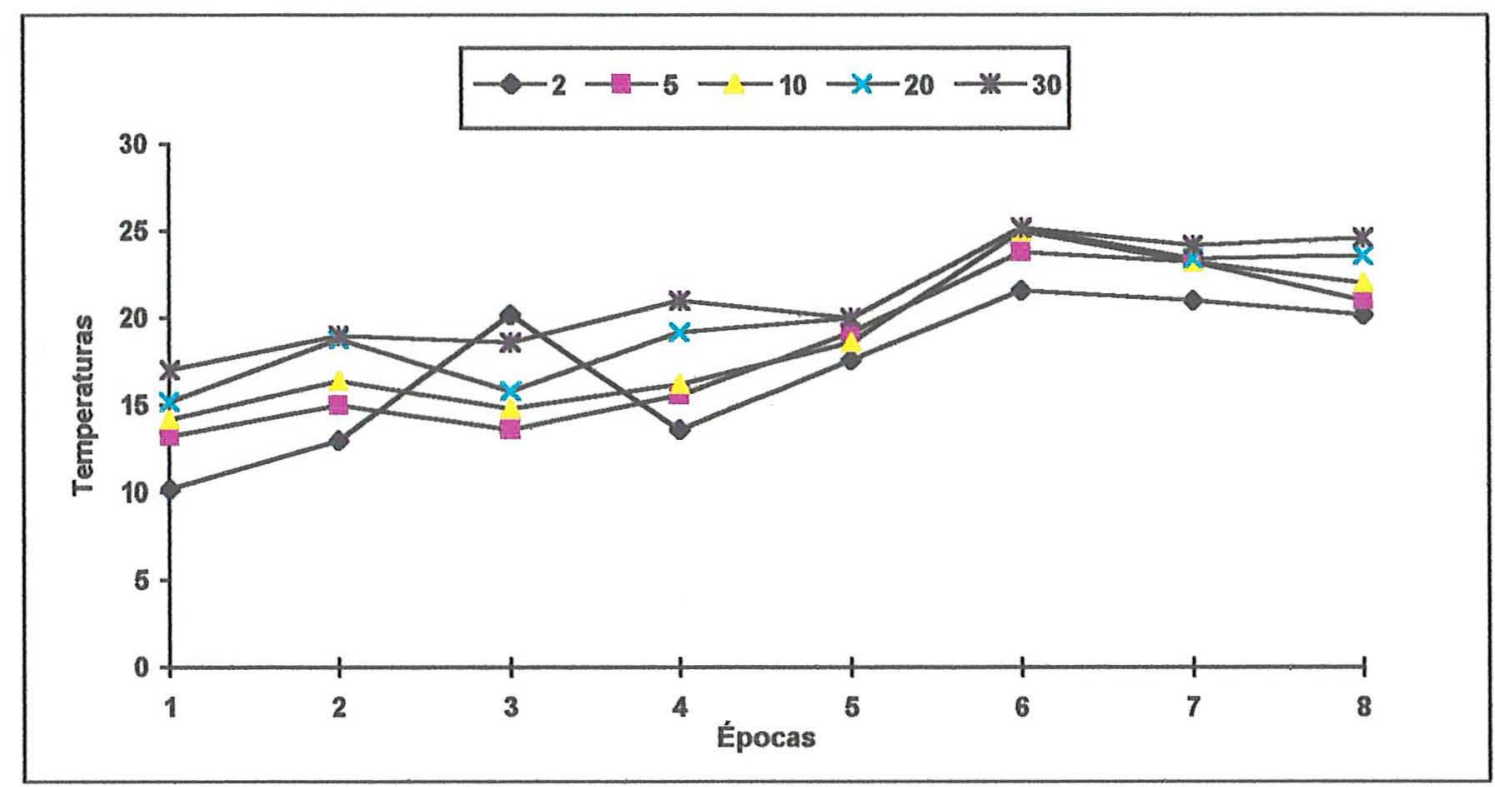

Figura 18. Evolução das temperaturas mínimas do solo nas diferentes profundidades para o tratamento testemunha (solo nu), durante os 8 períodos.

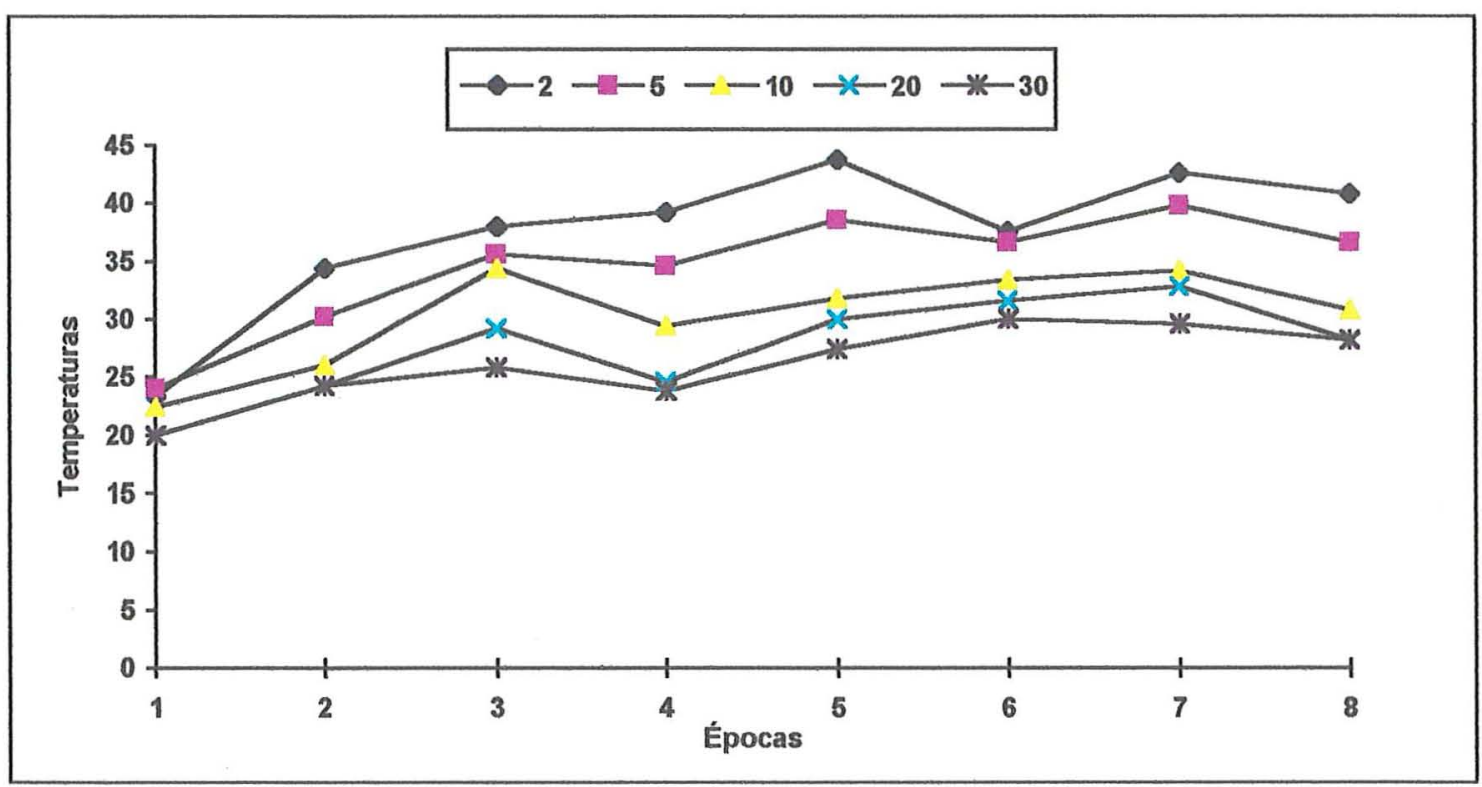

Figura 19. Evolução da temperatura máxima do solo nas diferentes profundidades para o tratamento testemunha. 
Tabela 31. Dados da temperatura mínima e máxima do solo para o tratamento testemunha (solo $\mathrm{nu}$ ), durante os $\mathbf{8}$ períodos.

Temperatura mínima do solo para o tratamento testemunha (solo nu)

\begin{tabular}{lccccccccc}
\hline tratam & Prof. & 1 & 2 & 3 & 4 & 5 & 6 & 7 & 8 \\
\hline testem. & 2 & 10.2 & 13.0 & 20.2 & 13.6 & 17.6 & 21.6 & 21.0 & 20.2 \\
testem. & 5 & 13.2 & 15.0 & 13.6 & 15.6 & 19.2 & 23.8 & 23.2 & 21.0 \\
testem. & 10 & 14.2 & 16.4 & 14.8 & 16.2 & 18.6 & 25.0 & 23.2 & 22.0 \\
testem. & 20 & 15.2 & 18.8 & 15.8 & 19.2 & 20.0 & 25.2 & 23.4 & 23.6 \\
testem. & 30 & 17.0 & 19.0 & 18.6 & 21.0 & 20.0 & 25.2 & 24.2 & 24.6 \\
\hline
\end{tabular}

Temperatura máxima do solo para o tratamento testemunha (solo nu)

\begin{tabular}{lccccccccc}
\hline tratam. & Prof. & 1 & 2 & 3 & 4 & 5 & 6 & 7 & 8 \\
\hline testem. & 2 & 23.4 & 34.4 & 38.0 & 39.2 & 43.8 & 37.6 & 42.6 & 40.8 \\
testem. & 5 & 24.0 & 30.2 & 35.6 & 34.6 & 38.6 & 36.6 & 39.8 & 36.6 \\
testem. & 10 & 22.4 & 26.0 & 34.4 & 29.4 & 31.8 & 33.4 & 34.2 & 30.8 \\
testem. & 20 & 20.0 & 24.2 & 29.2 & 24.6 & 30.0 & 31.6 & 32.8 & 28.2 \\
testem. & 30 & 20.0 & 24.2 & 25.8 & 23.8 & 27.4 & 30.0 & 29.6 & 28.2 \\
\hline
\end{tabular}




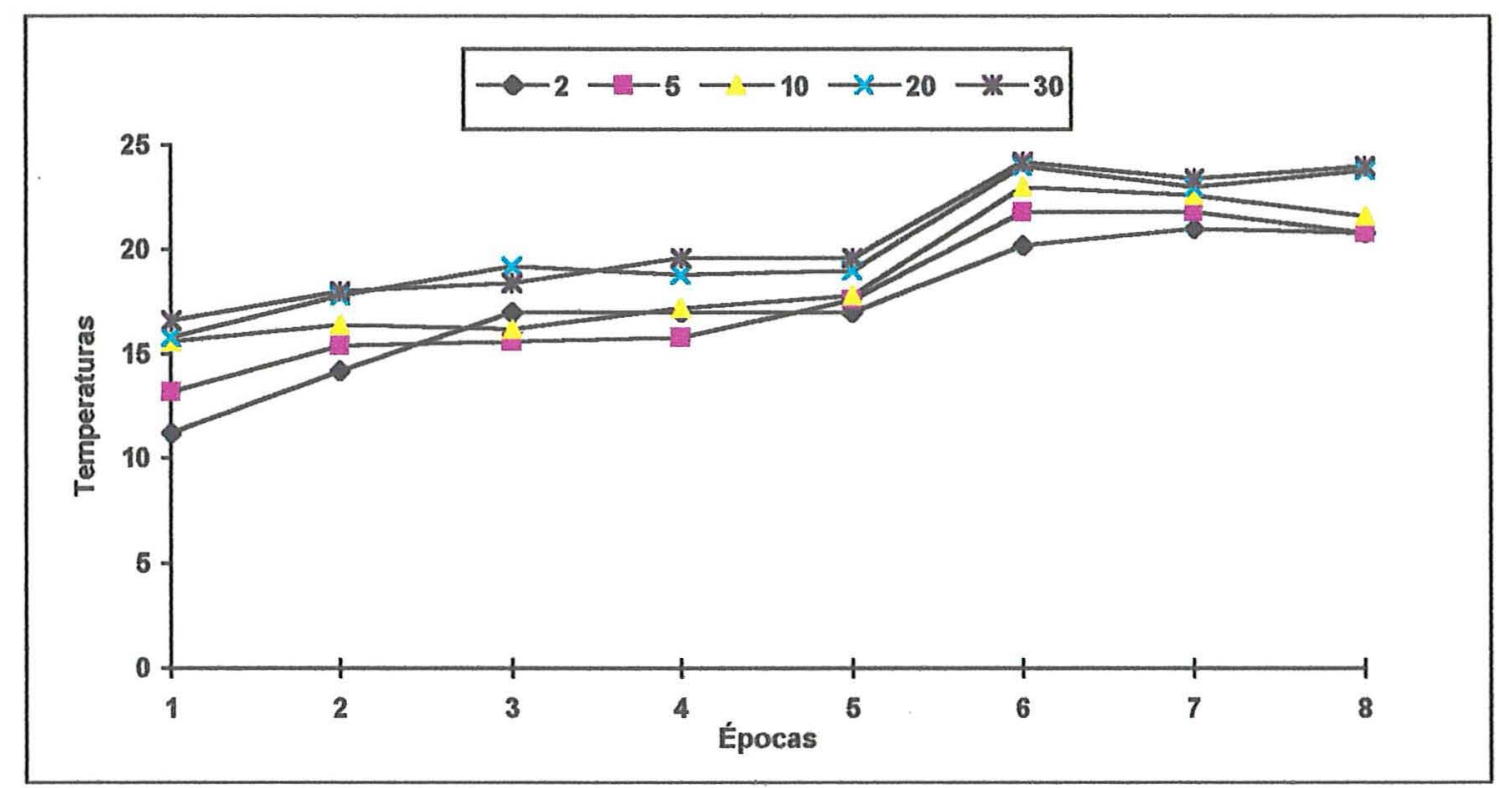

Figura 20. Evolução das temperaturas mínimas do solo nas diferentes profundidades para o tratamento $\mathrm{CMG}$ (cobertura morta de guandu), durante os 8 períodos.

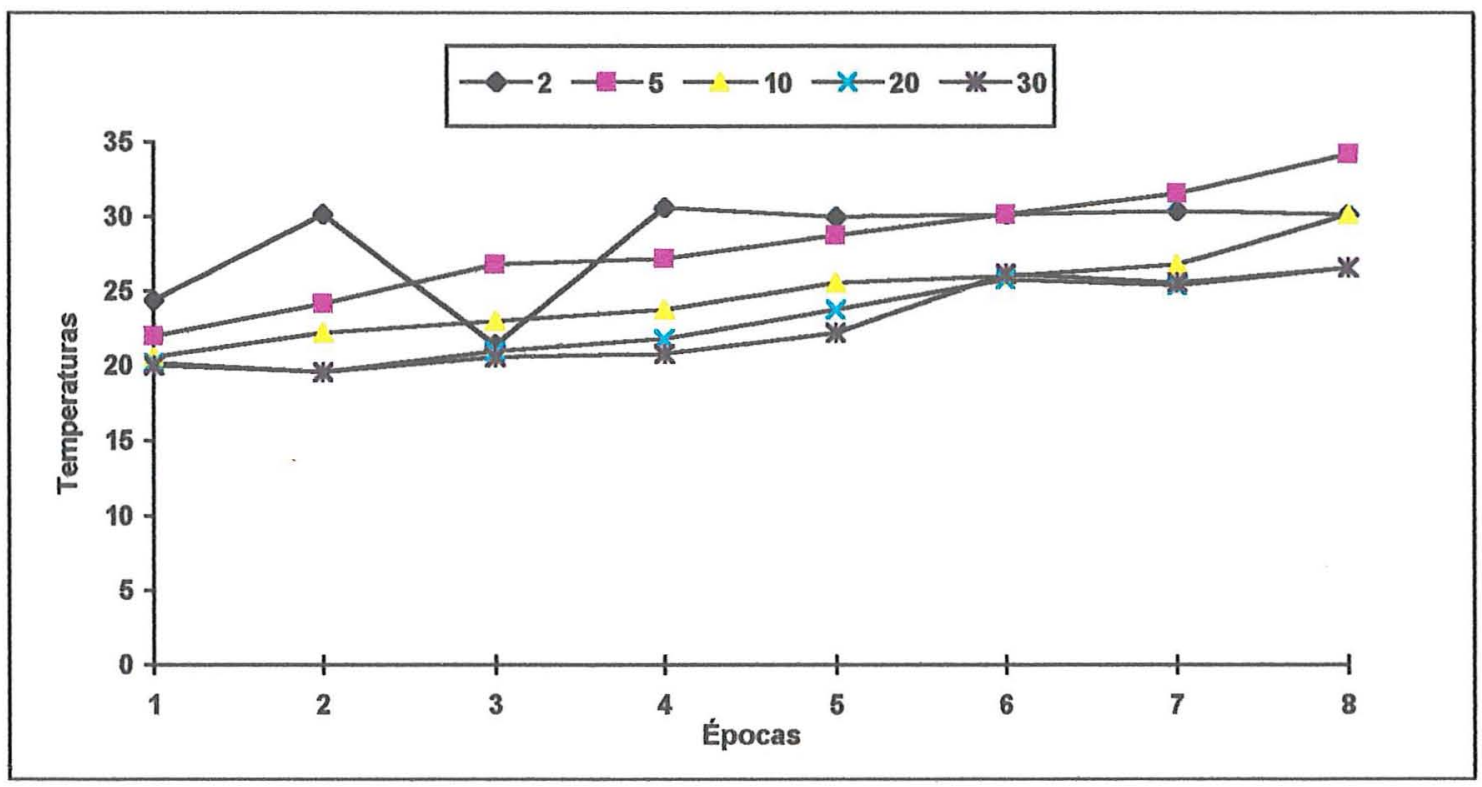

Figura 21. Evolução da temperatura máxima do solo nas diferentes profundidades para o tratamento CMG (cobertura morta de guandu) durante os 8 períodos. 
Tabela 32. Dados da temperatura mínima e máxima do solo para o tratamento CMG (cobertura morta de guandu) durante os 8 períodos.

Temperatura mínima do solo para o tratamento CMG (cobertura morta de guandu)

\begin{tabular}{lccccccccc}
\hline tratam. & Prof . & 1 & 2 & 3 & 4 & 5 & 6 & 7 & 8 \\
\hline CMG & 2 & 11.2 & 14.2 & 17.0 & 17.0 & 17.0 & 20.2 & 21.0 & 20.8 \\
CMG & 5 & 13.2 & 15.4 & 15.6 & 15.8 & 17.6 & 21.8 & 21.8 & 20.8 \\
CMG & 10 & 15.6 & 16.4 & 16.2 & 17.2 & 17.8 & 23.0 & 22.6 & 21.6 \\
CMG & 20 & 15.8 & 17.8 & 19.2 & 18.8 & 19.0 & 24.0 & 23.0 & 23.8 \\
CMG & 30 & 16.6 & 18.0 & 18.4 & 19.6 & 19.6 & 24.2 & 23.4 & 24.0 \\
\hline
\end{tabular}

Temperatura máxima do solo para o tratamento CMG (cobertura morta de guandu)

\begin{tabular}{llllllllll}
\hline tratam. & Prof. & 1 & 2 & 3 & 4 & 5 & 6 & 7 & 8
\end{tabular}

\begin{tabular}{lccccccccc}
\hline CMG & 2 & 24.4 & 30.2 & 21.4 & 30.6 & 30.0 & 30.2 & 30.4 & 30.2 \\
CMG & 5 & 22.0 & 24.2 & 26.8 & 27.2 & 28.8 & 30.2 & 31.6 & 34.2 \\
CMG & 10 & 20.6 & 22.2 & 23.0 & 23.8 & 25.6 & 26.0 & 26.8 & 30.2 \\
CMG & 20 & 20.2 & 19.6 & 21.0 & 21.8 & 23.8 & 25.8 & 25.4 & 26.6 \\
CMG & 30 & 20.0 & 19.6 & 20.6 & 20.8 & 22.2 & 26.2 & 25.6 & 26.6 \\
\hline
\end{tabular}




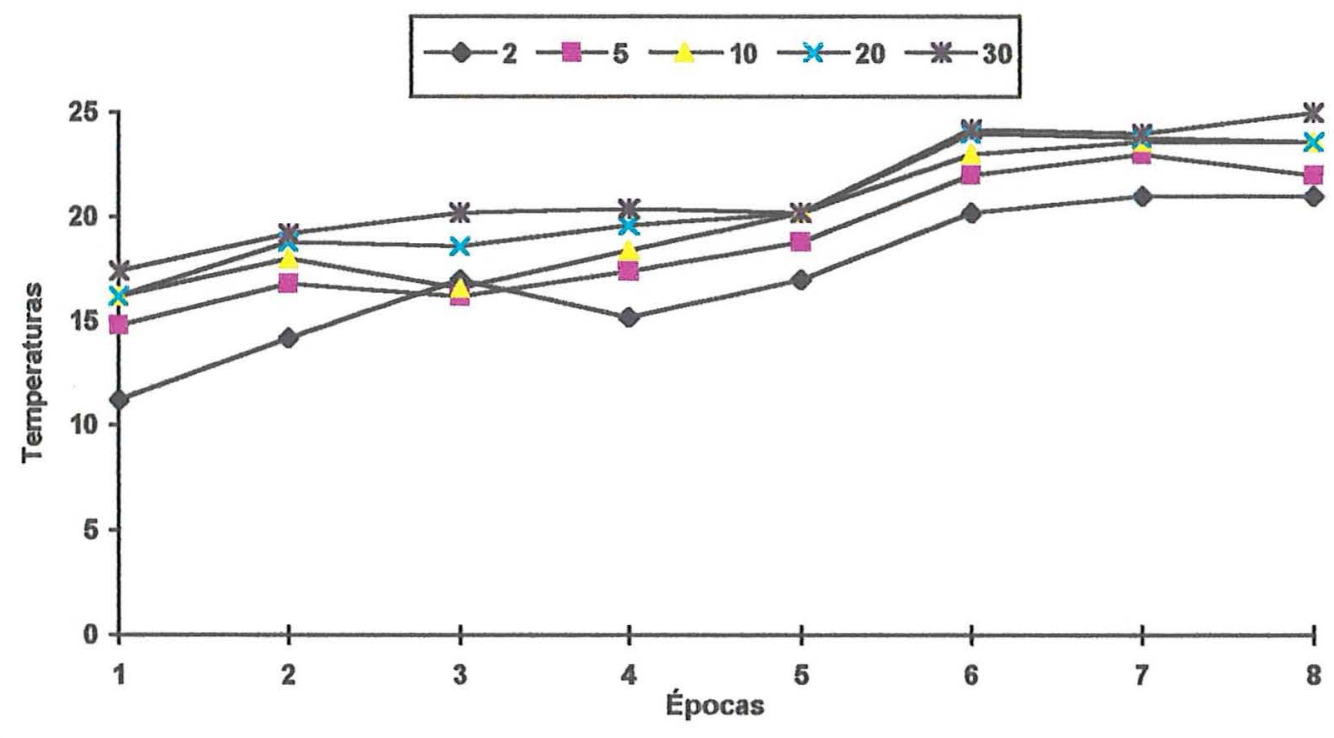

Figura 22. Evolução das temperaturas mínimas do solo nas diferentes profundidades para o tratamento CMM (cobertura morta de mucuna-preta), durante os 8 períodos.

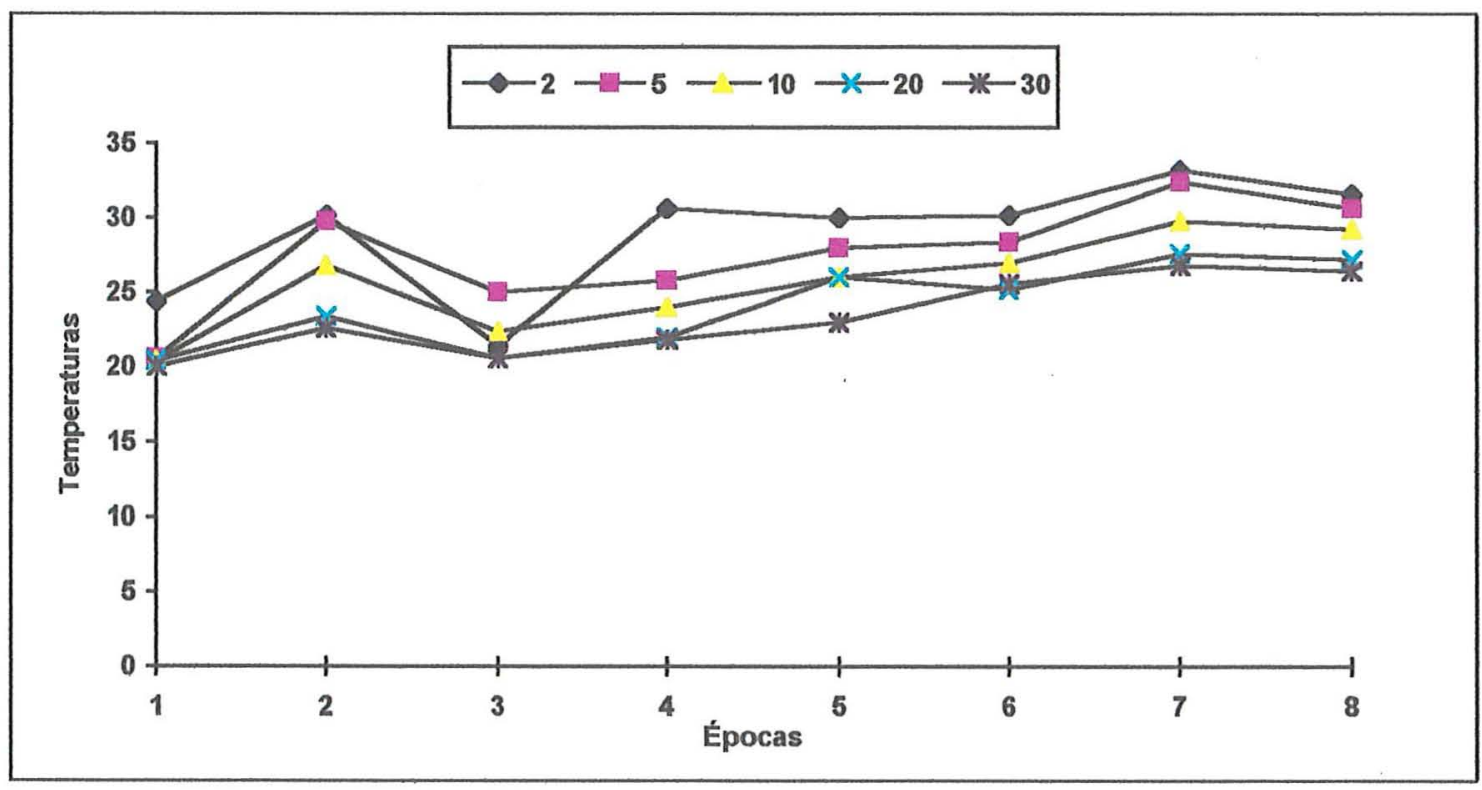

Figura 23. Evolução das temperaturas máximas do solo nas diferentes profundidades para o tratamento CMM (cobertura morta de mucuna-preta) durante os 8 períodos. 
Tabela 33. Dados da temperatura mínima e máxima do solo para o tratamento CMM (cobertura morta de mucuna-preta), durante os 8 períodos.

Temperatura mínima do solo para o tratamento CMM (cobertura morta de mucuna-preta)

\begin{tabular}{lccccccccc}
\hline Tratam. & Prof. & 1 & 2 & 3 & 4 & 5 & 6 & 7 & 8 \\
\hline $\mathrm{CMM}$ & 2 & 11.2 & 14.2 & 17.0 & 15.2 & 27.0 & 20.2 & 21.0 & 21.0 \\
$\mathrm{CMM}$ & 5 & 14.8 & 16.8 & 16.2 & 17.4 & 18.8 & 22.0 & 23.0 & 22.0 \\
$\mathrm{CMM}$ & 10 & 16.2 & 18.0 & 16.6 & 18.4 & 20.2 & 23.0 & 23.6 & 23.6 \\
$\mathrm{CMM}$ & 20 & 16.2 & 18.8 & 18.6 & 19.6 & 20.2 & 24.0 & 23.8 & 23.6 \\
$\mathrm{CMM}$ & 30 & 17.4 & 19.2 & 20.2 & 20.4 & 20.2 & 24.2 & 24.0 & 25.0 \\
\hline
\end{tabular}

Temperatura máxima do solo para o tratamento CMM ( cobertura morta de mucuna-preta)

\begin{tabular}{llllllllll}
\hline tratam. & Prof. & 1 & 2 & 3 & 4 & 5 & 6 & 7 & 8
\end{tabular}

\begin{tabular}{llllllllll}
\hline CMM & 2 & 24.4 & 30.2 & 21.4 & 30.6 & 30.0 & 30.2 & 33.2 & 31.6
\end{tabular}

$\begin{array}{llllllllll}\text { CMM } & 5 & 20.6 & 29.8 & 25.0 & 25.8 & 28.0 & 28.4 & 32.4 & 30.6\end{array}$

$\begin{array}{llllllllll}\mathrm{CMM} & 10 & 20.4 & 26.8 & 22.4 & 24.0 & 26.0 & 27.0 & 29.8 & 29.2\end{array}$

$\begin{array}{llllllllll}\mathrm{CMM} & 20 & 20.4 & 23.4 & 20.6 & 22.0 & 26.0 & 25.2 & 27.6 & 27.2\end{array}$

$\begin{array}{llllllllll}\text { CMM } & 30 & 20.0 & 22.6 & 20.6 & 21.8 & 23.0 & 25.6 & 26.8 & 26.4\end{array}$ 


\subsection{Observações gerais}

Foi observado nesse período do experimento que a cobertura vegetal do solo com leguminosas foi benéfica, evitando oscilações excessivas da temperatura . Houve um pequeno acúmulo de matéria orgânica, evitando também danos por ocasião de chuvas intensas.

No solo nu (testemunha) o deslocamento superficial de partículas provocou arrastamento de solo, documentado na figura 1.

Embora obtidos esses resultados favoráveis, necessita-se de mais pesquisas ao longo do tempo durante o decorrer do desenvolvimento do seringal jovem. 


\section{CONCLUSÕES}

Os resultados obtidos nas condições em que foi realizado o experimento, nos permite concluir que:

1. O emprego da cobertura permanente de guandu evita a erosão e o aquecimento excessivo do solo.

2. O emprego da cobertura permanente de guandu reduz o nitrogênio mineral e o teor de água a $10 \mathrm{~cm}$ de profundidade do solo .

3. A cobertura morta de mucuna-preta mantém o mesmo valor de nitrogênio mineral no solo, evita o aquecimento excessivo e a erosão do solo.

4. A cobertura morta de mucuna-preta reduz o teor de umidade nas duas profundidades do solo. 


\section{REFERÊNCIAS BIBLIOGRÁFICAS}

AMBROSANO, E.J. Dinâmica do nitrogênio dos adubos verdes, crotalária juncea (Crotalaria juncea) e mucuna-preta (Mucuna aterrima), em dois solos cultivados com milho. Piracicaba, 1995. 83p. Tese (Doutorado) - Escola Superior de Agricultura "Luiz de Queiroz", Universidade de São Paulo.

ANUÁRIO ESTATISTICO: Mercado de Borracha, v.8/10, p.62-66, 1995.

BAVEL, C.H.M. Soil temperature and crop growth. In: HILLEL,D.(Ed.) Optimizing the soil physical environment toward greater crop yields. New York: Academic Press, 1972. p.23-33.

BERNARDES, M.S.; CASTRO, P.R.C.; MARTINS, A.N. Fatores ligados à escolha do sistema de explotação. In: BERNARDES, M.S. (Ed.) Sangria da seringueira. Piracicaba: ESALQ, Dept ${ }^{\circ}$. de Agricultura, 1990. p.45-58. 
BERNARDES, M.S.; VEIGA, A.S.; FONSECA FILHO, H. Mercado brasileiro de borracha natural. In: BERNARDES, M.S. (Ed.) Explotação da seringueira. Piracicaba: FEALQ, 1990. p.179-206.

BRAGAGNOLO, N. Efeito da cobertura do solo por resíduos de culturas sobre a temperatura e umidade do solo, germinação e crescimento do milho. Porto Alegre, 1986. 119p. Dissertação (Mestrado) - Faculdade de Agronomia, Universidade Federal do Rio Grande do Sul.

BRAGAGNOLO, N.; MIELNICZUK, J. Cobertura do solo por palha de trigo seu relacionamento com a temperatura e umidade do solo. Revista Brasileira de Ciência do Solo, v.14, p.374-96, 1990.

BREMNER, J.M. Total nitrogen. In: BLACK, C.A et al. (Ed.) Methods of soil analysis chemical and microbiological properties. Madison: American Society of Agronomy, 1965. p.1178. (ASA. Agronomy, 2).

BROADBENT, F. E. ; STOJANOVIC, B.F. The effect of parcial pressure of oxigen on some soil nitrogen transformations. Soil Science Society of American. Proceedings, n.16, p.359-363, 1952. 
BULISANI, E.A.; BRAGA, N.R. Mucuna-preta, In: PEDRO JÚNIOR, M.J.; BULISANI, E.A ; POMMER, C.V.; PASSOS, F.A ; GODOY, I.J; ARANHA, C. Instruções agrícolas para o Estado de São Paulo. Campinas: IAC, 1987. p.154. (IAC. Boletim, 200).

BULISANI, E.A.; BRAGA, N.R.; ROSTON, A.J. Utilização de leguminosas, como cobertura de solo em sistemas de adubação verde ou rotação de culturas. In: ENCONTRO PAULISTA DE PLANTIO DIRETO, 1. , Piracicaba, 1987. Piracicaba: FEALQ,1987. p.63-70.

CALEGARI, A Leguminosas para adubação verde de verão no Paraná. Londrina : IAPAR, 1995. 118p. (IAPAR. Circular,80).

CARDOSO, M. Produtividade de clones de seringueira no Planalto do Estado de São Paulo. Bragantia, v.32. p.9-11, 1973.

CARDOSO, M. Instruções para a cultura da seringueira. 3.ed. Campinas: IAC, 1989. 42p. (IAC. Boletim, 196).

CARDOSO,M.; GONÇALVES,P.S.; SÁES, L.A. Cobertura com leguminosas no cultivo da seringueira: seu efeito no crescimento e produção. O Agronômico, v.40, n.3 .p.220-223, 1988. 
CARNAUBA, T.T. ; ORTOLANI, A.A. Lesão do colo de mudas de abacateiro por temperatura elevada. Bragantia - v.25, p.XLV-XLIX, 1966.

CHANDAPILLAY, M.M. Studies of root systems of some cover plants. Journal of Rubber Research Institute of Malaysia, v.20, n.31, 1968.

COLOMBO, C.A.; GONÇALVES, P.S.; CARDOSO, M.; BOAVENTURA M.A.M.; MARTINS, A.L.M. Importância conservação e uso de germoplasma de Hevea ssp. O Agronômico, v.41, n.3 , p.214-225, 1989.

CONFORTO, E.C. Estado hídrico e alguns parâmetros fenológicos, anatômicos, biométricos e produtivos de três cultivares de seringueira (Hevea ssp) em Piracicaba, SP. Rio Claro, 1995. 192p. Tese (Doutorado) - Instituto de Biociências, Universidade Estadual Paulista de Rio Claro.

COSTA, A.L. ; GODOY, H. Contribuição para o conhecimento do clima do solo de Ribeirão Preto. Bragantia, v. 21, p. 689-742, 1962.

COSTA, J.D.; MEDRADO, M.J.S. Cobertura vegetal do solo na formação do seringal. In: SIMPÓSIO SOBRE A CULTURA DA SERINGUEIRA, 2., Piracicaba,1990. Anais. Piracicaba: ESALQ, Depart ${ }^{\circ}$. de Agricultura, 1990. p.13-38. 
CYCLE of nutrientes in rubber plantations. Planters'Bulletin, v.120, p.73-81, 1972.

DART, P.J.; MERCER, F.V. The effect of growth temperature, level of ammonium nitrate and ligth intensity on the growth and nodulation of cowpea (Vigna sinensis endl. Ex Hassak.) . Australian Journal of Agricultural Research , v.16, p.321-345, 1965.

DART, P.J.; DAY, J.M ; ISLAM, R.; DÖBEREINER, J. Symbiosis in tropical grain legumes some effects of temperature and composition of the temperature and the composition of the rooting medium. In: NUTMAN, P.S., (Ed.) Simbiotic nitrogen fixation in plants. Cambridge: Cambridge University Press, 1976. p.361-386. (International Biological Programme, 7).

DERPSCH, R.; SIDIRAS,N.; HEINZMANN, F.X. Efeito da adubação verde de inverno sobre a umidade e temperatura do solo e rendimentos de culturas de verão. In: CONGRESSO BRASILEIRO DE CIÊNCIAS DO SOLO, 19. Curitiba, 1983. Anais. Campinas: Sociedade Brasileira de Ciências do Solo, 1983. p.110.

DERPSCH, R.; SIDIRAS,N.; HEINZMANN, F.X. Manejo do solo com coberturas verdes de inverno. Pesquisa Agropecuária Brasileira, v.20, n.7, p.761-773, 1985 . 
DÖBEREINER, J. Potencial for nitrogen fixation in tropical legumes and grasses. In: DÖBEREINER, J.; BURRIS, R.H.; HOLLAENDER, A.; FRANCO, A.A.; NEYRA, C.A.; SCOTT, D.B. Limitations and potencials for biological nitrogen fixation in the tropics. New York: Plenum Press, 1978. p.13-24.

DÖBEREINER, J. ; ARONOVICH, S. Efeito da calagem e da temperatura no solo na fixação de nitrogênio de "Centrosema pubescens" Benth em solos com toxidez de manganês. Boletim Instituto de Pesquisa e Experimentação Agropecuária do Centro-Sul : Ministério da Agricultura. Rio de Janeiro . 1966.

DOLMAT, M.T. Role of legume covers. The effects on growth and yield. In: RUBBER RESEARCH INSTITUTE OF MALAYSIA. RRIM training manual rubber planting and nursey techiques. Kuala Lumpur, 1980. p. 149-157.

EPSTEIN, E. Mineral nutrition of plants: principles and perspectives. New York:John Wiley, 1972. 412p.

FRANCO, A.A. Contribution of the legume - Rhizobium symbiosis to the ecossystem and food production. In: DÖBEREINER, J.; BURRIS, R.H.; HOLLAENDER, A.; FRANCO, A.A.; NEYRA, C.A.; SCOTT, D.B. Limitations and potentials for biological nitrogen fixation in the tropics. New York: Plenum Press, 1978. p.65-74. 
FRANCO, A.A.; SOUTO, S.M. Contribuição da fixação biológica de $\mathrm{N}^{2}$ na adubação verde. In: ENCONTRO NACIONAL SOBRE ADUBAÇÃO VERDE, 1., Rio de Janeiro, 1983. Adubação verde no Brasil. Campinas: Fundação Cargill, 1984. p.199-215.

FRANCO, C.M. Influence of temperature on growth of coffee plant. São Paulo: International Basic Economic Cooperation Institute, 1958 . 24p. (Boletim, 16).

FRANCO, C.M. Lesão do colo do cafeeiro causada pelo calor. Bragantia, v.20, n.24, p.645-652. 1961.

FREITAS, J.R. Dinâmica do nitrogênio em um solo Terra Roxa Estruturada (TRE) tratado com matéria orgânica vegetal e sulfato de amônio enriquecidos com o isótopo ${ }^{15} \mathrm{~N}$. Piracicaba, 1984. 113p. Dissertação (Mestrado) - Escola Superior de Agricultura “Luiz de Queiroz”, Universidade de São Paulo.

HARIDA, G. Responses to fertilisers on growth and yield of rubber. In: RUBBER RESEARCH INSTITUTE OF MALAYSIA. RRIM training manual on soils, soil management and nutrition of Hevea. Malaysia: RRIM, 1979. p. $125-136$.

HAYNES, R.J. Influence of soil management practice on the orchard agroecosystem. Agro-Ecosystems, v.6, p.3-32, 1980. 
IGUE, K. Dinâmica da matéria orgânica e seus efeitos na propriedade do solo. In: ENCONTRO NACIONAL SOBRE ADUBAÇÃO VERDE, 1., Rio de Janeiro, 1983. Adubação verde no Brasil. Campinas: Fundação Cargill, 1984. p.232-267.

INSTITUT DE RESEARCHES SUR LE CAOUTCHOUC. Fiche des clones : description de comportement. Paris: IRCA/CIRAD, 1985. (Fiche Technique $\mathrm{s} / \mathbf{n})$.

KOHL, D.H.; SHEARER, G.B.; COMMONER, B. Fertilizer nitrogen contribuition to nitrate in surface water, in a cornbelt watershed . Science, v.174, p.1331-1334, 1971.

LADD, J.N.; JACKON, R.B. Biochemistry of ammonification. In: STEVENSON, F.J., (Ed.) Nitrogen in agricultural soils. Madison: American Society of Agronomy, 1983. p.173-222.

LAL, R. Role of mulching techniques in tropical soil and water management Ibadan: International Institute of Tropical Agriculture, 1974a. 37p. (Technical Bulletin,1).

LAL,R. Soil temperature, soil moisture and maize yield from mulched and unmulched tropical soils. Plant and Soil, v.40, p.129-443, 1979. 
LONERAGAN, J.F. The legume-Rhizobium symbiosis. The Journal of the Australian Institute of Agricultural Science, v. , p.26-31, Mar. 1960.

LOPES, A.S. Manual de fertilidade do solo. Piracicaba: ANDA/POTAFOS, 1989. $155 \mathrm{p}$.

MAINSTONE, B.J. Residual effects of ground cover and nitrogen fertilization of Hevea pror to tapping. Journal of Rubber Research Institute of Malaysia, v.21, n.2, p.113-125, 1969.

MARTINS, NA. Sistemas de explotação em seringueira (Hevea brasiliensis Muell.Arg. cv.GT1) na região de Piracicaba. Piracicaba, 1995. 107p. Dissertação (Mestrado) - Escola Superior de Agricultura "Luiz de Queiroz", Universidade de São Paulo.

MASCARENHAS, H.A.A.; TANAKA, R.T.; COSTA, A.A.; ROSA, F.V.; COSTA, V.F. Efeito residual das leguminosas sobre o rendimento físico e econômico da cana-planta. Campinas: IAC, 1994. 15p. (IAC. Boletim Científico,32).

MEDCALF, J.C. Estudos preliminares sobre aplicação de cobertura morta em cafeeiros novos no Brasil. São Paulo: International Basic Economic Cooperation Institute, 1956. 59p. (Boletim,12). 
MEDRADO, M. J. S.; COSTA, J.D. Clones de seringueira para a região do Planalto Paulista. Piracicaba: PCAP/USP, 1990. 12p. (Informativo Técnico, 9).

MELLO, F.A.F.; BRASIL SOBRINHO, M.O.C. Efeitos da incorporação de resíduos de mucuna-preta, Crotalária juncea L. e feijão baiano. I. Influência sobre a produção de arroz. Revista de Agricultura, v.35, n.1, p.33-40, 1960.

MIYASAKA, S. Histórico do estudo de adubação verde, leguminosas viáveis. In: ENCONTRO NACIONAL SOBRE ADUBAÇÃO VERDE, 1., Rio de Janeiro, 1983. Adubação verde no Brasil. Campinas: Fundação Cargill, 1984. p.64-123.

MOROTE, C.G.B.;VIDOR,C.; MENDES, N.G. Alterações na temperatura do solo pela cobertura morta e irrigação. Revista Brasileira de Ciência do Solo, v. 14, p.81-84, 1990.

MURAOKA, T. Utilização de técnicas nucleares nos estudos de adubação verde. In: ENCONTRO NACIONAL SOBRE ADUBAÇÃO VERDE, 1., Rio de Janeiro, 1983. Adubação verde no Brasil. Campinas: Fundação Cargill, 1984. p.330. 
MYERS, R.J.K.; CAMPBEL, C.A ; WEIER, K.L. Qantitative relationship between net nitrogen mineralization and moisture content of soils. Canadian Journal of Soil Science, v.62, p.111-124, 1982.

NYE, P.H.; TINKER,P.B. Solute movement in the soil-root system. Oxford: Blackwel, 1977. 342p .

ORTOLANI, A.A. Agroclimatologia e cultivo da seringueira. In: SIMPÓSIO SOBRE A CULTURA DA SERINGUEIRA NO ESTADO DE SÃO PAULO, Piracicaba, 1986. Anais. Campinas: Fundação Cargill, 1986. p.11-32.

ORTOLANI, A.A. Efeito das temperaturas extremas no desenvolvimento e produção da seringueira. In: SIMPÓSIO DA CULTURA DA SERINGUEIRA, 2., Piracicaba, 1987. Anais. Piracicaba: ESALQ, Depart ${ }^{\circ}$ de Agricultura, 1987. p. 1-12.

POTTY, S.N.; KOTHANDARAMAN, R.; MATHEW, M. Field upkeep. In: RADRAKRISHNA PILLAY, P. N. (Ed.) Handbook of natural rubber production in India. Kottayanam: Rubber Research Institute of India, 1980. cap. 9, p.135-155.

PRIMAVESI, A. Agricultura sustentável. São Paulo: Nobel, 1992 . 142p. 
PUSHPARAJAH, E.; CHELLAPAH, K. Manuring of rubber in relation to covers. Journal of the Rubber Research Institute of Malaysia,v.21, p.126$130,1969$.

RUBBER RESEARCH INSTITUTE OF MALAYSIA. Cover and fertilisers for imature Rubber. Planters' Bulletin . Kuala Lumpur, v. 89 p. 66-72, 1967.

SALGADO, J.S.; MARQUES, P.C. Seleção de leguminosas em consórcio com plantio de seringueira. Cariacica: EMCAPA, 1984. 6p. (EMCAPA. Pesquisa em Andamento,22).

SETHURAJ, M.R. Physiology of growth and yield in Hevea brasiliensis. In: INTERNATIONAL RUBBER CONFERENCE, Kuala Lumpur, 1985. Proceedings. Kuala Lumpur:RRIM, 1985. p.1-16.

SICHMANN, W. A cultura da soja. In: FUNDAÇÃO CARGILL. A soja no Brasil Central. Campinas, 1977. p.219-261.

SIDIRAS, N.; PAVAN, M.A Influência do manejo do solo no seu nível de fertilidade. Revista Brasileira de Ciência do Solo, v.9, n.3, p.249-254, 1985.

SIDIRAS, N.; PAVAN, M.A Influência do sistema de manejo na temperatura do solo. Revista Brasileira de Ciência do Solo, v.10, n.3 , p.181-184, 1986. 
SIDIRAS, N.; DERPSCH, R.; HEINZMAN, F.X. Influência da adubação verde de inverno e seu efeito residual sobre o rendimento nas culturas de verão, em Latossolo Roxo distrófico. Plantio Direto, v.9, n.2, p.4-5, 1984.

SOONG, N.K.; YAP, W.C. Effect of cover management on physical properties of rubber growing soil. Journal of the Rubber Research Institute of Malaysia, v.24, p.145-147, 1976.

STANFORD, G.; EPSTEIN, E. Nitrogen mineralization-water relations in soils. Soil Science Society of America Proceedings, v.38, p.103-107, 1974.

TAN, K.H.; PUSPARAJAH, E.; SHEPHERD, R.; TOCH, C.H. Calopogonium caeruleum a shade tolerant leguminous cover for rubber. In: RUBBER RESEARCH INSTITUTE OF MALAYSIA PLANTERS'CONFERENCE, Kuala Lumpur, 1976. Proceedings. Kuala Lumpur, 1976. p.45-62.

TERMAN, G.C. Volatilization losses of nitrogen as ammonia from surfaceapplied fertilizers, organic amendments, and crop residues. Advances in Agronomy, v. 31, p.189-223, 1979.

UNGER, P.W.; McCALLA, T.M. Conservation tillage systems. Advances in Agronomy, v.33, p.39-42, 1980. 
URQUIAGA, C.S. Dinâmica do nitrogênio no sistema solo-planta na cultura do feijão ( Phaseolus vulgaris, L.), cultivar carioca. Piracicaba, 1982. 154p. Tese (Doutorado) - Escola Superior de Agricultura "Luiz de Queiroz", Universidade de São Paulo.

VOSS, M.; SIDIRAS, N. Nodulação da soja em plantio direto em comparação com plantio convencional. Pesquisa Agropecuária Brasileira, v.20, p.775$82,1985$.

WATSON, G.A. Nitrogen fixation by Centrosema pubescens. Journal of the Rubber Research Institute of Malaysia, v.15, n.3, p.168-174, 1957.

WATSON, G.A.; WONG, P.W.; NARAYANAN, R. Effects of cover plants soil nutrient status and growt of Hevea III. A comparison of leguminous creeps with grass and Mikania cordata. Journal of the Rubber Research Institute of Malaysia, v. 18, n.2, p.80-91, 1964.

WUTKE, E.B. Caracterização fenológica e avaliação agronômica de genótipos de guandu (Cajanus cajan (L) Millsp.). Piracicaba, 1987. 164p. Dissertação (Mestrado) - Escola Superior de Agricultura "Luiz de Queiroz", Universidade de São Paulo. 
WUTKE, E.B. Adubação verde: manejo da fitomassa e espécies utilizadas no Estado de São Paulo. In: CURSO SOBRE ADUBAÇÃO VERDE NO INSTITUTO AGRONÔMICO,1., Campinas, 1993. Campinas: IAC,1993. p.17-22. (IAC Documentos, 35).

YOGARATNAM, N.; SULLAIMAN, H.; KARUNARATNA, A.D.M.; PERRIES, K.S.A.C. Management of cover under Hevea in Sri Lanka. Journal of the Rubber Research Institute of Sri Lanka, v.54,n.2, p.291298, 1977. 